Международная Научно-Исследовательская Федерация «Общественная наука»

\title{
НАУКА РОССИИ: ЦЕЛИ И ЗАДАЧИ
}

\author{
Сборник научных трудов \\ по материалам \\ IV международной научной конференции
}

10 августа 2017 г.

Часть 1

\section{JoURNAL_RU}

Екатеринбург 2017 
УДК 001.1

ББК 60

Наука России: Цели и задачи. Сборник научных трудов, по материалам IV международной научно-практической конференции 10 августа 2017 г. Часть 1 Изд. НИЦ «Л-Журнал», 2017. - 68c.

\section{SPLN 001-000001-0171-SR}

DOI 10.18411/sr-10-08-2017-1

IDSP 000001:sr-10-08-2017-1

В сборнике научных трудов собраны материалы из различных областей научных знаний. В данном издании приведены все материалы, которые были присланы на IV международную научно-практическую конференцию Наука России: Цели и задачи

Сборник предназначен для научных работников, преподавателей, аспирантов и студентов.

Все материалы, размещенные в сборнике, опубликованы в авторском варианте. Редакция не вносила коррективы в научные статьи. Ответственность за информацию, размещенную в материалах на всеобщее обозрение, несут их авторы.

Информация об опубликованных статьях будет передана в систему Российского индекса научного цитирования (РИНЦ)

Электронная версия сборника доступна на сайте научноиздательского центра «Л-Журнал». Сайт центра: science-russia.ru

УДК 001.1

ББК 60 


\section{Содержание}

РАЗДЕЛ І. ПЕДАГОГИКА

Голованов С.А. Фитнес для коррекции здоровья мужчин больных сахарным диабетом5

Касьяненко А.А. Проблемы профессиональной и личностной готовности педагогов к процессу интеграции детей с ограниченными возможностями здоровья в

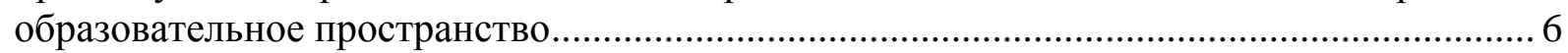

Киселева Е.В. Формирование основных движений младших дошкольников через организацию подвижных игр

РАЗДЕЛ ІІ. ПСИОЛОГИЯ

Богослова Е.Г., Сюкиев Д.Н. Сущностно-содержательная характеристика Я концепции личности

РАЗДЕЛ III. ЭКОНОМИКА

Ермакова Г.А. Формирование понятия «интеллектуальный капитал» организации представителями различных экономических школ ......................................................... 17

Жамлиханова Л.3. Деятельность Центрального банка Российской Федерации 19

Ильяшенко В.В. Влияние валютного курса рубля на инфляционные процессы в российской экономике

Харитонов А.В. Роль личных подсобных хозяйств в устойчивом развитии сельских территорий: региональный аспект.

РАЗДЕЛ IV. ЮРИСПРУ ДЕНЦИЯ 30

Деманова С.В. Гуманитарное образование иностранных граждан в Российской Федерации: проблемы реализации 30

Кажибаева Г.Е. Юридические определения коррупции, ее виды и формы 34

Палий А.Ю. Научно-теоретический анализ противоречий о целях деятельности организованных преступных сообществ, содержащихся в действующем уголовном законодательстве, и пути их преодоления: по материалам Республики Крым...... 40

Пучкова В.В. Конституционная обязанность граждан о соблюдении законодательства в сфере здравоохранения .... 45 
Андреева Е.Г. Олицетворяющая метафора в научном тексте (сопоставление английского и русского языков) 50

Гулиева Г.О темпорально - метафорических моделях на азербайджанском и английском языках. .54

Исламова А.К. Стратегия глобализации художественного пространства в романе К. Уилсона «Башня 60

Кирдеева А.М. Семантика и функционирование глаголов восприятия в современных англоязычных художественных текстах 65 


\section{РАЗДЕЛ І. ПЕДАГОГИКА}

\section{Голованов С.А. \\ Фитнес для коррекции здоровья мужчин больных сахарным диабетом}

doi: 10.18411/sr-10-08-2017-01

idsp: 000001:sr-10-08-2017-01

Проблема лечения или/и коррекции состояния больных сахарным диабетом приобрела актуальность в планетарном масштабе, согласно данным Всемирной Организации Здравоохранения. При этом, аудитория мужчин в возрасте 35-45 лет является основной и распространенной в проявлениях рецидивных состояний диабета. Это и определило цель настоящего исследования - разработка и апробация тренировочной методики в условиях аэробных физических нагрузок для больных сахарным диабетом мужчин.

Все исследования проводились на базе фитнес клубе премиум класса «Svelte» в Москве. Общий срок наблюдений составлял 6 месяцев в году.

Группа испытуемых добровольцев, состояла из 14 мужчин в возрасте 35-45 лет, болеющих диабетом 2 типа в пределах 3-8 лет и получала для лечения только таблетированные препараты, способствующие понижению уровня сахара в крови. При этом, несмотря на лечение, уровень сахара крови у испытуемых был несколько повышенным.

Подготовительный этап тренировки занимал по времени 15 минут и состоял из двух частей: общая разминка и специальная. Занятие начиналась с разминки на беговой дорожке или велосипеде в зависимости от особенностей и ограничений опорно двигательного аппарата (ОДА). Затем - гимнастика на все группы мышц в течение 5 мин.

Основной этап тренировки занимал 60 минут и состоял из двух частей. Первой частью основного этапа занятия являлась работа на тренажерах с незначительными свободными весами (легкие гантели, бодибары) и собственным весом. Все упражнения выполнялись друг за другом по кругу (круговая тренировка), в течение 30 мин. Было 3 круга, после каждого полноценный отдых в течение 5 мин до полного восстановления. Проводился постоянный контроль ЧСС занимающегося во время нагрузки и отдыха. Во время выполнения упражнений тренером и медицинским работником отслеживалась пульсовая зона ЧСС не более 140-145 уд./мин. Второй частью основного этапа занятия являлось выполнение аэробной тренировки в течение 30 мин. Она включала в себя работу на кардио - тренажере с заданной ЧСС (не более $40 \%$ от мах.), выше которой аэробную нагрузку не применяли. Заключительный этап тренировочного занятия - заминка, длившаяся 15 минут и включавшаяся в себя ходьбу на беговой дорожке или велосипеде в зависимости от особенностей ОДА. Выполнялись упражнения на расслабление с глубоким дыханием. Затем шли дыхательные упражнения и легкая растяжка. На этом этапе проводилось определение перспектив занятий для каждого тренирующегося.

Проведенные наблюдения показали, что применение тренировочных занятий в указанных режимах у больных сахарным диабетом 2 типа вызывает устойчивое снижение уровня сахара в крови, приводит его к норме.

Таким образом, результаты исследования доказывают возможность укрепления здоровья тренирующихся мужчин в возрасте 35-45 лет с наличием сахарного диабета 2 типа. Также доказывается эффективность занятий физической культурой с применением анализатора состава тела «TANITA». Полученные в ходе исследования материалы, существенно обогащают теорию и методику адаптивной физической культуры. Они пополняют теорию физической реабилитации путем обоснования структуры и содержания методики оздоровительных тренировок, обеспечивающей активизацию защитных сил организма у лиц с ослабленным здоровьем, позволяют расширить имеющиеся представления о необходимости в условиях оздоровительных тренировок. 


\section{Касьяненко А.А. \\ Проблемы профессиональной и личностной готовности педагогов к процессу интеграции детей с ограниченными возможностями здоровья в образовательное пространство}

Северо-Восточный государственный университет (Россия, Магадан)

doi: 10.18411/sr-10-08-2017-02

idsp: 000001:sr-10-08-2017-02

\section{Аннотация}

В статье рассматриваются основные проблемы профессиональной и личностной готовности педагогов к процессу интеграции детей с ОВЗ. Раскрываются такие понятия, как: интеграция, психологические барьеры. Указываются конкретные проблемы для успешных реализации профессиональных навыков. Делается вывод, что профессионально-личностная готовность педагога к работе с детьми с ограниченными возможностями здоровья предполагает сформированность целого комплекса качеств, которые основываются на личностных ресурсах.

Ключевые слова: дети с ограниченными возможностями здоровья, процесс интеграции, личностная готовность, психологические барьеры.

В последнее время много говорят об инклюзивном и интегрированном образовании. Всем известно, что в настоящее время много детей с ограниченными возможностями здоровья обучается в специальных школах. Но таких школ не много. Генеральная Ассамблея ООН в 1948 г. утвердила Всеобщую декларацию прав человека. Это пакет международных документов об экономических, социальных и культурных правах людей; основной международный кодекс поведения в области прав человека.

Всеобщая декларация прав человека гласит: «Каждый человек имеет право на образование. Образование должно быть бесплатным по меньшей мере в том, что касается начального и общего образования. Начальное образование должно быть обязательным. Механическое и профессиональное образование должно быть общедоступным, и высшее образование должно быть доступным для всех на основе способностей каждого. Образование должно быть направлено к полному развитию человеческой личности и к увеличению уважения к правам человека и основным свободам» (ст. 26, п. 1, 2).

Уже сегодня в школах проводится интегративное и инклюзивное обучение детей с ограниченными возможностями здоровья, но о полном его введении говорить ещё рано.

Интеграция-(в переводе с латинского языка) процесс воссоединения, объединения в целое ранее разрозненных частей и элементов. Интеграция как целостность и как процесс не сглаживает и не обеспечивает специфику дифференцированных функций, необходимых для жизнедеятельности целого (интеграции). (6)

Интеграция, как социально-педагогический феномен, насчитывает несколько столетий. Обращение к истории специального образования детей с ограниченными возможностями здоровья и обычных детей существует с тех времен, когда было признано их право на образование. В истории педагогики немало примеров попыток организации специального обучения детей с особыми образовательными потребностями и обычных детей. (1)

Одним из первых обосновал идею интегрированного обучения Л.С.Выготский. (1) Впоследствии, его идея реализовалась в практике.

Л.С. Выготский указывал на необходимость создания такой системы обучения, в которой ребенок с ограниченными возможностями здоровья не исключался бы из общества детей с нормальным развитием. «При всех достоинствах наша специальная 
школа отличается тем основным недостатком, что она замыкает своего воспитанника слепого, глухого, умственно отсталого ребенка - в узкий круг коллектива, создает замкнутый мир, в котором все приспособлено к дефекту, все фиксирует его внимание на своем недостатке и не вводит его в настоящую жизнь. Специальное образовательное учреждение вместо того, чтобы выводить из изолированного мира, развивает в нем навыки, которые ведут к еще большей изоляции и усиливают его сепаратизм». $(50,1)$ Таким образом, Выготский считал, что основными задачами воспитания ребенка с нарушениями развития являются его интеграция в жизнь и осуществление компенсации его недостатка каким- либо другим путем. Причем компенсацию он понимал не в биологическом, а в психологическом аспекте, так как считал, что воспитателю в работе с ребенком, имеющим дефекты развития, приходится иметь дело скорее не с биологическими факторами, а с их психологическими последствиями. Он считал, что ориентировка на нормальных детей должна служить исходной точкой пересмотра специального образования. (2)

Не мало важную роль в процессе интеграции играют педагог, от деятельности которого будет зависеть успешность и эффективность процесса в таких позициях, как:

- возможность овладения общим образовательным стандартом в предусмотренные для нормально развивающихся детей сроки;

- создание наиболее благоприятных условий для развития личности ребенка (физического, психологического, интеллектуального, нравственного развития);

- оказание ребенку адекватной и своевременной помощи в процессе адаптации;

- включение ребенка с ограниченными возможностями здоровья в образовательное пространство;

- помощь во взаимодействии, общении с окружением включенным в образовательное пространство.

Таким образом, деятельность педагога ориентирована на эффективную реализацию включения ребенка с ограниченными возможностями здоровья в среду образовательного учреждения. (5)

Конечно, готовность педагога для работы с детьми с ограниченными возможностями здоровья будет определяться не только уровнем академических знаний, но и эмоциональным принятием этого ребенка, т.е., отсутствием психологических барьеров.

Психологический барьер (от франц. bariere - преграда, препятствие) специфические психологические состояния личности, которые не позволяют ей занять активную позицию и реализовать тот или иной вид деятельности и общения.

Нами было проведено исследование на воспитателях детских садов и учителях начальных классов, имеющих опыт работы с детьми с ограниченными возможностями здоровья, при помощи метода фокус-группы, по результатам которого мы определили, что у каждого учителя, из числа опрошенных, присутствуют барьеры. Что не может не сказываться негативным образом на качестве работы.

Основные сложности в эмоциональном принятии заключаются в том, что:

- педагог, как правило, «не знает» как оценивать индивидуальные достижения ребенка, каким способом проверять знания;

- страх навредить, или сделать что-то не правильно;

- недостаток специальных знаний, позволяющий полноценно осуществлять профессиональные навыки в работе с детьми с ограниченными возможностями здоровья; 
Также, были указаны такие проблемы, возникающие при работы с детьми с ограниченными возможностями здоровья, мешающие их успешной интеграции и качественному выполнению профессиональных навыков, как быстрое эмоциональное выгорание в процессе работы с такими детьми, недостаточная оснащенность методическим материалом и инструментарием и сложности с рациональным использованием и распределением времени между детьми с нормой развития и детьми с ограниченными возможностями здоровья. В ситуации детей с сенсорными нарушениями отмечен коммуникативный барьер «непонимания».

Работа с особыми детьми требует значительной профессиональной и личностной подготовки. Важной составляюшей является обладание такими профессиональными качествами, как толерантность, милосердие, эмпатия, готовность помочь,высокий уровень самоконтроля и саморегуляции, доброжелательность, умение наблюдать.

Милосердие - одно из существенных выражений гуманности. В понятии милосердия включены духовно-эмоциональный (переживание чужой боли как своей) и конкретно-практический (порыв к реальной помощи) аспекты. Милосердие употребляется по отношению к людям, нуждающимся в помощи (инвалидам, больным, престарелым и др.) и отражает готовность помочь нуждающимся и саму помощь. (7)

Эмпатия - важное профессиональное качество педагога, работающего с детьми с ограниченными возможностями здоровья, Она предполагает понимание ребенка, сочувствие ему, умение увидеть ситуацию его глазами, встать на его точку зрения. Эмпатия тесно связана с феноменом принятия, под которым подразумевается теплое эмоциональное отношение со стороны окружающих к ребенку с ограниченными возможностями здоровья. (7)

Толерантность включает терпимость, устойчивость к стрессу, неопределенности, конфликтам, поведенческим отклонениям, агрессивному поведению, к нарушению норм и границ. Способность понять, признать и принять индивидуальность ребенка, видя в нем носителя иных ценностей, мировоззрения и логики мышления, форм поведения и особенности внешности. (3)

Подготовка и переподготовка педагогов для реализации инклюзивного образования и процесса интеграции детей с ограниченными возможностями здоровьяв нашем регионе, в основном направлена на формирование знаний об особенностях детей и подростков с нарушениями развития и учета их в педагогическом процессе. При этом значительно меньше внимания обращается на профессионально-личностную готовность педагога к работе с детьми с ограниченными возможностями здоровья.

В идеале, педагог, работающий с детьми с ограниченными возможностями здоровья, должен обладать высоким уровнем регуляции своей деятельности, контролировать себя в стрессовых ситуациях, быстро и уверенно реагировать на изменение обстоятельств и принимать решения. Ему необходимо иметь в своем арсенале умения, позволяющие справляться с негативными эмоциями, навыки релаксации, умение владеть собой, способность адаптироваться в трудных, неожиданных ситуациях. Самообладание педагога, его уравновешенность, эмоциональная устойчивость позволят предупредить конфликтные ситуации в отношениях между детьми, между детьми и педагогом, что имеет особую значимость для правильной организации учебновоспитательного процесса. (7)

Таким образом, профессионально-личностная готовность педагога к работе с детьми с ограниченными возможностями здоровья предполагает сформированность целого комплекса качеств, которые основываются на личностных ресурсах. Не каждый педагог, работающий в общеобразовательном учреждении с нормально развивающимися 
детьми, способен к работе с ребенком, имеющим ограниченные возможности здоровья. (7)

$$
* * *
$$

1. Выготский Л.С. Собрание сочинений в шести томах: том 5. Основы дефектологии/ Л.С. Выготский М.: Книга по требованию, 2012. - 368 с.

2. Выготский Л.С. «Проблема культурного развития ребенка» //Вестник МГУ. Серия 14. Психология. 1991. №4. - C.5-18.

3. Клепцова Е.Ю. Психология и педагогика толерантности: учебн.пособие / Е.Ю. Клепцова. - М.: Академ.проект, 2004. - 176c.

4. Макоедова Г.В., Т.А. Савченко Социализация детей с ограничеснными возможностями здоровья: учебн. пособие / Г.В. Макоедова, Т.А. Савченко. - Магадан: СВГУ, 2013.-221с.

5. Назарова Н. Интегрированное (инклюзивное) образование: генезис и проблемы внедрения / Н. Назарова // Социальная педагогика. - 2010. - №1.

6. Наумов А.А. Интегрированное и инклюзивное обучение в образовательном учреждении. Инновационный опыт/ А.А. Наумоы, В.Р. Соколова, А.Н. Седегова - Волгоград: Учитель, 2012.

7. Яковлева И.М. Подготовка педагогов к реализации инклюзивного образования // Инклюзивное образование: методология, практика, технологии.

\section{Киселева Е.В. \\ Формирование основных движений младших дошкольников через организацию подвижных игр}

Самарский сочиильно-педагогический колледж (Россия, Самара)

doi: $10.18411 / s r-10-08-2017-03$

idsp: 000001:sr-10-08-2017-03

\section{Аннотация}

В данной статье рассматривается проблема формирования основных движений младших дошкольников. Соблюдение методики руководства педагогом при регулярном проведении подвижных игр, способствует лучшему выполнению основных движений младших дошкольников.

Ключевые слова: дошкольники, основные движения, младший дошкольный возраст, методика проведения подвижных игр.

По исследованиям НИИ гигиены и профилактики заболеваний, состояния здоровья и физического развития детей дошкольного возраста известно, что функциональные возможности детей младшего дошкольного возраста не реализуются на должном уровне в процессе разных видов занятий по физической культуре. Кроме того, двигательная активность дошкольников за время пребывания их в детском саду составляет 50\% периода бодрствования, что не позволяет полностью обеспечить биологической потребностью ребенка в движении. Это заставляет педагогов искать пути оптимизации движений за счёт проведения подвижных игр.

Следуя актуальности проблемы, было проведено исследование: «Формирование основных движений младших дошкольников через организацию подвижных игр».

Цель-изучить влияние подвижных игр на совершенствование основных движений детей младшего дошкольного возраста.

Задачи исследования:

1. Изучить техническую характеристику и методику формирования упражнений в лазании у дошкольников.

2. Раскрыть методику организации и проведения подвижных игр с дошкольниками.

3. Исследовать влияние подвижных игр на совершенствование основных движений младших дошкольников. 
Была выдвинута гипотеза, что проведение подвижных игр будет способствовать совершенствованию основных движений младших дошкольников, если:

- движения будут предварительно разучены на физкультурных занятиях;

- методика проведения подвижных игр будет учитывать психические и физиологические особенности детей 3-4 лет.

Изучив рекомендации Алямовской, Глазыриной Л.Д, Степаненковой Э.Я., Лайзане С.Я., Овсянкина В.А., Кенеман А.В., Хухлаевой Д.В. и др., мы приступили к проведению исследовательской деятельности.

Исследование проходило на базе второй младшей группы МБДОУ «Детский сад № 455», Кировского района г. о. Самара. Были выбраны 2 группы детей 3-4 лет экспериментальная и контрольная (по 10человек)

Сроки: с сентября 2016г. по апрель 2017 года.

Определена цель - сравнить уровень выполнения подлезания детьми четвёртого года жизни на физкультурном занятии и в подвижной игре.

Задачи:

1. Подобрать диагностические методики обследования основных движений детей младшего дошкольного возраста и провести диагностику

2. Освоить методику проведения подвижных игр с детьми младшего дошкольного возраста, ориентированную на этапы развития подвижной игры и особенности реакции детей 3-4 лет.

3. Организовать проведение подвижных игр с постепенным усложнением выполнения основного движения

4. Проанализировать результаты педагогической деятельности эксперимента.

На основе целевых ориентиров предлагаемых программой «От рождения до школы» под ред. Вераксы Н.Е (2015г) и методики обучения выполнения упражнений в подлезании (Хухлаева Д.В., Степаненкова Э.Я.) был проведён констатирующий эксперимент. Мы начали с диагностики упражнения в подлезании под шнур, подвешенный на высоте 50см. (способом «головой вперед»), выполняемого детьми на физкультурном занятии.

Цель: выявление умения детей подлезать под шнур, подвешенный на высоте 50 см., способом «головой вперед».

Выполнение: при подлезании способом «головой вперед» ребенок, наклонившись, сначала проносит голову, затем прогибаясь в спине, передвигает одну ногу, потом другую.

Для реализации задач эксперимента мы провели подвижную игру «Наседка и цыплята».В игре детям следовало выполнять подлезание под высоту 50 см. и тем же способом. Дети экспериментальной и контрольной групп продемонстрировали лучший уровень выполнение подлезания в подвижной игре. На этом основании был разработан перспективный план формирующего эксперимента для детей экспериментальной группы, основанный на проведении подвижных игр с усложнением выполнения подлезания.

Перспективный план совершенствования упражнений в подлезаниис февраля по март 2017г. при проведении подвижных игр с детьми экспериментальной группыМБДОУ «Детский сад № 455г.о.Самара

\begin{tabular}{|c|c|c|}
\hline $\begin{array}{c}\text { Месяц, № } \\
\text { недели }\end{array}$ & Игра & Задачи \\
\hline $\begin{array}{c}\text { Февраль } \\
1 \text { неделя }\end{array}$ & $\begin{array}{c}\text { «Наседка и } \\
\text { цыплята» }\end{array}$ & $\begin{array}{c}\text { Задачи: Упражнять детей в подлезании под высоту 50 см., в беге } \\
\text { врассыпную, стайкой и по прямой; развивать реакцию на словесный } \\
\text { сигнал. }\end{array}$ \\
\hline $\begin{array}{c}\text { Февраль } \\
2 \text { неделя }\end{array}$ & «Кролики» & $\begin{array}{c}\text { Задачи: Упражнять детей в подлезании под высоту 50 см., в беге } \\
\text { врассыпную, стайкой и по прямой. Развивать умение выполнять } \\
\text { движения по сигналу. }\end{array}$ \\
\hline
\end{tabular}




\begin{tabular}{|c|c|c|}
\hline $\begin{array}{l}\text { Февраль } \\
3 \text { неделя }\end{array}$ & $\begin{array}{c}\text { «Мыши в } \\
\text { кладовой» }\end{array}$ & $\begin{array}{c}\text { Задачи: : Упражнять детей в подлезании под высоту } 50 \text { см., в беге } \\
\text { врассыпную, стайкой и по прямой. Развивать у детей умение выполнять } \\
\text { движения по сигналу. }\end{array}$ \\
\hline $\begin{array}{c}\text { Март } \\
1 \text { неделя }\end{array}$ & $\begin{array}{c}\text { «Наседка и } \\
\text { цыплята» }\end{array}$ & $\begin{array}{c}\text { Задачи: Упражнять детей в подлезании под высоту } 48 \text { см., в беге } \\
\text { врассыпную, стайкой и по прямой; развивать реакцию на словесный } \\
\text { сигнал. }\end{array}$ \\
\hline $\begin{array}{c}\text { Март } \\
2 \text { неделя }\end{array}$ & «Кролики» & $\begin{array}{l}\text { Задачи: Упражнять детей в подлезании под высоту } 48 \text { см., в беге } \\
\text { врассыпную, стайкой и по прямой. Развивать умение выполнять } \\
\text { движения по сигналу. }\end{array}$ \\
\hline $\begin{array}{c}\text { Март } \\
3 \text { неделя }\end{array}$ & $\begin{array}{c}\text { «Мыши в } \\
\text { кладовой» }\end{array}$ & $\begin{array}{c}\text { Задачи: : Упражнять детей в подлезании под высоту } 47 \text { см., в беге } \\
\text { врассыпную, стайкой и по прямой. Развивать у детей умение выполнять } \\
\text { движения по сигналу. }\end{array}$ \\
\hline $\begin{array}{c}\text { Март } \\
4 \text { неделя }\end{array}$ & $\begin{array}{l}\text { «Наседка и } \\
\text { цыплята» } \\
\text { «Кролики» }\end{array}$ & $\begin{array}{c}\text { Задачи: Упражнять детей в подлезании под высоту } 47 \text { см., в беге } \\
\text { врассыпную, стайкой и по прямой; развивать реакцию на словесный } \\
\text { сигнал. } \\
\text { Задачи: Упражнять детей в подлезании под высоту } 46 \text { см., в беге } \\
\text { врассыпную, стайкой и по прямой. Развивать умение выполнять } \\
\text { движения по сигналу. }\end{array}$ \\
\hline $\begin{array}{c}\text { Апрель } \\
1 \text { неделя }\end{array}$ & $\begin{array}{l}\text { «Мыши в } \\
\text { кладовой» } \\
\text { «Кролики» }\end{array}$ & $\begin{array}{c}\text { Задачи: : Упражнять детей в подлезании под высоту } 46 \text { см., в беге } \\
\text { врассыпную, стайкой и по прямой. Развивать у детей умение выполнять } \\
\text { движения по сигналу. } \\
\text { Задачи: Упражнять детей в подлезании под высоту } 45 \text { см., в беге } \\
\text { врассыпную, стайкой и по прямой. Развивать умение выполнять } \\
\text { движения по сигналу. }\end{array}$ \\
\hline $\begin{array}{c}\text { Апрель } \\
2 \text { неделя }\end{array}$ & $\begin{array}{c}\text { «Наседка и } \\
\text { цыплята» }\end{array}$ & $\begin{array}{c}\text { Задачи: Упражнять детей в подлезании под высоту } 45 \text { см., в беге } \\
\text { врассыпную, стайкой и по прямой; развивать реакцию на словесный } \\
\text { сигнал. } \\
\text { Задачи: : Упражнять детей в подлезании под высоту } 45 \text { см., в беге } \\
\text { врассыпную, стайкой и по прямой. Развивать у детей умение выполнять } \\
\text { движения по сигналу. }\end{array}$ \\
\hline
\end{tabular}

При проведении новых или малознакомых подвижных игр с детьми экспериментальной группы, была применена иная методика подачи сигнала на окончание игровых действий, т.к. в 3-4 года реакция внимания затруднена у малышей. Сигнал подавался в три этапа, например:

первый - уточнение изменения действий (большая птица);

второй - как необходимо отреагировать (убегайте);

третий - непосредственно звуковой сигнал (Кар-кар).

Кроме того игру организовывали таким образом, чтобы каждый малыш, независимо от физических возможностей, оказался в позиции выигрыша. Если на окончание игры ребёнок не реагировал (не прячется в свой домик), воспитатель в одну руку брал игрушку (Ворону), другой - руку малыша и, сохраняя дистанцию между игрушкой и ребёнком, заводил малыша в игровой домик. Сразу озвучивая похвалу: «Молодцы дети! Все убежали от Большой птицы!» Всё это способствовало увеличению интереса к выполнению основных движений в подвижных играх.

В контрольном эксперименте мы вновь провели обследование детей обеих групп, применив методику констатирующего эксперимента.

Анализ данныхполученных в контрольном эксперименте показывает, что в процессе игры дети экспериментальной группы стали заметно увереннее выполнять упражнение, движения выполнялись последовательно, повысилась активность и старательность выполнения основных движений.

Результаты приведены в сравнительной диаграмме контрольного эксперимента по результатам обследования подлезаниядетей в подвижной игре (рис.1).Показатели подлезания у детей экспериментальной группы оказались чуть лучше, чем у детей контрольной группы, но, всё же не имели большой разницы. Однако, дети экспериментальной группы проявляли не только желание участвовать в подвижных играх, но и просили поиграть в игры, которые были включены в их двигательную 
деятельность в формирующем эксперименте. Мы считаем, что эти игры были понятны по выполнению движений и образному содержанию, вызывали положительные эмоции, поэтому и вызывали больший интерес.

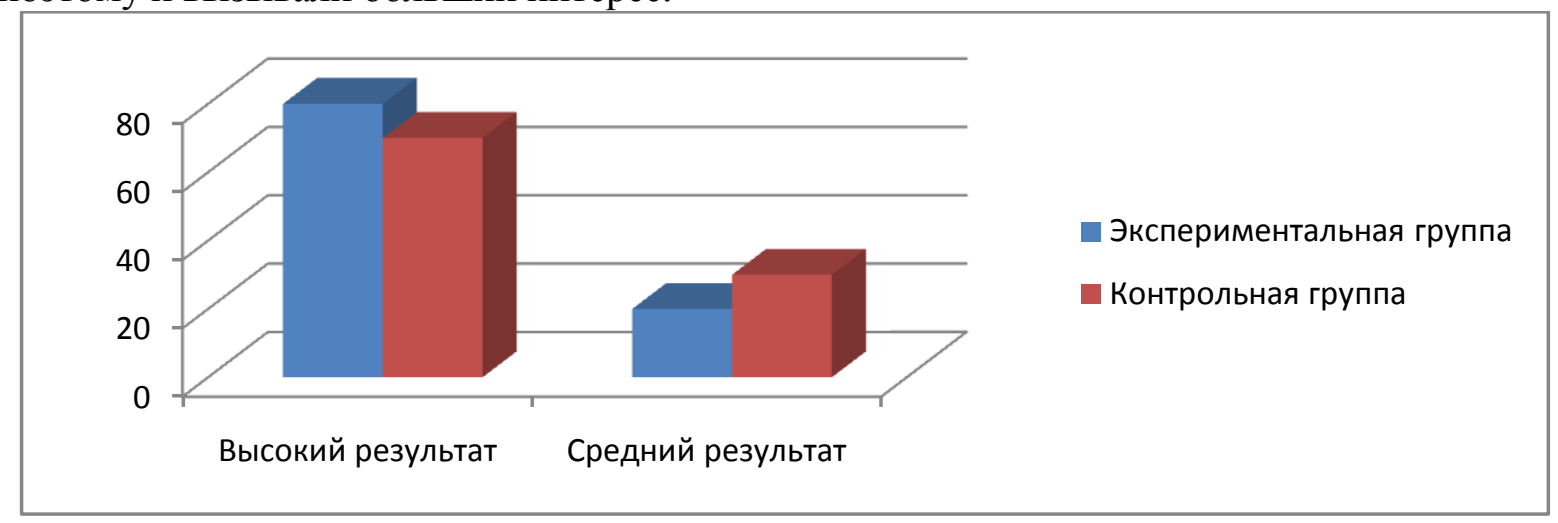

Рис.1 - Сравнительная диаграмма результатов обследования подлезания в подвижной игре детей экспериментальной и контрольной групп в контрольном эксперименте.

Из полученных данных мы делаем вывод, наши результаты подтвердили мнение физиологов и педагогов, в том числе Степаненковой Э.Я., что в младшем дошкольном возрасте активно участвуют в движении только крупные группы мышц, поэтому у малышей не будет проявляться существенной разницы качества выполнения основных движений.

Неоспоримо, что выполнение детьми этих движений в подвижной игре идёт с большим интересом и желанием: высокий уровень мотивации - сама подвижная игра с её атрибутами, точное пояснение педагога во время выполнения основного движения детьми, учёт возрастных особенностей при подаче сигнала на окончание игровых действий обеспечивает более качественное выполнения основного движения.

Важно, как можно чаще, упражнять малышей в выполнении основных движений и делать это нужно применяя подвижные игры, доступные детям.

Таким образом, проведение подвижных игр, является эффективным средством совершенствования основных движений детей младшего дошкольного возраста.

Наша гипотеза нашла свое подтверждение: действительно, проведение подвижных игр, способствовало лучшему выполнению основных движений младших дошкольников, Т.К.:

- движения были предварительно разучены на физкультурных занятиях;

- методика проведения подвижных игр учитывала психические и физиологические особенности детей 3-4 лет, что заключалось в пояснении этапов выполнения движений и подаче сигнала на окончание игровых действия в три этапа.

Рекомендации педагогам ДОУ по применению методики проведения подвижные игр с детьми младшего дошкольного возраста, способствующей развитию основных движений.

1. При выборе подвижных игр ориентироваться на образовательную программу «От рождения до школы», под редакцией Н.Е. Вераксы, Т.С. Комаровой, М.А.Васильевой.

2. Во время проведения игры пояснять для детей все фазы выполнения основного движения.

3. Для методически правильного проведения подвижных игр, учитывать психологические особенности младших дошкольников:

- проводить игровые действия,без предварительного объяснения содержания игры; 
- сигнал на окончание игровых действия организовывать в три этапа.

4. По мере накопления детьми двигательного опыта усложнять само основное движение в соответствии с возрастными возможностями детей.

$* * *$

1. Железняк, Ю.Д. Основы научно-методической деятельности в физической культуре и спорте: учеб.пособие для студ. Высш. Учеб. Заведений / Ю.Д. Железняк, П.К. Петров. - 3-е изд., испр. - М., 2007. $-73 \mathrm{c}$.

2. Программа «От рождения до школы», под ред.Н.Е. Вераксы, Т.С. Комаровой, М.А.Васильевой - М.: Мозаика-Синтез, 2015

3. Шишкина, В. А., Дедулевич М. Н. Двигательное развитие дошкольника. Редактор: Шумак С. Е. Издательство: Белый ветер, 2014 г.- 136 с. 


\title{
РАЗДЕЛ ІІ. ПСИОЛОГИЯ
}

\author{
Богослова Е.Г. ${ }^{1}$, Сюкиев Д.Н. ${ }^{2}$ \\ Сущностно-содержательная характеристика Я концепции личности \\ ${ }^{1}$ Крымский инженерно-педагогический университет \\ (Россия, Симферополь) \\ ${ }^{2}$ Калмыцикий государственный университет \\ (Россия, Элиста)
}

doi: 10.18411/sr-10-08-2017-04

idsp: 000001:sr-10-08-2017-04

\section{Аннотация}

В статье представлено сформулированное на основе анализа и обобщения отечественной и зарубежной психологической литературы авторское понимание сущности и содержания Я-концепции личности, ее роли в жизнедеятельности человека, факторов ее развития.

Ключевые слова: Я-концепции, сущность, содержание, функции, факторы развития.

\section{Abstract}

In the article worded on the basis of the analysis and synthesis of domestic and foreign psychological literature the author's understanding of the essence and contents of the self concept of identity, its role in human life, factors of its development.

Keywords: selfconcept, the essence, contents, functions, factors of development.

Современным обществом востребована творчески мыслящая личность, способная к принятию нестандартных решений, самостоятельному пополнению и приобретению знаний. Во второй статье Закона Российской Федерации «Об образовании» подчеркивается, что образование должно быть ориентировано на обеспечение самоопределения личности, создание условий для ее самореализации.В образовательной практике все чаще используются термины, начинающиеся с приставки «само», «сам», которые в интегративном виде характеризуют человека как субъекта собственного развития. На первый план выдвигается задача воспитания мотивированной, инициативной, самостоятельной личности, ориентированной на построение и реализацию продуктивных сценариев своего жизненного и профессионального пути. Основным приоритетом педагогической деятельности становится целенаправленное и систематическое руководство становлением творческой личности, способной к саморазвитию и самореализации $[5,7,8,10,13$ др.].

Между тем, достижение этой стратегической цели затруднено в связи с наличием в научно-методической литературе различных подходов к пониманию Я-концепция личности. Необходимость разрешения этого противоречия обусловливает актуальность задачи нашего исследования, суть которой заключается в уточнении на основе анализа и обобщения зарубежной и отечественной психологической литературы сущности и содержания понятия «Я-концепции» личности.

Результаты исследования. Несмотря на отсутствие в отечественной и зарубежной психологической литературе единой трактовки сущности понятия «Яконцепция〉 большинство ученых сходятся в его понимании как совокупности установок человека, направленных на самого себя.При этом зарубежные ученые [1, 3, 8, 14 и др.] рассматривают Я-концепцию преимущественно как психический образ, в то время как 
наши психологи [9, 11, 13 и др.] видят в самосознании как психический процесс (осознавание и оценивание своего «Я» в процессе социальной активности), так и результат этого процесса (осознание и оценка).В психологическом содержании этих установок выделяются три взаимосвязанных компонента $[1,4,13,15$ и др.]: образ Я (представление человека о самом себе); самооценка (аффективная оценка этого представления); 3) потенциальная поведенческая реакция.

Существенное значение для решения проблемы нашего исследования представляет вопрос о содержаниипонятия Я-концепция. В реальной жизни установки человека по отношению к себе многоплановы. Они могут относиться к разным сферам проявления человека.

В психологической литературе выделяются различные формы представлений о себе, дифференцированные:по сфере проявлений человека («социальное Я», «духовное Я», «физическое Я», «интимное Я», «публичное Я», «моральное Я», «семейное Я» и т. д.); как реальность и идеал («реальное Я», «идеальное Я», «зеркальное «Я») $[1,3,6]$, на временном континиуме («Я в прошлом», «Я в настоящем», «Я в будущем») [12].

Введение этих понятий значимо, поскольку для педагогической практики необходимо знать, в какой именно сфере деятельности субъект переживает себя состоятельным или несостоятельным, на чем содержательно базирует свое самоуважение, стремится ли к достижению своего идеала, переживает ли разорванность своего «интимного «Я» и публичной самопрезентации. Все эти специфически-контекстные Яконцепции могут значительно различаться, вступать в противоречие и даже в конфликт.

Я-концепция существенно влияетна все жизненные проявления человека - с самого детства до глубокой старости. В психологической литературе большинством авторов [1,8,12 и др.] выделяются три основные функции Я-концепции в процессах саморегуляции поведения и самоорганизации личности.

Во-первых, Я-концепция рассматривается как средство обеспечения внутренней согласованности, как средство разрешения противоречий между реальным Я и идеальным Я, реальным Я и зеркальным Я $[8,16$ и др.].Достижение человеком внутренней гармонии может быть достигнуто через действия в двух противоположных направлениях - через применение механизмов психологической защиты и через активное преобразование самого себя, обеспечивающего приближение реального Я к идеальному или зеркальному Я [1,9 и др.].

В рамках исследуемой нами проблемы важным является утверждение И.И.Чесноковой о том, что самосознание является одним из необходимых внутренних условий непрерывного развития личности, устанавливающим равновесие между внешними влияниями, внутренним состоянием личности и формами ее поведения [15]. С нею солидарен В.В. Столин [12] который подчеркивает, что структуры самосознания могут мотивировать личность, участвовать в целеобразовании, воспрещать те или иные поступки и действия, детерминировать отношение к окружающим, влиять на развитие тех или иных черт и развитие личности в целом, служить формой самоконтроля и быть основанием приобщения субъекта к другим людям.

Вторая функция Я-концепции в поведении заключается в индивидуальной интерпретации опыта личности [8]. У человека существует устойчивая тенденция строить на основе собственных представлений о себе не только свое поведение, но и интерпретацию своего опыта и действий других людей.

Третьей функцией Я-концепции выступает определение совокупности ожиданий человека, то есть его представлений о том, что должно произойти, что во многом определяет характер действий человека [8].

Для решения педагогической проблемы формирования Я-концепции необходимо учитывать факторы, влияющие на ее развитие. Анализ научно-методической литературы показывает, что большинство зарубежных исследователей считают, что Я-концепция возникает и развивается в процессе социального взаимодействия. [8, 3 и др.].Человек 
является социальным существом, и поэтому не может избежать принятия многих социальных и культурных ролей, нормативов и оценок, определяемых условиями жизни в обществе. Он становится объектом и собственных суждений, и оценок других людей, с которыми взаимодействует и, если он стремится получить одобрение окружения, он должен соответствовать общепринятым стандартам.

На социальную обусловленность самосознания обращали внимание и отечественные ученые. В частности, Л.С. Выготский определял самосознание как социальное сознание, перенесенное внутрь [2], С.Л. Рубинштейн подчеркивал, что «Я» не существует вне отношений к «Ты» [9].Ряд авторов считают, что развитие Я-концепции зависит как от избирательного восприятия мнения других, так и во многом определяется активностью самой личности, направленной на становление Эго-идентичности [16], на познавательное, эмоциональное и волевое осмысление собственного «Я» [9].

Заключение. Таким образом, нами в ходе анализа и обобщения литературных данных были уточнены сущность и содержание понятия «Я-концепция», ее роль в жизнедеятельности человека и факторы ее развития.Мы понимаем под Я-концепцией комплекс установок человека, которые характеризуются совокупностью представлений о себе, отношений к себе и готовностью к активности в отношении себя.Я-концепция возникает и формируется у человека в процессе социального взаимодействия как неизбежный и всегда уникальный результат психического развития, приобретаемый на основе жизненного опыта, как относительно устойчивое и в то же время подверженное внутренним изменениям и колебаниям психическое приобретение. Оно оказывает существенное влияние на интерпретацию жизненного опыта, на жизненные цели, которые человек ставит перед собой, на соответствующую систему ожиданий, прогнозов относительно будущего, оценку их достижения и тем самым на жизнедеятельность человека в целом - с самого детства до глубокой старости. Если первоначально Яконцепции зависит от внешних влияний, но в дальнейшем она играет самостоятельную роль в жизни каждого человека.

Окружающий мир, представления о других людях воспринимаются человеком сквозь призму Я-копцепции, формирующейся в процессе социализации, воспитания. В отличие от ситуативных Я-образов (каким человек видит и ощущает себя в каждый данный момент) Я-концепция создает у человека ощущение своей постоянной определенности, самотождественности.

$$
* * *
$$

1. Бернс,Р. Развитие Я-концепции и воспитание / Р. Бернс. - М.: Прогресс, 1986. -422 c.

2. Выготский,Л.С. Педагогическаяпсихология / Л.С. Выготский. - М.: Педагогика, 1991. - 387 с.

3. Джеймс,У. Психология / У. Джеймс; [под ред. Л.А. Петровской]. - М.: Педагогика, 1991. - 368 с.

4. Кон, И.С. В поисках себя: Личность и ее самосознание / И.С. Кон. - М.: Политиздат, 1984. -335 с.

5. Маралов, В.Г. Основы самопознания и саморазвития: учебное пособие / В.Г. Маралов. - М.: Академия, 2004. $-256 \mathrm{c}$.

6. Орлов, Ю.М. Самопознаниеисамовоспитаниехарактера. Беседы психолога со старшеклассниками: книга для учащихся / Ю.М. Орлов. - М.: Просвещение, 1987. -224 с.

7. Райе, Ф. Психология подросткового и юношеского возраста / Ф. Райе. - СПб.: Питер, 2000. - 624 с.

8. Роджерс, К. Взгляд на психологию. Становление человека / К. Роджерс. - М.: Прогресс; Универс, 1994. $-480 \mathrm{c}$.

9. Рубинштейн, С.Л. Основы общей психологии / С.Л. Рубинштейн. - СПб.: Питер, 2000. - 712 c. - (Серия «Мастера психологии»).

10. Ситаров, В.А. Педагогика и психология ненасилия в образовательном процессе [Текст]: учеб. пособие / В.А. Ситаров, В.Г. Маралов; [под ред. В.А. Сластенина]. - М.: Академия, 2000. - 216 с.

11. Спиркин, А.Г. Сознание и самосознание / А.Г. Спиркин. - М.: Политиздат, 1972. - 302 с.

12. Столин, В.В. Самосознание личности / В.В. Столин. - М.: Изд-во МГУ, 1983. -284 с.

13. Фельдштейн, Д.И. Психология развивающейся личности / Д.И. Фельдштейн. - М.; Воронеж, 1996. $512 \mathrm{c}$.

14. Фромм, Э. Психоанализ и этика / Э. Фромм. - М.: Республика, 1993. -415 с.

15. Чеснокова, И.И. Проблемы самосознания в психологии / И.И. Чеснокова. - М.: Наука, 1989. -144 с.

16. Эриксон, Э. Идентичность: юность и кризис / Э. Эриксон. - М.: Прогресс, 1996. - 344 с. 


\section{РАЗДЕЛ ІІІ. ЭКОНОМИКА}

\section{Ермакова Г.А. \\ Формирование понятия «интеллектуальный капитал» организации представителями различных экономических школ}

Северо-Кавказский федеральный университет (Россия, Ставрополь)

doi: 10.18411/sr-10-08-2017-05

idsp: 000001:sr-10-08-2017-05

\section{Аннотация}

В статье изучены трактовки экономической категории «капитал», на основании чего установлено, что представители разных экономических школ признавали ценность интеллектуального капитала, отмечая его участие в создании прибавочной стоимости. Вместе с тем большинство зарубежных и российских экономистов в ретроспективе и современных условиях признают человеческий капитал фактором производства, формируя в итоге концепцию человеческого капитала.

Ключевые слова: капитал, интеллектуальный капитал, прибавочная стоимость, добавленная экономическая стоимость, концепция человеческого капитала.

В экономической теории и бизнесе, пожалуй, нет понятия, которое бы использовалось столь часто и одновременно неоднозначно. Категория «капитал» - одна из наиболее фундаментальных и основополагающих.

Капитал (лат. capitalis - главный): совокупность производственных отношений капиталистического способа производства, при которых объекты интеллектуальной собственности, средства труда, определённые материальные блага, деньги, и разные виды ценных бумаг выступают орудием эксплуатации, присваивания части чужого неоплаченного труда. [9].

Представители маржиналистского направления: К. Менгер, У. С. Джевонс, Л. Вальрас не признавали влияния финансового капитала на воспроизводственный процесс, учитывая наряду с зданиями, орудиями труда, материалами, транспортными коммуникациями в качестве необходимых средств производства - труд. При этом капитал характеризовали фактором производства из совокупности полезных благ, удовлетворяющих все обычные желания и потребности рабочего, предоставляя ему возможность заняться видами работ, в результате которых получается доход [5].

К. Маркс раскрывал экономическую сущность капитала на базе учения о прибавочной стоимости, характеризуя категорию в социальном аспекте. По его мнению, капитал - это самовозрастающая стоимость, рождающая так называемую прибавочную стоимость. Деньги становятся капиталом, когда на них приобретаются средства производства и рабочая сила, считая создателем прироста прибавочной стоимости труд наёмных рабочих. Тем самым К. Маркс обозначает участие интеллектуального капитала в создании прибавочной стоимости [8, с. 275].

По мнению А Смита, капитал - произведенные средства производства, приобретенные способности рабочих к труду, безусловно, «произведены» при использовании вещественных ресурсов. Разделяя капитал на оборотный и основной, А. Смит признает, что термин «капитал» используется для характеристики активов организации, непосредственно включая в составе основного как орудия труда и постройки, так и человеческий капитал - капитализированную ценность «приобретенных и полезных способностей всех жителей и членов общества». Т. е. по его мнению, капитал, 
с одной стороны, стоимость, обеспечивающая прирост благодаря эксплуатации наёмного труда, а с другой стороны - запас средств производства [1, с. 210]. В результате А. Смит также как и К. Маркс признает ценность интеллектуального капитала.

Американский неоклассик-экономист Б. И. Фишер допускает включение в капитал любого блага, приносящего постоянный доход своему владельцу со стоимостной оценкой [5].

Представитель австрийской школы Е. фон Бем-Баверк рассматривал капитал промежуточным продуктом, созданным природой и трудом, акцентируя внимание при этом на понятии капитала как «совокупное орудий производства» [5].

П. Самуэльсон выделяя в определении капитала ключевое свойство - приносить доход, рассматривает его богатством, выступающим результатом прошлого труда в частной собственности [5].

Идеолог либерализма и представитель классической школы Дж. С. Милль в одной из теорем капитала отмечает, что капитал - результат сбережения, которое должно возрасти, если стоит вопрос о найме новых работников и увеличении производства, а сбережения необходимо использовать производительно - только в качестве капитала [1, с. 198].

Итак, капитал как экономическая категория отражает, прежде всего, определённую сумму материальных, денежных и интеллектуальных средств, позволяющих своему владельцу вести бизнес. Соответственно в экономической науке концепция человеческого капитала, в современной интерпретации - интеллектуального функционирует наряду с монетарной и денежной концепциями.

Ее последователи М. Беккер, Б. Вейсброд, П. Гутман, А. Хансен, Т. Шульц, Л. Туроу и др. рассматривая человеческий капитал фактором производства, относя к нему физические, интеллектуальные, психические силы человека - врождённые и полученные в процессе обучения, труда, общения с иными людьми [5]. Такая теория переносит акцент с использования трудовых ресурсов на проблемы формирования качественно новой рабочей силы в условиях научно-технической революции. T. е. уже теория «человеческого капитала» определяет трудовые привычки, способности работников составляющей основного капитала, подчеркивая в итоге значимость интеллектуального капитала. Труд, в т. ч интеллектуальный - 2-я движущая сила производства, объединяющая организации для получения некоторого продукта, приобретается по необходимости. Следует подчеркнуть, что активация человеческого капитала, способности одних людей разрабатывать новые идеи, а других - их объективно оценивать, принимая решения по их вводу, опыт и возможности профессионально решать поставленные задачи - основное звено при создании новых внутренних / внешних условий, в которых работает организация, т. е. основной фактор, движущая сила развития инноваций. В современный период стоимость человеческого потенциала Китая $\approx 200-$ 300 млрд юаней (33 - 48 трлн долл.).

Современный экономист В. В. Бочаров, характеризуя капитал организации как стоимость средств также наряду с его денежной, материальной формами выделяют нематериальную, вложенные в активы организации с обозначением его основного признака - богатство для его собственного роста [3].

А. Б. Борисов, Б. А. Райзберг, Л. Ш. Лозовский, Е. Б. Стародубцева в широком смысле относят к капиталу все, способное приносить доход [2].

Авторский коллектив под редакцией А. В. Гуковой обозначает в создании инвестиционного капитала прошлый труд [4].

Итак, справедливо отметить, что капитал - сложная экономическая категория, находящаяся в постоянном движении, главное свойство которого - способность приносить доход - все приносящее / способное приносить доход [6]. 
По результатам проведенных исследований:

- выявлены, что представители разных экономических школ признавали ценность интеллектуального капитала, отмечая его участие в создании прибавочной стоимости (К. Маркс, А. Смит и др.);

- установлено, что большинство зарубежных (Е. фон Беем-Баверк, П. Самуэльсон, М. Беккер, Б. Вейсброд, П. Гутман, А. Хансен, Т. Шульц, Л. Туроу и др.) и российских (А. В. Гукова и др.) экономистов в ретроспективе и современных условиях признают человеческий капитал фактором производства, доказывая тем самым равноправное существование концепции интеллектуального капитала.

$$
* * *
$$

1. Блауг, М. Экономическая мысль в ретроспективе; пер. с англ. - 4-е изд. - М.: «Дело Лтд», 1994. - с. 210.

2. Борисов, А. Б. Большой экономический словарь / А. Б. Борисов. - М.: Книжный мир, 2009. - 864 с.

3. Бочаров, В. В. Современный финансовый менеджмент / В. В. Бочаров. - СПб. : Питер, 2006. - 464 с.

4. Гукова, А. В. Инвестиционный капитал предприятия / А. В. Гукова, А. Ю. Егоров ; под общ. ред. А. Ю. Егорова. - М. : КНОРУС, 2006. - 276 c.

5. Майбурд, Е. М. Введение в историю экономической мысли. От пророков до профессоров / Е. М. Майбурд. - М.: Дело, Вита-Пресс, 2000. - 560 с.

6. Мануйленко, В. В. Совершенствование методики оценки достаточности собственных средств (капитала) коммерческого банка: монография / В. В. Мануйленко, А. В. Малеева. - Ставрополь : ГОУ ВПО «СевКавГТУ», 2006. -209 с.

7. Маркс, К. Капитал. Т.1 / К. Маркс. - М. : Издательство политической литературы, 1969.

8. Экономика: учебник / под ред. д-ра экон. наук проф. Булатова А. С. - 4-е изд., перераб. и доп. - М.: Экономисть, 2008. - $831 \mathrm{c}$.

9. Экономическая энциклопедия / под ред. С. В. Мочерный. - К. $-2000 .-719$ с.

\section{Жамлиханова Л.3. Деятельность Центрального банка Российской Федерации \\ Российский государственный университет им.А.Н. Косыгина (Россия, Москва)}

doi: $10.18411 / \mathrm{sr}-10-08-2017-06$

idsp: 000001:sr-10-08-2017-06

Центральный банк благодаря своему функциональному предназначению занимает особую нишу в банковской системе любого государства. В каждой стране Центральный банк должен иметь наименование, отличное от наименования аналогичного банка на территории другой страны: в Китае - Народный банк Китая, в Германии - Немецкий федеральный банк, в Швеции - Риксбанк (отшвед. «riks»- государственный), в Австралии - Резервный банк Австралии и т.д.[1, с. 224]

ЦБ РФ в силу своей двойственной правовой природы, как государственный орган специальной компетенции, обладает широкими властными полномочиями, предоставляющими право осуществления всестороннего управления банковской системой и, одновременно с этим, являясь юридическим лицом, он праве вступать в гражданско-правовые отношения с российскими и иностранными кредитными организациями.

ЦБ РФ состоит из четырехступенчатой системы управления:

1. первый уровень - Национальный финансовый совет, состоящий из 12 членов, основными функциями которого были:

- проверка годового отчета ЦБ РФ и заслушивание доклада главного аудитора ЦБ РФ;

- мониторинг путей дальнейшего развития банковской системы РФ; 
- практическая реализация приоритетных направлений развития государственной денежно-кредитной политики и др.

2. второй уровень - Совет директоров, который не реже одного раза в квартал выносит на обсуждение вопросы функционирования банковской системы. Среди основных функций Совета директоров можно выделить следующие:

- предоставление на Национальный финансовый совет предстоящих расходов ЦБ РФ на будущий год с расчетами и аргументацией;

- определение правил и регламента проведения операций внутри банковской системы утверждение отчета о деятельности ЦБ РФ за финансовый год;

- вынесениепроекта приоритетных направлений развития денежнокредитной политикигосударствана Национальный финансовый совет;

- утверждение правил ведения бухгалтерского учета и сдачи отчетности для кредитных организаций и др.

3. третий уровень - территориальные учреждения-филиалы ЦБ РФ, в обязанности которых входит:

- осуществление проверок выполнения кредитными организациями обязательных требований, и в ситуации, когда нарушения имели место, наложение штрафных санкций;

- анализ состояния и перспектив развития экономической ситуации в целом и отдельных региональных финансовых рынков.

4. четвертый уровень - расчетно-кассовые центры, в обязанности которых входит:

- проверкаправильности расчетов между кредитными организациями и их филиалами и кассовое их обслуживание;

- защита конфиденциальной и иной информации, представляющей ценность, от несанкционированного доступа;

- прием клиентов, в регионах проживания которых отсутствуют кредитные организации.

ЦБ РФ выполняет функции, которые носят взаимосвязанный характер:

- регулирование экономической ситуации в РФ;

- $\quad$ выполнение функций резервной системы;

- $\quad$ проведение государственной эмиссионной и валютной политики;

- публикация официальных курсов иностранных валют относительно рубля, статистических данных и других материалов;

- обеспечение устойчивости рубля;

- $\quad$ осуществление контроля за деятельностью кредитных организаций;

- $\quad$ установка правил ведения бухгалтерского учета и отчетности;

- $\quad$ проведение регистрации кредитной организации;

- $\quad$ надзор за порядком совершения банковских операций;

- применение крайней меры воздействия в отношении кредитных организаций - отзыв лицензии;

- $\quad$ анализ с последующим прогнозированием состояния экономической ситуации по стране в целом и по отдельным ее регионам и др.[2, с. 400]

В программе ЦБ РФ на предстоящий трехлетний период значится завершение перехода к инфляционному таргетированию (от англ. «inflationtargeting»- комплекс мероприятий по контролированию уровня инфляции), сохраняя при этом 
преемственность принципов денежно-кредитной политики страны, осуществляемых сегодня.

В соответствии с данным режимом основной задачей денежно-кредитной политики ЦБ РФ является снижение темпов прироста потребительских цен в 2013 году до 7\%, в 2014 и 2015 годах - до 5\%, контролирование уровня инфляции осуществляется путем поддержания низких темпов роста цен. [3]

В сфере денежно-кредитной политики ЦБ РФ ежемесячно будет принимать решения, руководствуясь следующими данными: оценка функционирования экономики, инфляционные ожидания, характерные черты экономики страны, отслеживание негативных либо положительных перемен вследствие влияния на нее денежно-кредитной политики. На сегодняшний день достигнут максимальный контроль над процентными ставками благодаря реализации ЦБ РФ политики, сосредоточенной на усовершенствовании системы инструментов, оказывающих влияние на денежный рынок.

На среднесрочную перспективу основными задачами ЦБ РФ будут являться:

- создание устойчивой, способной приспосабливаться к любым изменениям внешней среды банковской инфраструктуры;

- $\quad$ мониторинг потенциальных рисков в банковском секторе и сведение их к минимуму;

- проведение надзора за кредитными организациями и обеспечение прозрачности их деятельности в зависимости от следующих факторов: их положение в банковской сфере, степень влияния, соблюдение законов и правил, установленных ЦБ РФ, или же уклонение от них и др.

Как показывает зарубежная практика, при реализации вышеназванных задач наиболее эффективным инструментом может служить риск-фокусированный надзор, в рамках которого уделяется повышенное внимание своевременной идентификации и прогнозированию риска и оценке общей устойчивости финансовой системы.[4, с. 13-23]

Для коммерческих банков ЦБ РФ является кредитором последней инстанции - он оказывает кредитную поддержку банкам, обеспечивая сохранность их кассовых резервов. Однако банки обращаются к ЦБ РФ лишь в крайнем случае (например, вследствие невозможности получения кредита другим способом), так как кредиты данное учреждение предоставляет по ставке выше рыночной.

Также в круг обязанностей ЦБ РФ входит поддержание внешних условий для стабильного функционирования кредитных организаций, не оказывая влияния на их оперативную деятельность за исключением случаев, предусмотренных федеральными законами.

Наряду с осуществлением своей основной деятельности ЦБ РФ предоставляет кредитным организациям услуги консультационного характера, а также в соответствии с законом рассматривает предложения по регулированию банковской деятельности. За счет обязательных отчислений кредитных организаций формируется страховой фонд, который формируется на условиях и в порядке, которые определяет ЦБ РФ. Цель создания такого фонда заключается в обеспечении надежности банковской системы страны.

Необходимо отметить, что ЦБ РФ подлежит ликвидации только на основании вступления в силу соответствующего федерального закона, в котором будет оговорен порядок использования его имущества. [5, с. 798]

Таким образом, в интересах ЦБ РФ реализовать проведение такой бюджетной политики, которая будет призвана обеспечить сбалансированность и устойчивость бюджетной системы на долгосрочную перспективу. Также ЦБ РФ необходимо моментально реагировать на гиперизменчивые экономические условия,корректируя свои дальнейшие действия в разрезе денежно-кредитной политики. В свете вышесказанного ЦБ РФ необходимо продолжать придавать широкой огласке цели, оценки состояния и перспективы развития денежно-кредитной политики страны с последующей 
аргументацией принятых решений и действий в данной области посредством средств массовой информации. Развитие такого информационного взаимодействия между ЦБ РФ и общественностью будет создавать предпосылки для обеспечения доверия к ЦБ РФ и уверенности в правильности проводимой денежно-кредитной политики.

Данные действия ЦБ РФ будут вносить огромный вклад в поддержание финансовой и общей макроэкономической стабильности, создавая подходящую обстановку для экономического роста.

Так, эффективная реализация вышеназванных мер по укреплению экономической ситуации Российской Федерации и создания условий для повышения эффективности ее регулирования при помощи действий ЦБ РФ приведет к активизации финансовой и социальной сферы и ее совершенствованию в будущем.

$$
* * *
$$

1. Денежно-кредитная политика центральных банков: анализ, опыт, перспективы /Коллектив авторов экономического факультета МГУ им. М.В. Ломоносова. - М.: РГ-Пресс, 2013. - 224 с.

2. Звонова, Е.А. Организация деятельности центрального банка / под ред. Е.А. Звонова. - М.: Инфра-М, 2014.- 400 c.

3. Официальный сайт Банка России [Электронный ресурс] // Режим доступа http://www.cbr.ru/.

4. Манушин, Д.В. Определение этапов антикризисного управления в России на макроэкономическом уровне / Д.В. Манушин // Экономический анализ: теория и практика. - 2014. - №20. - с. 13-23.

5. Голикова, Ю.С. Организация деятельности Центрального банка / Ю.С. Голикова, М.А. Хохленкова. М.: Инфра-М, 2012.- 798 c.

\section{Ильяшенко В.В. \\ Влияние валютного курса рубля на инфляционные процессы в российской экономике \\ Уральский государственный экономический университет (Россия, Екатеринбург)}

doi: 10.18411/sr-10-08-2017-07

idsp: 000001:sr-10-08-2017-07

\section{Аннотация}

В статье рассматривается влияние валютного курса рубля на развитие инфляции в российской экономике. Определены направления этого воздействия на динамику цен. Показана значительная зависимость валютного курса рубля от конъюнктуры мировых цен на нефть. Проанализирована взаимосвязь динамики темпов инфляции и обменного курса рубля в России.

Ключевые слова: инфляция, валютный курс, девальвация национальной валюты, валютные резервы, мировые цены.

На развитие инфляционных процессов влияют внешнеэкономические связи страны. В связи с этим наряду с традиционными типами инфляции, которые анализируются в экономической литературе: спроса и издержек, мы выделяем внешнеэкономическую инфляцию. В качестве основных показателей, которые ее характеризуют, выступают валютный курс, чистый экспорт страны и таможенные пошлины. Рассмотрим влияние валютного курса на инфляцию в экономике России.

Динамика обменного курса национальной валюты влияет на темпы инфляции многосторонне через различные факторы инфляции.

В частности, в условиях, когда существует дефицит государственного бюджета, правительство может осуществлять его покрытие с помощью различных источников: эмиссии денег, использования кредитных ресурсов или валютных резервов. При этом механизм установления обменного курса национальной валюты и его изменение влияют 
на возможности финансирования дефицита бюджета и развитие инфляционных процессов.

Как известно, различают системы фиксированных (твердых), плавающих и управляемо плавающих валютных курсов. При фиксированном обменном курсе центральному банку необходимо для его поддержания осуществлять обмен национальной валюты на иностранную, используя имеющиеся валютные резервы. Покупка иностранной валюты и рост валютных резервов ведут к увеличению предложения национальных денег, и наоборот, продажа иностранной валюты и снижение валютных резервов, к его уменьшению. При использовании системы плавающих валютных курсов центральный банк не обязан поддерживать определенный обменный курс, который устанавливается в результате действия механизма спроса и предложения на валютном рынке. Однако в действительности центральные банки различных государств, в зависимости от экономической ситуации в стране, участвуют в операциях на валютном рынке, влияя на изменение ценности национальной валюты и при плавающем валютном курсе. При твердом валютном курсе обменный курс является экзогенной переменной, а денежная масса - эндогенной величиной, определяемой внутренними условиями макроэкономического равновесия на денежном рынке. При плавающем валютном курсе соотношение между валютным курсом и массой денег противоположное.

Увеличение предложения национальных денег, при прочих равных условиях, способствует повышению курса иностранной валюты. В этом случае при использовании системы фиксированного валютного курса центральному банку необходимо осуществлять валютную интервенцию, продавая часть своих валютных резервов, для предотвращения девальвации национальной валюты и развития инфляционных процессов. Если национальная валюта обесценивается при возрастании предложения денег в условиях системы плавающих валютных курсов, а центральный банк не проводит валютную интервенцию, то по мере снижения курса национальной валюты будут пропорционально увеличиваться цены импортных, а затем и отечественных товаров.

Повышение цен ведет к увеличению трансакционного спроса на деньги со стороны хозяйствующих субъектов. Для поддержания курса национальных денег центральный банк может продавать их на валютном рынке, приобретая иностранную валюту. При этом удовлетворяется спрос на национальные деньги населения, и возрастают валютные резервы центрального банка. Однако рост цен, связанный с девальвацией, влияет на снижение покупательной способности денег, уменьшение реальных денежных остатков субъектов экономики и их богатство.

Девальвация национальной валюты является одной из важных причин внешнеэкономической инфляции в стране. Прежде всего это проявляется через увеличение цен на импортные товары, даже если за границей цены на них не изменились. При прочих равных условиях выгоднее становится экспорт продукции, что способствует увеличению вывоза товаров из данной страны и сокращению их внутреннего предложения. Если в экспорте страны преобладают материальные ресурсы, то снижение курса национальной валюты означает в первую очередь увеличение вывоза сырьевых ресурсов, так как продукция обрабатывающей промышленности, как правило, является неконкурентоспособной на мировом рынке. Совокупное предложение материальных ресурсов снижается, что объективно влияет на рост внутренних цен и развитие инфляционных процессов.

С одной стороны, девальвация рубля стимулирует увеличение российского экспорта, ведет к увеличению доходов экспортоориентированных отраслей, a следовательно, и поступлений в государственный бюджет; с другой стороны, она сдерживает импорт высокопроизводительной техники, способствует дальнейшему вывозу капитала, препятствует увеличению инвестиций и экономическому росту. Из-за низкого курса рубля повышается удельный вес расходов федерального бюджета, направляемых на 
обслуживание государственного внешнего долга, и уменьшаются возможности финансирования национальной экономики, но главное - снижаются доходы населения.

На динамику валютного курса рубля в РФ значительное влияние оказывает конъюнктура мировых цен на экспортируемые из страны товары, так как их динамика ведет к изменению величины поступления валютной выручки в Россию и к снижению доходов государственного бюджета. Так, низкие мировые цены на топливноэнергетические и сырьевые ресурсы вели к падению курса рубля и увеличению темпов инфляции в России (так было, например, в 1998 г., когда мировые цены на нефть снизились в 1,4 раза). Напротив, существенное повышение мировых цен на нефть в 1999-2004 гг. сопровождалось сначала замедлением темпов роста курса доллара и, соответственно, снижения номинального курса рубля в 1999-2002 гг., а в 2003-2004 гг. снижением курса доллара и повышением курса рубля. Аналогичная зависимость наблюдалась и в последние годы. Существенное снижение мировых цен на нефть марки Брент в 2014 г. со 107 дол. в январе до 57 дол. в декабре за баррель повлекло за собой повышение курса долл. к рублю на 71,9\%., а в аналогичные периоды 2015 г. с 49 до 36 дол. - к росту курса доллара еще на 29,5\%. И наоборот, повышение мировых цен в 2016 г. с 34 до 56 дол. - к снижению курса доллара на 6,8\%.

Между темпами инфляции и динамикой обменного курса национальной валюты существует определенная зависимость. В российской экономике она проявлялась достаточно четко на протяжении 1990-х-2000-х годов

(см. таблицу 1).

Таблиия 1.

Динамика темпов инфляции и обменного курса рубля в России в 1994-2016 г2. (на конеи периода)1

\begin{tabular}{|c|c|c|c|}
\hline Год & $\begin{array}{c}\text { Темп инфляции } \\
\text { за период, } \\
\text { определяемый по } \\
\text { ИПц, \% }\end{array}$ & $\begin{array}{c}\text { Номинальный курс } \\
\text { доллара США к } \\
\text { рублю на конец } \\
\text { периода, } \\
\text { р. за дол. США }\end{array}$ & $\begin{array}{c}\text { Изменение курса } \\
\text { доллара к рубл, \% }\end{array}$ \\
\hline 1994 & 215 & 3,55 & 184,0 \\
1995 & 131 & 4,64 & 30,7 \\
1996 & 21,8 & 5,56 & 19,8 \\
1997 & 11,0 & 5,96 & 7,2 \\
1998 & 84,4 & 20,65 & 246,5 \\
1999 & 36,5 & 27,00 & 30,8 \\
2000 & 20,2 & 28,16 & 4,3 \\
2001 & 18,6 & 30,14 & 7,0 \\
2002 & 15,1 & 31,78 & 5,4 \\
2004 & 12,0 & 29,45 & $-7,3$ \\
2005 & 11,7 & 27,75 & $-5,8$ \\
2006 & 10,9 & 28,78 & 3,7 \\
2007 & 9,0 & 26,33 & $-8,5$ \\
2008 & 11,9 & 24,52 & $-6,9$ \\
2009 & 13,3 & 29,38 & 19,8 \\
2010 & 8,8 & 30,24 & 2,9 \\
2011 & 8,8 & 30,48 & 0,8 \\
2012 & 6,1 & 32,20 & 5,6 \\
2013 & 6,6 & 30,37 & $-5,7$ \\
2014 & 6,5 & 32,73 & 7,8 \\
2015 & 11,4 & 56,26 & 29,5 \\
2016 & 12,9 & 72,88 & $-6,8$ \\
& 5,4 & 60,66 & \\
\hline
\end{tabular}

Данные таблицы показывают, что обменный курс рубля к доллару повышался за 23 последних года только в течение 6 лет. При этом 4 года из 6 снижались и темпы инфляции. В остальные годы, когда происходила девальвация рубля, в значительной степени проявлялась не менее важная закономерность: при снижении темпов падения 
курса рубля в основном снижались и темпы инфляции. Такая ситуация наблюдалась в течение 9 лет анализируемого периода. При этом в 1995, 1996, 1997, 1999, 2000, 2002, 2009 гг. уровень инфляции снижался, в 2010 г. не изменился, и только в 2015 г. темпы инфляции возросли. Вместе с тем следует также отметить, что значительное влияние снижения валютного курса рубля на увеличение уровня инфляции в стране однозначно проявлялось в периоды существенной девальвации рубля: в 1998, 2008, 2014 и 2015 гг.

Таким образом, в российской экономике динамика валютного курса рубля является одним из важных факторов, влияющих на развитие инфляционных процессов.

$$
* * *
$$

1. Ильяшенко В.В. Внешнеэкономическая инфляция в российской экономике // Управленец. -2015 г. - № 5 (57). - C. 34-37.

2. Ильяшенко В.В. Инфляция: проблемы теории и практики. - Екатеринбург: Изд-во Урал. гос. экон. унта, 2002. $-200 \mathrm{c}$.

3. Ильяшенко В.В. Макроэкономические и микроэкономические факторы инфляции в трансформируемой экономике России: Автореф. дис. ... д-ра экон. наук. Екатеринбург, 2007. - 47 с.

4. Официальный сайт Федеральной службы государственной статистики. URL: www.gks.ru

5. Официальный сайт Центрального банка PФ. URL: www.cbr.ru

\title{
Харитонов А.В. \\ Роль личных подсобных хозяйств в устойчивом развитии сельских территорий: региональный аспект
}

\author{
Сибирский научно-исследовательский институт \\ экономики сельского хозяйства СФНЦА РАН \\ (Россия, Краснообск)
}

doi: 10.18411/sr-10-08-2017-08

idsp: 000001:sr-10-08-2017-08

\section{Аннотация}

В статье исследована роль личных подсобных хозяйств в устойчивом развитии сельских территорий. Выявлено, что в условиях экономики промышленно-развитого региона личные подсобные хозяйства выступают одним из ключевых факторов устойчивого развития сельских территорий. Данное обстоятельство предопределяет сосредоточить усилия органов государственной власти региона на создании условий для развития личных подсобных хозяйств, включая государственную поддержку.

Ключевые слова: личные подсобные хозяйства, сельские территории, устойчивое развитие, функции устойчивого развития, государственная поддержка.

Современные экономические условия устойчивого развития сельских территорий предопределяют ведущую роль агарной политике. При этом, из многообразия факторов, способствующих устойчивому развитию сельских территорий наиболее важным и действенным является ставка на их внутренний потенциал и его эффективное использование, составным элементом которого являются личные подсобные хозяйства (ЛПХ) населения.

Следует отметить, что внимание к проблемам их социально-экономического развития со стороны официальной власти, экономистов и научной общественности страны уделяется недостаточно, несмотря на то, что Концепцией устойчивого развития сельских территорий определены основные направления до 2020 года.

Основные усилия носят теоретический, иногда точечно-практический характер. Более того, в последние годы обострились: сельская бедность и высокий уровень безработицы; усложнилась демографическая ситуация; обозначилась недостаточная сеть учреждений социальной инфраструктуры, которые оказывают негативное влияние на 
условия жизни населения. Трудовые ресурсы и их воспроизводство, как основополагающий базис экономического развития сельской территории не выполняет данной функции.

Началом перехода к устойчивому развитию Российской Федерации, послужил Указ Президента РФ №440 от 01.04.1996 года «О концепции перехода Российской Федерации к устойчивому развитию», который определил в качестве первостепенных задач сбалансированное решение социально-экономических проблем, сохранение природоохранного потенциала и благоприятную окружающую среду с целью удовлетворения потребностей ныне живущих и будущих поколений людей[1;7]. Для каждой сельской территории проблемы экономического, социального, демографического и иного характера должны решаться комплексно, в следствии того, что именно они выступают в качестве объектов внедрения принципов и механизмов в российскую практику устойчивого развития.

Устойчивое развитие подразумевает стабильность развития сельского сообщества, включающее выполнение следующих функций:

1) народнохозяйственную, связанную с производством продовольственных товаров, сельскохозяйственного сырья, другие несельскохозяйственные товары и услуги, общественные блага, предоставлением рекреационных услуг, сохранность сельской культуры и образа жизни селян, осуществление социального контроля над территорией и исторически освоенного ландшафта; 2) социальную - повышение уровня и качества жизни населения и его воспроизводство; 3) экологическое равновесие в биосфере и его сохранение.

Отдельного внимания требуют сельские территории в промышленно-развитых регионах, для которых характерно невысокая доля населения занятого в сельскохозяйственном производстве в сравнении с добывающими, перерабатывающими и другими отраслями экономики.

Таким регионом является Кемеровская область, сельскому хозяйству которой присущ инерционный тип развития и оно функционирует в условиях интенсивно развивающейся угольной, металлургической и других отраслей. Основными факторами оказывающими значительное отрицательное воздействие на аграрную отрасль является: существенное колебание конъюкруры рынка, деградация земельных ресурсов, старый технологический уклад развития отрасли, незавершенные институциональные преобразования в сельском хозяйстве [3;5].

Для регионов такого типа, где личные подсобные хозяйства показали достаточно высокую устойчивость в кризисных ситуациях и акцент производства сельскохозяйственной продукции за последние годы сместился в их сторону, они в устойчивом развитии сельских территорий выступают как один из ключевых факторов.

Одновременно, «... владельцы личных подсобных хозяйств, выступая главными товаропроизводителями сельскохозяйственной продукции имеют ограниченный доступ к средствам производства. Не имеющие четкой снабженческо-сбытовой структуры владельцы личных подсобных хозяйств оказываются вовлеченными в замкнутый круг бартерных отношений, они вынуждены получать материально-технические ресурсы в обмен на производимую продукцию на крайне невыгодных условиях» [4].

Регламентация деятельности личных подсобных хозяйств приводится в соответствии с федеральным законом «О личном подсобном хозяйстве" №112-Ф3 от 07.07.2003 года, где под личным подсобных хозяйством понимается непредпринимательская деятельность в сфере производства и переработки продукции сельского хозяйства [8]. Законом личное подсобное хозяйство определяется как совместно осуществляемое гражданином либо гражданином и проживающими с ним совместно лицами и ведение личного хозяйства на участке земли предоставленном и(или) приобретенным, с целью удовлетворения личных потребностей. 
Следует отметить, что граждане, занятые производством и реализацией продукции сельского хозяйства, ее переработкой в личном подсобном хозяйстве не относятся к предпринимателям, а их деятельность - к предпринимательской, следовательно и доход полученный от такой деятельности не облагается налогом. В какой-то мере признание ведение ЛПХ непредпринимательской деятельности на федеральном уровне является поддержкой данного вида хозяйства. Во избежание спекуляций и попыток скрыть предпринимательскую сельскохозяйственную деятельность подвести под условия ЛПХ, в законе прописано, что максимальные общий размер участков земли, находящихся одновременно у гражданина на праве собственности и(или) ином праве не должен превышать 0,5 га.

В 2016 году на территории Кемеровской области насчитывалось 153,0 тысячи личных подсобных хозяйств против 154,6 тысяч в 2011 году. Снижение составило - 1,03 процента, в следствии снижения общей численности сельского населения на 21 тысячу человек (на 5,2 процента) за этот период. Немаловажным является устоявшаяся тенденция старения сельского населения, что снижает число лиц потенциально способных вести личное подсобное хозяйство.

Следует отметить, что посевные площади в личных подсобных хозяйствах увеличились к 2011 году на 15 тысяч гектар и составили в 2016 году -334,4 тысячи гектар. Поголовье крупного рогатого скота в 2016 году насчитывало 16,1 тысячи голов, против 14,9 тысячи голов в 2011 году, рост составил 7,5 процента. Производство валовой продукции сельского хозяйства в области претерпела незначительные изменения: от 44,2 в 2011 году до 47,3 процента в 2016 году. За период с 2011 по 2016 годы объем производства сельскохозяйственной продукции в ЛПХ вырос на 57,6 процента и составил 26396,0 млн. рублей. Следует отметить, что темпы роста производства продукции в ЛПХ самые высокие, так ближайшие конкуренты - сельскохозяйственные организации за тот же период увеличили свой объем лишь на 39,98 процента. За последние десять лет, личными подсобными хозяйствами области производится более 75 процентов овощей и картофеля [2;6].

Показательно, что в неурожайном 2012 году наблюдался спад объема производства сельскохозяйственной продукции как в целом, так и по каждой категории хозяйств, за исключением ЛПХ. Данный факт подчеркивает более высокую устойчивость в условиях неблагоприятной внешней среды данного типа хозяйства и их роли в продовольственном обеспечении населения Кемеровской области.

Равное соотношение объемов производства продукции животноводства и растениеводства на территории региона является характерной чертой всего сельскохозяйственного производства. Но если сельскохозяйственные организации занимаются в основном животноводством, то лидерство в растениеводстве принадлежит ЛПХ. Это связано, прежде всего, с наличием земельных участков у жителей городов и поселков в садоводческих товариществах, используемых в качестве ЛПХ.

В результате, помимо сельских жителей, значительная часть горожан на своих садовых участках, находящихся на некотором отдалении от основного места жительства, самостоятельно обеспечивают себя продукцией сельского хозяйства, тем самым внося свой вклад в показатели производства сельскохозяйственной продукции Кемеровской области в целом.

Исходя из значимости, которую играют ЛПХ в продовольственном обеспечении населения региона и его экономики в целом, органы государственной власти Кемеровской области активно поддерживают данную форму хозяйствования, оказывающую положительное влияние на развитие сельских территорий. В связи с этим, в Кемеровской области был прият и действует закон «О государственной поддержке личных подсобных хозяйств в Кемеровской области» №95-О3 ОТ 19.11.2001 года [9].

Государственная поддержка развития личных подсобных хозяйств в соответствии с законом, обеспечивает правовые и организационно-экономические условия 
содействующие занятости сельских жителей, реализует социальные гарантии, установленные Конституцией РФ, способствует повышению доходов сельских семей, увеличивает производство продукции сельского хозяйства, позволяет вовлекать в рыночный оборот продовольствие и сырье, что в конечном итоге, окажет положительное воздействие на продовольственное обеспечение не только учреждений финансируемых из местного бюджета и областного, но и всего населения.

В соответствии с законом: 1) гражданам, ведущим личное подсобное хозяйство, возмещается часть банковских процентов уплаченных за пользование кредитными ресурсами; 2) в соответствии с целевыми региональными программами, для граждан занимающихся ведением личного подсобного хозяйства, предоставляются займы.

Государственная поддержка личных подсобных хозяйств в виде финансирования мероприятий утвержденных региональными программами обеспечивается средствами бюджета области.

Исходя из проведенного анализа, следует вывод о высокой значимости личных подсобных хозяйств в устойчивом развитии такого промышленного региона, как Кемеровская область.

Это связано с тем, что основная часть сельских территорий находится вблизи залежей полезных ископаемых, а население профессионально занято не в традиционной для села отрасли - «Сельское хозяйство», а занято в отраслях промышленности, прежде всего угледобывающей. Эффективность ЛПХ в сравнении с другими формами сельскохозяйственного производства проявилась в условиях неурожайного 2012 года, когда ЛПХ не только сумели выстоять, но и показать высокие темпы прироста производства продукции. Государство, особенно на региональном уровне активно занимается поддержкой и развитием ЛПХ, принимает законы, направленные на его поддержание и развитие.

Учитывая значимость ЛПХ в продовольственном обеспечении населения, особенно в условиях «импортозамещения», меры предпринимаемыми властями в этом направлении сегодня недостаточны. Территориальная особенность развития экономики региона можно оценивать как преимущества для центральных и южных сельских территорий, с другой стороны, для хозяйств расположенных в отдалении от крупных городов, существуют проблемы со сбытом продукции, что сказывается на их развитии. При этом, личными подсобными хозяйствами производится в пределах 50 процентов продукции сельского хозяйства, что сохраняет основу образа жизни сельских жителей[6;10].

Именно это обстоятельство, на наш взгляд, предопределяет направление усилий региональной власти на создании условий в реализации излишков произведенной продукции личных подсобных хозяйств, налаживании прямого взаимодействия между продавцом и покупателем, защиту от навязанных «посреднических услуг». Что касается производства продукции на дачных участках горожан, то для них особенно актуальна проблема грабежей в зимний период. Именно по этой причине многие жители городов отказываются от их владения. Благоприятные условия, направленные на устойчивое функционирование личных подсобных хозяйств, активное встраивание их в рыночный механизм, можно рассматривать как эффективный инструмент устойчивого развития сельских территорий.

$$
\text { *** }
$$

1. Указ Президента РФ от 1 апреля 1996 г. № 440 « концепции перехода Российской Федерации к устойчивому развитию»»" Режим доступа: http://base.consultant.ru/cons/cgi/online.cgi?base=EXP\&n=233558\&req=doc

2. Агропромышленный комплекс муниципальных районов. 2012-2016 гг.- Обзорно- статистическое издание /Кемеровостат- Кемерово, 2017. -139 с. 
3. Бондарев Н.С., П.Д.Косинский, И.В.Щетинина, Г.С.Бондарева/ Теоретико-методологические и прикладные аспекты институциональных преобразований в сельском хозяйстве /под ред. академика РАН П.М.Першукевича - Томск: Изд-во Том. ун-та, 2017. -340с.

4. Борейша В.Г. Роль личных подсобных хозяйств в устойчивом развитии сельских территорий промышленного региона//Научный альманах. - 2015.- № 10-1 (12).- С. 71-76.

5. Борейша В.Г. Экологические последствия развития угольной промышленности для сельских территорий: региональный аспект. В сборнике: Экологические проблемы промышленно развитых и ресурсодобывающих регионов: пути решения; сборник трудов Всероссийской молодежной научнопрактической конференции, 2016. - С.5.

6. Воздействие факторов производства на развитие сельского хозяйства региона/Харитонов А.В., Косинский П.Д., Бондарев Н.С.//АПК: экономика и управление. - 2016. -№12. -С.74-80.

7. Лейбутина Е.В. Роль сельского хозяйства в устойчивом развитии сельских территорий региона. В сборнике: Перспективы развития науки и образования сборник научных трудов по материалам Международной научно-практической конференции: в 13 частях. 2015. С. 109-113.

8. Лейбутина Е.В. К вопросу устойчивого развития сельских территорий промышленного региона. В сборнике: Современное общество, образование и наука: сборник научных трудов по материалам Международной научно-практической конференции: в 9 частях. - 2014. -С.65-69.

9. Федеральный закон от 7 июля 2003 г. № 112-Ф3 "О личном подсобном хозяйстве" - Режим доступа: http://base.garant.ru/12131702/

10. Закон Кемеровской области от 19 ноября 2001 года № 95-О3 «О государственной поддержке личных подсобных хозяйств в Кемеровской области» - Режим доступа: http://www.ako.ru/ZAKON/viewzakon.asp?C23802=On

11. Роль сельского хозяйства в реализации политики импортозамещения и поддержании продовольственной безопасности региона/ Чупрякова А.Г., Косинский П.Д. //Международный журнал прикладных и фундаментальных исследований. -2014. -№12. Ч.2.-С.208-211. 


\title{
РАЗДЕЛ ІV. ЮРИСПРУДЕНЦИЯ
}

\author{
Деманова С.В. \\ Гуманитарное образование иностранных граждан в Российской Федерации: \\ проблемы реализации \\ Саратовский нащиональный исследовательский государственный университет \\ имени Н.Г. Чернышевского \\ (Россия, Саратов)
}

doi: $10.18411 / \mathrm{sr}-10-08-2017-09$

idsp: 000001:sr-10-08-2017-09

\section{Аннотация}

В представленной статье обозначены некоторые проблемные вопросы, связанные с получением гуманитарного образования иностранными гражданами в Российской Федерации. Важным условием получения высшего образования иностранными гражданами является знание русского языка. Однако практика реализации получения высшего образования иностранными студентами на юридическом факультете СГУ по ряду направлений подготовки и специальностям показала, что существуют и иные проблемы, связанные непосредственно с реализацией учебного процесса, например, прохождением различных видов практик.

Ключевые слова: гуманитарное образование, образовательные организации высшего образования, иностранные граждане, русский язык, ФГОС ВО, учебный процесс.

\section{Abstract}

The article highlights some topical issues of receiving a liberal education by foreign citizens in the Russian Federation. The knowledge of the Russian language is an essential condition of getting higher education by foreign citizens. However, the practice of implementation of getting higher education by foreign students at the faculty of law of Saratov State University in a number of fields of study and majors has shown that there are other problems connected with the implementation of the educational process, for example, various types of apprenticeships.

Keywords: liberal education, higher education institution, foreign citizens, the Russian language, Federal State Education Standards, educational process.

Ежегодно более 100 тыс. иностранных студентов прибывают в Российскую Федерацию, чтобы получить образование в образовательных организациях высшего образования. Данное обстоятельство обусловлено тем, что Россия является одним из лидеров в математическом и естественнонаучном образовании [1]. Так, например, четыре ведущих вуза вошли в сотню лучших мировых университетов по версии предметных рейтингов Times Higher Education (МГУ имени М.В. Ломоносова, Московский физикотехнический институт (МФТИ), Высшая школа экономики (НИУ ВШЭ), Университет ИТМО) [2].

Что касается гуманитарного образования, то и в данной области знания наметилась тенденция по увеличению экспорта образовательных услуг. Мы полностью поддерживаем точку зрения И.М. Шеиной, которая утверждает, что гуманитарное образование призвано не только обеспечивать передачу научных знаний и представлений новым поколениям, но и формировать их ценностные ориентиры в нравственном измерении. Поэтому гуманитарное знание является важной составляющей фундаментального образования, позволяющего сформировать личность с широким кругозором [3]. 
Иностранные граждане имеют право на получение высшего образования в Российской Федерации как за счет бюджетных средств, так и за счет физических или юридических лиц, что установлено Федеральным законом от 29.12.2012 N 273-Ф3 «Об образовании в Российской Федерации» [4, п. 3 ст. 78].

Так, численность иностранных студентов в России в 2016 году составила более 237 тыс. чел. Необходимо отметить, что большая часть контингента иностранных студентов (около 80\%) приходится на страны бывшего СССР[5].

Законодательное регулирование получения высшего образования иностранными гражданами в Российской Федерации имеет ряд особенностей, которые устанавливаются не только национальным законодательством об образовании, но и международными договорами.

Необходимо сказать, что Российская Федерация является участницей международных договоров о сотрудничестве в области образования более чем с сорока зарубежными странами. Так, например, участниками соглашения об углублении интеграции в экономической и гуманитарной областях являются Республика Беларусь, Республика Казахстан, Кыргызская Республика, Республика Таджикистан и др.[6].

Саратовский государственный университет имени Н.Г. Чернышевского также вовлечён в международное образовательное и научное пространство. В связи с присвоением СГУ категории «национального исследовательского университета» существенно расширилась сфера международного сотрудничества. СГУ имеет договоры о сотрудничестве с зарубежными университетами Европы, Азии и Америки.

К примеру, в СГУ в настоящее время обучаются 767 иностранных студентов из 42 стран. География прибытия иностранных студентов достаточно обширна и включает такие страны как Словения, Камерун, Венесуэла, Болгария, Нидерланды, Мозамбик, Иордания, Ирак, Туркменистан, Казахстан и др. (463 иностранных студента - из стран Ближнего зарубежья, 304 - из стран Дальнего зарубежья) [7, с. 74-75]. Иностранные студенты получают высшее образование по программам бакалавриата, специалитета, магистратуры и программам подготовки кадров высшей квалификации.

Важным условием получения высшего образования иностранными гражданами является знание русского языка. Всех иностранных граждан, которые решили получить высшее образование в Российской Федерации, условно можно разделить на несколько групп. Первая группа - это иностранные граждане, которые владеют русским языком и имеют соответствующий сертификат о прохождении государственного тестирования по русскому языку как иностранному. Вторая группа - это иностранные граждане, владение русским языком которых подтверждено документом об образовании. Например, таким является аттестат о среднем общем образовании. Третья группа - это иностранцы, которые владеют русским языком, но не имеют соответствующего документа. Иностранные граждане (абитуриенты), которые относятся к первой и второй группам, допускаются к вступительным испытаниям в образовательные организации высшего образования.

Абитуриенты из третьей группы должны в обязательном порядке пройти тестирование на знание русского языка как иностранного. После успешной сдачи и получения сертификата абитуриенты также допускаются к вступительным испытаниям.

Как говорилось ранее, в основном иностранные абитуриенты прибывают из стран бывшего СССР. Следует отметить, что по оценкам специалистов-филологов, языковая ситуация на постсоветском пространстве, где до распада СССР русский язык был общепризнанным языком межнационального общения, весьма противоречива. К странам, в которых судьба русского языка не вызывает беспокойство, относятся Республика Беларусь, Казахстан и Кыргызстан [8, с.6]. 
В соответствии с приказом Министерства образования и науки Российской Федерации от 01.04.2014 № 255 «Об утверждении уровней владения русским языком как иностранным языком и требований к ним» устанавливаются следующие уровни владения русским языком как иностранным: элементарный (ТЭУ/А1); базовый для трудящихся мигрантов (ТБУМ/А1); базовый (ТБУ/А2); первый (ТРКИ-І/В1); второй (ТРКИ-ІІ/В2); третий (ТРКИ-III/C1); четвертый (ТРКИ-IV/C2) [13]. Необходимо отметить, что для получения высшего образования иностранными гражданами в образовательных организация высшего образования Российской Федерации уровень владения русским языком как иностранным должен быть не менее В1. Уровень владения русским языком, соответствующий уровню В1, так называемый пороговый уровень (Threshold Level), как правило, достигается выпускниками подготовительных факультетов образовательных организаций для иностранных граждан после годичной специальной языковой подготовки. Такие абитуриенты должны уметь читать небольшие тексты, писать текст из двадцати предложений, понимать короткие диалоги, уметь участвовать в диалогах в достаточно широком круге ситуаций, формулировать собственное мнение и др. [9].

К особой группе абитуриентов относятся иностранные граждане, которые имеют A1, элементарный уровень (Breakthrough Level) владения языком, либо А2, предпороговый (базовый) уровень (Waystage Level). При таком владении русским языком иностранным гражданам необходимо пройти дополнительное обучение. Однако по усмотрению приемной комиссии образовательной организации иностранные граждане могут быть зачислены на первый курс с обязательным посещением дополнительных занятий по русскому языку с оплатой стоимости образовательных услуг для достижения уровня В1.

К сожалению, приходится констатировать тот факт, что не всегда абитуриенты, имеющие соответствующий сертификат, владеют русским языком как иностранным на достаточном уровне. Это ведет к трудностям в усвоении лекционного материала, участии в семинарских и лабораторных занятиях, а также в выполнении самостоятельной работы.

Практика реализации получения высшего образования иностранными гражданами на юридическом факультете СГУ по направлению подготовки «Юриспруденция» и таким специальностям как «Таможенное дело» и «Судебная экспертиза» показала, что существует и иные проблемы, связанные не только с уровнем владения русского языка, но и непосредственно с реализацией учебного процесса, например, прохождением различных видов практик. Как справедливо отмечают Е.В. Бердникова и С.В Деманова, практикоориентированность стала нормой образовательной деятельности в вузе, решая установки, закладываемые интересами и требованиями предприятий и организаций. Практика является обязательным элементом учебного процесса, способствующим, с одной стороны, отработке и закреплению знаний, полученных в ходе теоретического обучения, а, с другой стороны, - получению необходимых практических навыков для дальнейшей успешной профессиональной деятельности[10, с.360].

Так, например, в ФГОС ВО по специальности «Судебная экспертиза» одним из требований, обязательных при реализации основных профессиональных образовательных программ высшего образования, является прохождение различных видов практик (учебная, производственная) и научно-исследовательская работа, которые относятся к базовой части программы и являются обязательными для освоения обучающимися. Рабочий учебный план данной специальности включает различные типы учебной и производственной практик. Так, например, ознакомительная практика направлена на получение первичных профессиональных умений и навыков научно-исследовательской деятельности. В рамках производственной практики предусмотрены экспертная и преддипломная практики, которые направлены на получение не только профессиональных умений, но и опыта профессиональной деятельности. Учитывая вид профессиональной деятельности, который реализуется в СГУ, а именно экспертная, все виды практик по данной специальности обучающиеся проходят в Экспертно- 
криминалистическом центре Главного управления Министерства внутренних дел Российской Федерации по Саратовской области (далее - Центр). Кроме того, практические занятия по такой учебной дисциплине как «Криминалистическое исследование веществ, материалов и изделий» также проводятся на базе Центра. Необходимо отметить, что Экспертно-криминалистический центр является структурным подразделением полиции, где осуществляется производство различных видов экспертиз и исследований. Например, такие исследования как дактилоскопические, трасологические, почерковедческие, баллистические, исследования холодного и метательного оружия, технико-криминалистические исследования документов и др., по которым Центр имеет соответствующих специалистов, условия и методики для выполнения данных исследований [11].

Таким образом, использование в учебном процессе материально-технической базы Центра, опыта и знаний действующих сотрудников позволяет отработать и закрепить теоретические знания и получить необходимые практические навыки. Внедрение практической составляющей образовательного процесса полностью согласуется с современной парадигмой высшего образования. Однако практика реализации таких занятий с обучающимися, имеющими гражданство иностранных государств, сопряжена с рядом трудностей, которые связаны с обеспечением режима секретности в органах внутренних дел Российской Федерации [12].

Подобная ситуации в прохождении производственной практики (таможенная 1, таможенная 2 , преддипломная) иностранными студентами складывается и при реализации программы специалитета по специальности «Таможенное дело». Так как эти практики студенты проходят в основном на Саратовской таможне и таможенных постах (Саратовский, Энгельский, Балаковский), доступ иностранных студентов в данные организации также ограничен.

Таким образом, учитывая специфику получения высшего образования иностранными гражданами по ряду гуманитарных направлений подготовки и специальностям, на этапе приемной кампании необходимо вести разъяснительную работу с абитуриентами, предоставляя возможность ознакомления с ФГОС ВО и рабочими учебными планами, а также объяснять особенности учебного процесса (проведение различных видов практик, лабораторных и практических занятий и др.). Уровень владения русским языком должен быть таким, чтобы не только обеспечить иностранному студенту процесс адаптации в новой социоязыковой и культурной среде, знакомство с национальными обычаями и традициями, но и сформировать коммуникативно-речевые компетенции в чтении, аудировании, письме и говорении. Самое главное - изучение не только общепрофессиональных дисциплин, но и специальных в соответствии с ФГОС ВО по соответствующему направлению или специальности.

$$
* * *
$$

1. Прим. автора: TIMSS (Trends in Mathematics and Science Study) - международное исследование качества математического и естественнонаучного образования, проводимое Международной ассоциацией по оценке учебных достижений (IEA). В рамках исследования TIMSS оценивается общеобразовательная подготовка учащихся 4-х и 8-х классов по математике и естественнонаучным предметам, а также подготовка учащихся 11-х классов, изучающих углубленный профильный курс математики и физики. В исследовании принимают участие более 50 стран. Минрстерство образования и науки Российской Федерации [Официальный сайт]. URL: http:// минобрнауки.рф/пресс-центр/9482 (дата обращения 03.08.2017).

2. Министерство образования и науки Российской Федерации [Официальный сайт]. URL: http://минобрнауки.рф/пресс-центр/8843 (дата обращения 03.08.2017).

3. Шеина И.М. Гуманитарное образование в современном обществе // Международный открытый электронный журнал Higher Education Discovery [Электронный pecypc]. URL: http://www.akvobr.ru/gumanitarnoe_obrazovanie_v_sovremennom_obshestve.html (дата обращения 03.08.2017).

4. Об образовании в Российской Федерации: Федеральный закон от 29.12.2012 № 273-Ф3 (ред. от 01.05.2017, с изм. от 05.07.2017) // СЗ РФ. 2012. № 53 (ч.1). Ст. 7598; 2017. №18. Ст.2670. 
5. $36 \%$ от общего числа студентов из бывших республик Советского Союза приходится на Казахстан; $11 \%$ - Узбекистан; 11\%-Украина; 9\%- Туркменстан; 8\% - Республика Беларусь. См.: Академическая мобильность иностранных студентов в России // Факты образования. Выпуск № 7 (июль 2016 г.) Высшая школа экономики. Национальный исследовательский университет.

6. О предоставлении равных прав гражданам государств - участников Договора об углублении интеграции в экономической и гуманитарной областях от 29 марта 1996 года на поступление в учебные заведения: Соглашение между Правительством Республики Беларусь, Правительством Республики Казахстан, Правительством Кыргызской Республики и Правительством РФ от 24.11.1998 // Бюллетень международных договоров. 2000. № 3.

7. Отчет о результатах самообследования ФГБОУ ВО «СГУ имени Н.Г. Чернышевского» [Сайт]. URL: http://www.sgu.ru/sites/default/files/documents/2017/othet o samoobsledovanii 19.04.2017.pdf 0.pdf (дата обращения 03.08.2017).

8. Вербицкая Л.А. Русский язык в России и за ее пределами // Мир русского слова. № 3. 2014. С. 6.

9. Министерство образования и науки Российской Федерации. Российское образование для иностранных граждан.URL: http://www.russia.edu.ru/rus/levels/ (дата обращения 03.08.2017).

10. Бердникова Е.В., Деманова С.В. Практика как обязательный элемент образовательного процесса в вузе: проблемы нормативного обеспечения // Известия Саратовского университета. Новая серия. Серия: экономика, Управление. Право. 2016. Том 16. Номер 3. С. 360-365.

11. Главное управление МВД России по Саратовской области [Официальный сайт Министерства внутренних дел Российской $\quad$ Федерации]. https://64.мвд.pф/gumvd/Struktura_GU_MVD/Apparat_Glavnogo_upravlenija/ekcgu (дата обращения 28.07.2017).

12. Прим. автора: В соответствии с требованиями Инструкции по обеспечению режима секретности в органах внутренних дел Российской Федерации утвержденной МВД России от 11.03.2012 № 015, прием иностранных граждан на режимной территории органа внутренних дел может проводиться в исключительных случаях, после предварительного согласования с УФСБ России.

13. Об утверждении уровней владения русским языком как иностранным языком и требований к ним: Приказ Минобрнауки России от 01.04.2014 N 255 (Зарегистрировано в Минюсте России 17.06.2014 N 32701) // Рос. газ. N 136. 2014. 20 июня.

\section{Кажибаева Г.Е. \\ Юридические определения коррупции, ее виды и формы}

Многопрофильный колледж гражданской защчи-ты (Казахстан, Кокшетау)

doi: $10.18411 / s r-10-08-2017-10$

idsp: 000001:sr-10-08-2017-10

\section{Аннотация}

В данной статье рассматривается феномен коррупции. Основные направления антикоррупционной деятельности. Юридические определения коррупции, ее виды и формы. Применительно к пониманию феномена коррупции существуют разнообразные методологические подходы. Ее издревле рассматривали в нескольких аспектах социальном, политическом, криминологическом, правовом.

Ключевые слова: коррупция, феномен коррупции, антикоррупционная деятельность, юридические определения коррупции, виды и формы коррупции.

\section{Abstract}

In this article the corruption phenomenon is considered. Main directions of anticorruption activity. Legal definitions of corruption, her types and forms. In relation to understanding of a phenomenon of corruption there are various methodological approaches. She was considered since ancient times in several aspects - social, political, criminological, legal.

Keywords: corruption, corruption phenomenon, anti-corruption activity, legal definitions of corruption, types and forms of corruption.

Коррупция - социальный феномен, порождение общества и общественных отношений. Возникновение и существование коррупции становится возможным с 
момента обособления функций управления в общественной и хозяйственной деятельности, поскольку именно в этом случае у должностного лица (управленца) появляется возможность распоряжаться ресурсами и принимать решения не в интересах общества, государства, а исходя из своих личных корыстных побуждений. Таким образом, коррупция выступает как сложное социально-политическое явление, которое зародилось в глубокой древности и существует в настоящее время - при изменении форм проявления коррупции, ее объемы не сокращаются.

История коррупции как сложного, многогранного явления не уступает по древности истории человеческой цивилизации. Ее возникновение относится ко времени формирования первых классовых обществ и государственных образований. Первое упоминание о коррупции в системе государственной службы нашло отражение в архивах Древнего Вавилона XXIV века до н. э. Царь Лагаша Урукагина реформировал государственное управление с целью пресечения злоупотреблений чиновников и судей.

Известное древнелатинское изречение гласит: «Do ut facies» - «Даю, чтобы сделал» .

Коррупция в современном обществе представляет собой социальный институт, элемент системы управления, тесно взаимосвязанный с другими социальными институтами - политическими, экономическими, культурными. Об институционализации коррупции свидетельствуют:

- выполнение ею ряда социальных функций - упрощение административных связей, ускорение и упрощение принятия управленческих решений, консолидация и реструктуризация отношений между социальными классами и группами, содействие экономическому развитию путем сокращения бюрократических барьеров, оптимизация экономики в условиях дефицита ресурсов и др.;

- наличие вполне определенных субъектов коррупционных взаимоотношений, распределение социальных ролей;

- наличие определенных правил игры, норм, известных субъектам коррупционных действий;

- сложившиеся сленг и символика коррупционных действий;

- установившаяся и известная заинтересованным лицам такса услуг.

Коррупция в немалой степени ограничивает свободное действие экономических законов и снижает престиж страны в глазах мирового сообщества, является одним из главных препятствий на пути выгодных для нее зарубежных инвестиций. Честный и социально ориентированный бизнес вытесняется с рынка, поскольку коррупция превращает такой бизнес в нерентабельный.

Коррупция имеет высочайшую способность приспосабливаться, непрерывно мимикрирует, видоизменяется и совершенствуется, профессионально использует недостатки и пробелы социально-правового контроля и юридической ответственности.

Правоохранительные органы, сами отчасти пораженные коррупцией, не имеют достаточных возможностей и необходимой реальной независимости для борьбы с институциональной коррупцией. Конгломерат «коррумпированная бюрократия криминальный бизнес - организованная преступность», получивший название «железный треугольник», живет по своим законам.

Коррупция выходит за рамки национальных границ, и борьба с нею требует глобального подхода. Доходы от нее после «отмывания» включаются в мировые и национальные финансовые потоки, подрывая государственные и международные институты власти и экономики. Она угрожает верховенству закона, демократии и правам человека, подрывает моральные устои общества, доверие к власти, принципы государственного управления, равенства и социальной справедливости, препятствует конкуренции, затрудняет экономическое развитие. 
Особенно опасна коррупция в органах государственной власти. В этом случае она представляет собой симбиоз монополии власти, дискреционных полномочий государственных служащих в принятии решений и отсутствия жесткой правовой подотчетности и подконтрольности чиновников. Как показывает практика, коррупция разрушает всю систему государственного управления, способствует падению авторитета государственной власти и престижа государственной службы. Коррупция препятствует развитию экономики и способствует росту организованной преступности, особенно в сфере экономики.

Использование государственной машины организованной преступностью связано преимущественно с коррупцией как способом превращения государственных полномочий в частную собственность. Гегель писал: «Та доля государственной власти, которую приобрел для себя отдельный индивидуум, потеряна для власти всеобщего». Мало того, опираясь на приобретенную часть власти, соответствующие индивиды и криминальные формирования ведут наступление на государство, институты гражданского общества, его ценности. Не решив проблему коррупции, невозможно эффективно решать задачи государственного управления.

Применительно к пониманию феномена коррупции существуют разнообразные методологические подходы. Ее издревле рассматривали в нескольких аспектах социальном, политическом, криминологическом, правовом.

Так, Платон и Аристотель относили коррупцию к политическим категориям. Н. Макиавелли считал ее свидетельством общего заболевания государства, разрушающего гражданскую добродетель. Ш. Монтескье характеризовал ее как дисфункциональный процесс, в результате которого хороший политический порядок или система превращаются в негодные .

В современной научной, учебной и общественно-публицистической литературе также предлагаются различные определения коррупции. Выработка единого понятия о коррупции как основы для определения универсального способа борьбы с ней сложный эволюционный процесс. Интегральный характер коррупции не позволил на сегодняшний день разработать однозначное определение этого сложного явления.

Тем не менее, исторически первые определения коррупции относятся к области права.

Понятие «коррупция» происходит от латинского слова «corruptio», переводимого на русский язык как «порча», «подкуп». В юридической энциклопедии термин «коррупция» определяется как «преступная деятельность в сфере политики или государственного управления, заключающаяся в использовании должностными лицами доверенных им прав и властных возможностей в целях личного обогащения» . Аналогичное определение коррупции дается в большом юридическом словаре .

В уголовно-правовой науке и в правоприменительной практике существуют два основных подхода к определению коррупции. Значительная часть специалистов считает, что коррупция - это присущая любому обществу система подкупа служащих государственного аппарата (должностных лиц), связанная с совершением данными лицами деяний в целях удовлетворения интересов лиц, представляющих незаконное вознаграждение материального характера или иные личные выгоды . Другие видят в коррупции использование государственными служащими своего служебного положения для получения не предусмотренных законом преимуществ в виде имущественных услуг, льгот или иных преимуществ, причем подкуп выступает в данном случае лишь как часть негативного явления.

Источники международного права дают более широкое определение коррупции и, соответственно, расширенный круг субъектов правонарушений, связанных с коррупцией.

Одной из наиболее лаконичных, но информативно содержательных дефиниций является формулировка, предложенная Девятым конгрессом ООН, определяющая 
коррупцию как «злоупотребление государственной властью для получения выгоды в личных целях».

Более развернутое определение разработано в 1995 г. междисциплинарной группой Совета Европы по коррупции: «коррупция представляет собой взяточничество и любое другое поведение лиц, которым поручено выполнение определенных обязанностей в государственном или частном секторе, которое ведет к нарушению обязанностей, возложенных по статусу государственного должностного лица, частного сотрудника, независимого агента или иного рода отношений и имеет целью получение любых незаконных выгод для себя и других». Это определение более полно раскрывает суть данного явления. Во-первых, в категорию субъектов коррупции помимо государственных должностных лиц или лиц, которым поручено исполнение их обязанностей, включены сотрудники частного сектора. Во-вторых, целью коррупции, наряду с личным получением выгод, называется приобретение выгод в интересах других.

Несомненно, это свидетельствует о том, что международное сообщество не сужает понимание коррупции до продажности и подкупа должностных лиц государственного и частного сектора, т. к. она выходит за рамки «сделки» между подкупающей и подкупаемой сторонами. Коррупция в этом понимании может включать в себя должностные хищения, а также иные формы неправомерного использования своих полномочий, статуса и вытекающих из него возможностей в целях извлечения для себя и других различных выгод, льгот, преимуществ.

Конвенция ООН «Против транснациональной организованной преступности» также предлагает меры по криминализации коррупционных преступлений. Согласно ст. 8 Конвенции, уголовно наказуемыми могут быть подкуп, продажность национальных и иностранных публичных должностных лиц или международных гражданских служащих в интересах этих или иных физических и юридических лиц, а также соучастие в этих преступлениях. Рассматриваемая Конвенция в отличие от Страсбургской (1999 г.) не устанавливает специально ответственность за приготовление публичных должностных лиц к вымогательству или принятию какого-либо неправомерного преимущества, а также не требует обязательного распространения указанных деяний на частный сектор. Определение содержания публичного должностного лица она оставляет на усмотрение государств-участников, одновременно передавая им право признания в качестве уголовно наказуемых других форм коррупции .

В Кодексе поведения должностных лиц по поддержанию правопорядка, принятом Генеральной Асамблеей ООН, отмечается, что «понятие коррупции должно определяться национальным правом и охватывать совершение или несовершение какого-либо действия при исполнении обязанностей или по причине этих обязанностей в результате требуемых или принятых подарков, обещаний или стимулов, или их незаконное получение всякий раз, когда имеет место такое действие или бездействие».

По мнению немецких исследователей, с правовой точки зрения это явление не что иное как «дело без пострадавших». Если же говорить о подкупе, то без него немыслимо предпринимательство, ибо он является неотъемлемой частью коммерческой деятельности - в современном индустриальном обществе главной целью стало достижение успеха (результата). Ряд английских специалистов отмечает, что коррупция представляет собой одну из форм организационной аномалии в государственном секторе, которая в зависимости от сферы деятельности имеет свою специфику. Учеными США коррупция определяется как уклонение политических деятелей, сотрудников госаппарата, бизнесменов и других лиц от выполнения ими своих официальных обязанностей и государственных функций ради личных, семейных или групповых интересов с целью обогащения и повышения своего социального статуса.

В юридическом словаре Генри Блэка коррупция понимается как: «деяние, совершаемое с намерением предоставить некое преимущество, несовместимое с 
официальными обязанностями должностного лица и правами других лиц; деяние должностного лица, которое незаконно и неправомерно использует свое положение или статус для извлечения какого-либо преимущества для себя или другого лица в целях, противоположных обязанностям и правам других лиц» .

Например, перуанская делегация предложила понимать под коррупцией подкуп, продажность должностных лиц и использование ими своего влияния для этих целей, а также воздействие со стороны таких лиц на частных лиц в целях выполнения теми «неправомерных или незаконных деяний» (например, подкуп избирателей и т. д.).

Представители Филиппин предложили рассматривать коррупцию как продажность и подкуп публичных должностных лиц, а также соучастие в этом в любой форме, в том числе в целях сохранения или получения власти (политическая коррупция).

Иной подход продемонстрирован пакистанской стороной, где коррупция - более широкое понятие и включает в себя обогащение публичных должностных лиц или близких к ним узких групп за счет использования вверенных им государственных средств, своих служебного положения и имеющегося статуса в связи с занимаемой должностью, взяток и любых других коррупционных действий .

Более объемное определение, значительно расширившее понятие субъекта коррупционных деяний, разработано Междисциплинарной группой по коррупции Совета Европы, которая исследуемый феномен рассматривает не только как взяточничество, но и как «любое другое поведение лиц, которым поручено выполнение определенных обязанностей в государственном или частном секторе и которое ведет к нарушению обязанностей, возложенных на них по статусу государственного должностного лица, частного сотрудника, независимого агента или иного вида отношений и имеет целью получение любых незаконных выгод для себя и других». Подобная новация вызвана стремительным развитием транснациональной коррупции, в структуре которой и покупаемыми и покупателями нередко выступают представители коммерческих и иных негосударственных структур.

В Руководстве по борьбе с коррупцией, подготовленном Секретариатом $\mathrm{OOH}$, коррупция трактуется как совокупность трех классификационных групп криминальных деяний:

а) кража, хищение и присвоение государственной собственности должностными лицами;

б) злоупотребление служебным положением для получения неоправданных личных выгод;

в) конфликт интересов между общественным долгом и личной корыстью.

В тоже время в справочном документе $\mathrm{OOH}$ о международной борьбе с коррупцией указывается, что «коррупция - это злоупотребление государственной властью для получения выгод в личных целях» .

Аналогичное определение коррупции содержится в отчете Всемирного банка, посвященном роли государства в современном мире, где «коррупция - это злоупотребление государственной властью ради личной выгоды» .

Не меньшее количество попыток дать законодательное определение коррупции и связанных с нею терминов предпринималось в Казахстане. По мнению А. А. Чернякова, задача правовой науки состоит в том, чтобы на основе теоретических разработок предложить законодателю нормативную модель определения коррупции. По его мнению, если реально существует фактическая коррупция, то она должна быть перенесена на юридическую модель и получить нормативное определение в виде конкретной нормы уголовного закона. В этой норме должны быть отражены обязательные элементы состава преступления, именуемого коррупцией . 
По мнению А. Н. Агыбаева, «коррупция представляет собой ... любое ... преступление должностных лиц, совершенные с целью получения любых незаконных выгод для себя и других» .

По мнению Н. Ф. Кузнецовой, коррупция охватывает три поведенческие подсистемы - криминальное, правонарушительное и аморальное поведение. Криминальное поведение охватывает два вида терминологически и содержательно различающихся подкупов (взяточничество и подкуп) .

В соответствии со ст. 2 Закона РК «О борьбе с коррупцией» от 2 июля 1998 г., под коррупцией понимается: «Не предусмотренное законом принятие лично или через посредников имущественных благ и преимуществ лицами, выполняющими государственные функции, а также лицами, приравненными к ним, с использованием своих должностных полномочий и связанных с ними возможностей, а равно подкуп данных лиц путем противоправного предоставления им физическими и юридическими лицами указанных благ и преимуществ» .

Многообразие точек зрения на определение коррупции свидетельствует о сложности этого явления и требует более глубокого и всестороннего его изучения. Вопервых, углубления теоретического уровня познания коррупции (формирования четкого правового определения, исследования причин возникновения коррупции и факторов, способствующих ее развитию). Во- вторых, изучения влияния коррупции на экономическую, социальную и политическую жизнь общества и формирования системы практических мер по борьбе с этим явлением.

Анализ вышеперечисленного позволяет нам сделать вывод о том, что коррупции как явлению присущи определенные признаки, и оно представляет, прежде всего, социальное явление, не имеющее точного юридического определения, и как всякое явление оно имеет большой потенциал к своему развитию. Другим отличительным признаком коррупции является определенный круг субъектов, которые могут являться субъектами коррупционных правонарушений: государственные служащие, представители власти, лица, выполняющие организационно-распорядительные или административнохозяйственные функции в государственных органах, вооруженных силах, а также лица, выполняющие управленческие функции в коммерческой или иной организации. Особым признаком коррупции является то, что она совершается путем использования указанными субъектами своего служебного положения, правового статуса и авторитета занимаемой должности вопреки интересам службы и установленным нормам права и морали. Данные действия направлены непосредственно на получение имущественной или иной выгоды и на удовлетворение тех или иных потребностей и интересов.

На основе проведенного исследования приходим к выводу, что определение понятия коррупции, как социально-правового явления, не может служить точным ориентиром для правоприменительной практики, поскольку, с одной стороны, оно не раскрывает всего многообразия конкретных форм коррумпированного поведения, требующего специальной правовой оценки, а с другой, - предоставляет широкие возможности для привлечения к ответственности практически за любое нарушение служебной дисциплины.

$$
* * *
$$

1. Курбатов Е. В. Получение взятки: уголовно-правовые, процессуальные и криминалистические аспекты / Учеб. пособ. / под ред. И. Ш. Борчашвили - Караганда, 2001.

2. Каминский М. К. Расследование взяточничества. - М., 1999.

3. Хилобок М. П. Расследование должностных преступлений. — М., 1976.

4. Нукенов М. О. Коррупционные преступления. Криминологический и уголовно-правовой анализ. Алматы, 1999.

5. Шиканов В.И. Теория тактических операций следователя (перспективы развития)//Алгоритм и организация решений следственных задач. Иркутск, 1987.

6. Манахов С.А. Расследование преступлений о коррупции // Закон и право. 2004. - № 9. 


\title{
Палий А.Ю. \\ Научно-теоретический анализ противоречий о целях деятельности организованных преступных сообществ, содержащихся в действующем уголовном законодательстве, и пути их преодоления: по материалам Республики Крым
}

\author{
Судья Верховного Суда Республики Крым
}

(Россия)

doi: $10.18411 / \mathrm{sr}-10-08-2017-11$

idsp: 000001:sr-10-08-2017-11

Все чаще на международном законодательном уровне находят свое отражение упоминания о необходимости противодействия различным формам организованной преступности, ввиду того, что данное преступное явление признается одной из основных угроз полноценного функционирования и развития современного общества. Соответственно, вышесказанное позволяет утверждать, чтосовременная организованная преступность, представляя собой достаточно серьёзную угрозу для общества, позволяет поставить её в один ряд с угрозами национальной безопасности России. В связи с расширением масштабов организованной преступности и усилением степени общественной опасности, исходящей от данной формы преступного явления, в Уголовный кодекс Российской Федерации за последние несколько лет были внесены соответствующие изменения и дополнения как в Общую, так и в Особенную его части.

Неоднократно в научной литературе предлагалось внести изменения в Уголовный кодекс РФ, дополнив его статьей, содержащей понятие организованной преступной деятельности. В проекте закона «О борьбе с организованной преступностью» содержалась дефиниция преступной деятельности как «системы деяний с заранее обдуманным умыслом по приготовлению, покушению, совершению одного или более преступлений, предусмотренных статьями Особенной части Уголовного кодекса РСФСР или настоящим Федеральным законом, а также по легализации и приумножению преступных доходов, созданию иных благоприятных условий для совершения преступлений». Разными группами разработчиков аналогичные предложения по принятию Федерального закона «О борьбе с организованной преступностью» вносились на рассмотрение в Государственную Думу РФ в 1995, 1997, 2006 годах, но по разным причинам данные проекты так и не вступили в законную силу.

При этом, необходимость разработки и принятия данного нормативного правового акта в настоящее время подтверждается потребностями теории и практики противодействия преступлениям, совершаемым организованными преступными сообществами. Так, 74 \% из числа опрошенных сотрудников правоохранительных органов считают необходимым условием повышения эффективности деятельности по расследованию и раскрытию преступлений, совершенных организованными преступными сообществами на территории Республики Крым, разработку и принятие на федеральном уровне единого нормативного правового акта, регламентирующего вопросы противодействия организованной преступности в Российской Федерации (на примере Федерального закона «О противодействии терроризму», Федерального закона «О противодействии экстремистской деятельности»). Кроме того, $39 \%$ респондентов высказались в пользу необходимости дополнения статьи 35 Уголовного кодекса РФ понятием организованной преступности с указанием целей совершения данных преступлений.

Это объясняется тем, что одной из криминалистически значимых проблем, возникающих в ходе расследования рассматриваемой категории преступлений, по мнению практических работников (отметили 68\% участников опроса), является установление целей и мотивов совершения преступлений организованными преступными 
сообществами на территории Республики Крым в качестве обстоятельств, подлежащих доказыванию. При этом анализ изучения материалов уголовных дел данной категории, рассмотренных судами Республики Крым в период с апреля 2014 по июль 2017 года, свидетельствует о том, что в $96 \%$ случаев в материалах уголовных дел содержались подтвержденные сведения об установлении целей преступной деятельности организованных преступных сообществ.

В данном случае наглядно проявляется существенное противоречие, допущенное законодателем при формулировании диспозиции статьи 210 Уголовного кодекса РФ, в части несогласованности отраженных в ней целей создания (руководства, координации и т.д.): «Создание преступного сообщества (преступной организации) в целях совместного совершения одного или нескольких тяжких или особо тяжких преступлений...». При этом статья 35 Общей части Уголовного кодекса РФ в качестве целей преступной деятельности преступных сообществ указывает на то, что «...члены которых объединены в целях совместного совершения одного или нескольких тяжких либо особо тяжких преступлений для получения прямо или косвенно финансовой или иной материальной выгоды». В связи с чем следует согласиться с мнением Н.Ф. Кузнецовой и И.М. Тяжковой: «Данный признак не является безупречным, хотя бы уже в силу того, что определять качество преступного образования через тяжесть совершенного его участниками преступления некорректно, поскольку по данному признаку формирование не может быть квалифицировано как преступное сообщество. Группа лиц по предварительному сговору и организованная группа также могут создаваться для совершения тяжких и особо тяжких преступлений, ибо никаких запретов по этому поводу закон не содержит. Следовательно, создается возможность либо неоправданного сужения понятия организованной группы, либо, наоборот, необоснованной оценки случаев совершения организованной группой тяжких или особо тяжких преступлений как выполненных преступным сообществом».

Важно отметить, что включая в 2013 г. в Уголовный кодекс РФ статьи 205.4 («Организация террористического сообщества и участие в нем») и 205.5 («Организация деятельности террористической организации и участие в деятельности такой организации»), законодатель не учел уже существующее положение ст. 35, которое содержит указание на цель преступного сообщества (преступной организации) получение прямо или косвенно финансовой или иной материальной выгоды.Данная норма, безусловно, не соотносится с целью преступлений, предусмотренных в ст. 205.4 и 205.5 Уголовного кодекса РФ, поскольку террористические сообщества (организации) не обязательно и не всегда преследуют материальную или финансовую выгоду, что является особо важным обстоятельством, подлежащим доказыванию, с криминалистической и процессуальной точек зрения.

При этом важно отметить, что Постановление Пленума Верховного Суда РФ от 10 июня 2010 г. № $12 « 0$ судебной практике рассмотрения уголовных дел об организации преступного сообщества (преступной организации) или участии в нем (ней)» разъясняет, что «...что организованная преступность в ее различных проявлениях посягает на общественную безопасность, жизнь и здоровье граждан, собственность, нарушает нормальное функционирование государственных, коммерческих и иных организаций и общественных объединений».

Ярким примером совершения преступлений организованными преступными сообществами без преследования целей извлечения материальной выгоды являются преступления террористической, экстремистской направленности, совершенные исключительно в целях устрашения населения, дестабилизации функционирования органов государственного управления, разжигания вооруженных конфликтов, преследования религиозных целей и пр. Соответственно, положения как Общей, так и Особенной частей Уголовного кодекса РФ, отражающих особенности совершения 
преступлений организованными преступными сообществами, находятся в противоречии друг с другом и с объективной реальностью.

В связи с тем, что в настоящее время в юридической науке существует многообразие подходов к теоретическому определению организованной преступности, но отсутствует нормативное закрепление данного определения, представляется целесообразным дополнить часть 4 статьи 35 Уголовного кодекса РФ определением следующего содержания: «Преступление признается совершенным преступным сообществом (преступной организацией), если оно совершено структурированной организованной группой или объединением организованных групп, действующих под единым руководством, члены которых объединены в целях совместного совершения одного или нескольких тяжких либо особо тяжких преступлений для получения прямо или косвенно финансовой или иной материальной выгоды, а равно в целях посягательств на общественную безопасность и общественный порядок, жизнь и здоровье граждан, основы государственной власти, мир и безопасность человечества».

Анализ действующих нормативных правовых актов на федеральном и международном уровнях убедительно доказал, что в настоящее время при всем разнообразии определений организованной преступности отсутствует нормативное закрепление данного понятия. Так, Конвенция против транснациональной организованной преступности, а так же три протокола, принятые в дополнение к ней, при всем многообразии применяемых понятий, не содержат определения организованной преступности.

С учетом выявленных ранее учеными-правоведами особенностей организованной преступности в целом, и преступлений, совершаемых организованными преступными сообществами в частности (в том числе, на территории Республики Крым), целесообразно нормативно определить и закрепить в проекте Федерального закона «О противодействии организованной преступности» понятие организованной преступности в следующей редакции: «Организованная преступность - это системно связанная совокупность преступлений, совершаемых участниками устойчивых, иерархизированных, планомерно действующих преступных структур, деятельность которых согласуется, будучи направлена на извлечение максимальной прибыли из преступного бизнеса, на определенной территории или в определенной сфере, взятой под контроль в целях получения прямо или косвенно финансовой или иной материальной выгоды, а равно в целях посягательств на общественную безопасность и общественный порядок, жизнь и здоровье граждан, основы государственной власти, мир и безопасность человечества».

Часть 5 статьи 35 Уголовного кодекса РФ говорит о том, что лицо, создавшее организованную группу или преступное сообщество (преступную организацию) либо руководившее ими, подлежит уголовной ответственности за их организацию и руководство ими в случаях, предусмотренных статьями 205.4, 208, 209, 210 и 282.1 Кодекса, а также за все совершенные организованной группой или преступным сообществом (преступной организацией) преступления, если они охватывались его умыслом. Аналогичная формулировка относится и к иным участникам преступного сообщества. Результаты проведенного анализа и обобщения оперативной, следственной и судебной практики по рассматриваемой категории дел наглядно свидетельствует о том, что перечисленные законодателем в ч.5 статьи 35 статьи Особенной части кодекса в полной мере не отражают конкретные формы преступной деятельность организованных преступных сообществ, поскольку преступными сообществами совершаются и иные преступления, совершение которых возможно в данной организованной преступной форме, в том числе исходя из целей создания и деятельности конкретного преступного сообщества. В связи с чем представляется, что перечисление в ч. 5 статьи 35 Уголовного кодекса РФ конкретных составов преступлений, предусмотренных Особенной частью 
Уголовного кодекса, излишне ввиду многообразия целей деятельности организованных преступных сообществ и форм осуществления их деятельности.

Одним из наиболее важных направлений повышения эффективности противодействия организованным формам преступной деятельности является их правильное и четкое отграничение. В настоящее время Уголовный кодекс РФ, наряду со ст. 210, содержит семь статей, предусматривающих ответственность за деятельность различных конкретных разновидностей организованных групп (ст. 205.4, 205.5, 208, 209, $239,282.1,282.2)$, что актуализирует на практике вопрос об их конкуренции друг с другом. Говоря о соотношении организации преступного сообщества (преступной организации) или участия в нем (ней) со смежными составами преступлений, следует акцентировать внимание на выявлении их общих и отличительных криминалистически значимых признаков.

При этом, при рассмотрении наиболее общей по отношению к иным составам статья 210 Уголовного кодекса РФ «Организация преступного сообщества (преступной организации) или участие в нем (ней)» в сравнении со статьей 208 «Организация незаконного вооруженного формирования или участие в нем», можно заключить, что преступление, предусмотренное статье 210 отличается прежде всего направленностью деятельности (совершение тяжких или особо тяжких преступлений), а также возможным отсутствием оружия у членов преступного сообщества. От бандитизма анализируемое преступление отличается отсутствием обязательной цели нападения на граждан или организации, а также возможным отсутствием оружия. На основании результатов изучения уголовных дел достоверно известно, что преступное сообщество нередко создается для занятия контрабандой, торговлей наркотиками, фальшивомонетничеством, хищением чужого имущества в крупных размерах и т.п.

Кроме того, в статье 208 УК РФ говорится о таком вооруженном формировании, которое не предусмотрено федеральным законом. В ст. 1 Федерального закона от 31 мая 1996 г. № 61-Ф3 «Об обороне» сказано, что запрещаются и преследуются по закону создание и существование формирований, имеющих военную организацию или вооружение и военную технику либо в которых предусматривается прохождение военной службы, не предусмотренных федеральными законами.Таким образом, отличительным признаком незаконного вооруженного формирования является, прежде всего, то, что оно представляет собой разновидность военного формирования и совершается с целью осуществления задач военного характера. Эти цели могут быть и общественно полезны в представлении какой-то определенной группы лиц, они могут создаваться с целью защиты населения от возможных боевых или иных провокационных проявлений экстремистски настроенных групп, но главная их противозаконность заключается в том, что они созданы вопреки положениям Закона «Об обороне».

В основу разграничения двух анализируемых преступлений с криминалистической и процессуальной точек зрения должна быть положена прежде всего цель их создания. Преступное сообщество (преступная организация) всегда создается с противоправной целью для совершения тяжких и особо тяжких преступлений для получения прямо или косвенно финансовой или иной материальной выгоды. Организация незаконного вооруженного формирования преследует иные цели: политические, социально-бытовые (например: защитить город или населенный пункт от криминальных посягательств), националистические и др.

Одним из наиболее важных на протяжении многих лет остается соотношение преступлений, предусмотренных ст. 210 и ст. 209 (бандитизм) Уголовного кодекса РФ. Традиционно банда считается самой опасной разновидностью организованной группы, хотя некоторые ученые относят ее к числу преступных сообществ. По мнению С.В. Расторопова, нацеленность на совершение нападений на граждан или организации отличает бандитизм от преступлений, предусмотренных ст. 208 и 210 УК РФ. Банда - это 
всегда вооруженная устойчивая группа, в то время как преступное сообщество может не иметь ни одной единицы оружия, т.к. может создаваться для совершения таких преступлений, которые не требуют для их совершения применения оружия, например при совершении экономических преступлений.

Трудности при разграничении со ст. 210 вызывает и ст. 239 УК РФ (создание некоммерческой организации, посягающей на личность и права граждан). Применительно к ней можно заметить, что объективно данное преступление выражается в создании религиозного или общественного объединения, нередко во внешне законных формах. Соответственно, основные цели такого объединения преимущественно религиозные или общественные, но не откровенно преступные. Преступный характер таким объединениям придают насильственные и иные противоправные способы воздействия на их членов. Напротив, преступное сообщество не стремится к легализации своей деятельности (хотя это и не исключается), и его основные цели - совершение тяжких или особо тяжких преступлений для получения прямо или косвенно финансовой или иной материальной выгоды.

В данном случае, применительно к Республике Крым следует согласиться с мнением автора процессуально-публицистического издания о том, что «...За считанные годы бандитизм в Крыму развился, структурализовался, неразрывно сросся с бизнесом, пробился в политику, стал почти вровень с легитимной властью, частично переродился в «нормальный» бизнес и нормальную политику. Он явил образцы крайнего беспредела и глубокого «черного» порядка ... Пройдя все основные ступени и, наверное, впервые посерьезному, не слишком маскируясь (например, в национально-освободительные, националистические или религиозные одежды), крымский бандитизм бросил вызов всякой прочей власти».

Другим не менее важным вопросом является соотношение целей преступлений, предусмотренных ст. 210 и ст. 282.1 («Организация экстремистского сообщества»), ст. 282.2 («Организация деятельности экстремистской организации») УК РФ. Экстремистское сообщество (ст. 282.1 УК РФ), несмотря на свое название, также является типичной разновидностью организованной группы. Как верно указывает И.В. Сироткин, «терминологически экстремистское сообщество представляет собой разновидность преступного сообщества, предусмотренного ч. 4 ст. 35 УК РФ. Однако при изучении его определения в ст. 282.1 УК РФ можно установить, что оно таковым не является ввиду отсутствия признака сплоченности... В то же время в ч. 1 ст. 282.1 содержится указание на структурный характер экстремистского сообщества, а также сформулированное по аналогии со ст. 210 УК РФ положение об ответственности за создание объединения организаторов, руководителей или иных представителей частей или структурных подразделений такого сообщества в целях разработки планов и (или) условий для совершения преступлений экстремистской направленности. Подобная формулировка ст. 282.1 УК РФ приводит к абсолютному смешению понятий организованной группы и преступной организации».

Схожа ст. 210 УК РФ и с экстремистской организацией, о которой говорится в ст. 282.2 УК РФ. Она представляет собой общественное или религиозное объединение или иную организацию. Экстремистский характер придает этой организации наличие вступившего в законную силу решения о ликвидации или запрете деятельности в связи с осуществлением экстремистской деятельности. Для преступного сообщества не имеет большого значения его легальная регистрация в каких-либо организационно-правовых формах.

Проведенное научно-теоретическое исследование позволило выявить как общие, так и отличительные целевые признаки, присущие преступлениям, предусмотренным ст. $210,205.4,205.5,208,209,239,282.1$ и 282.2 Уголовного кодекса РФ и наглядно подтвердить, что помимо указанных в части 4 статьи 35 УК РФ целей совместного 
совершения одного или нескольких тяжких либо особо тяжких преступлений для получения прямо или косвенно финансовой или иной материальной выгоды, преступные сообщества на территории Республики Крым совершают преступления в целях посягательств на общественную безопасность и общественный порядок, жизнь и здоровье граждан, основы государственной власти, мир и безопасность человечества. Данное обстоятельство подтверждает ранее сделанный вывод о необходимости дополнения части 4 статьи 35 Уголовного кодекса РФ в части формулирования целей создания организованного преступного сообщества.

$$
* * *
$$

1. Кузнецова Н.Ф., Тяжкова И.М, Курс уголовного права. Т. 1 Преступление. Электронный ресурс // Режим доступа: http://www.studfiles.ru/preview/5834340/page:27. Дата обращения 01.06.2017.

2. Куфлева В.Н. Вопросы разграничения организации преступного сообщества (преступной организации) или участия в нем (ней) со смежными составами преступлений // Общество и право, 2015. № 1 (51). С. 89. (c 89-93)

3. Сироткин И. В. О совершенствовании уголовно-правовых норм об ответственности за создание, руководство и участие в организованных группах и преступных организациях // Вестн. Томск.гос. унта. 2008. Вып. 314. С. 127.

4. Суд присяжных: квалификация преступлений и процедура рассмотрения дел: научно-практическое пособие / Под.ред. А. В. Галаховой. М., 2006. С. 64.

5. Хижняк Д.С. О проекте стратегии противодействия транснациональной криминальной деятельности в Российской Федерации // Библиотека криминалиста. Научный журнал. 2016. № 6 (29). С. 17-30.

6. Чернецов К.Т. Крым бандитский. География - соучастница преступности. Часть 1. // Электронный pecypc: http://www.e-reading.club/chapter.php/29172/1/Chernecov_-_Krym_banditskiii.html. Дата обращения 18.05.2017.

\section{Пучкова В.В. \\ Конституционная обязанность граждан о соблюдении законодательства в сфере здравоохранения \\ Смоленский филиал Международного юридического института}

(Россия, Смоленск)

doi: $10.18411 / \mathrm{sr}-10-08-2017-12$

idsp: 000001:sr-10-08-2017-12

\section{Аннотация}

Актуальность темы обусловлена тем вниманием, которое в настоящее время руководством страны обращается на реализацию основополагающих конституционных прав граждан России, связанных с охраной здоровья. Цель статьи - проанализировать проблемы реализации статьи 27 Ф3 «Об основах охраны здоровья граждан». В статье анализируется конституционная обязанность граждан о соблюдении законодательства в сфере здравоохранения.

Ключевые слова: право на охрану здоровья; медицинская помощь; медицинские осмотры; обязанность о соблюдении законодательства; здравоохранение

\section{Annotation}

The relevance of the topic is due to the attention that the country's leadership is now turning to the implementation of the fundamental constitutional rights of Russian citizens related to health protection. The purpose of the article is to analyze the problems of implementation of Article 27 of the Federal Law "On the Fundamentals of Citizens' Health Protection". The article analyzes the constitutional duty of citizens to observe the legislation in the field of health care.

Key words: right to health protection; health care; Medical examinations; Obligation to comply with legislation; Health care 
Статьей 27 Федерального закона «Об основах охраны здоровья граждан в РФ» установлена обязанность о соблюдении законодательства в сфере здравоохранения, установлено, что каждый человек должен бережно относиться к своему здоровью, здоровью детей и окружающих лиц. Также граждане должны заботиться о своем здоровье и здоровье своих детей, приучать их к здоровому образу жизни. Должны проходить обязательные медицинские осмотры. Те граждане, которые страдают заболеваниями, представляющими опасность для окружающих, обязаны проходить обследование, лечение и заниматься профилактикой своих заболеваний. Лица, которые находятся на лечении, обязаны соблюдать режим и выполнять назначение медицинских работников. Эта норма закона свидетельствует о том, что нарушителями могут оказаться каждый гражданин, не соблюдающий режим лечения и предписания врача. В связи с этим к любому человеку можно применить данную норму закона. Только каким образом эта норму будет реализовываться, закон пояснений не дает.

В соответствии с Конституцией РФ медицинская помощь является добровольной. Это значит, что каждый человек вправе обратиться за медицинской помощью в лечебные учреждения. Это, прежде всего, право каждого гражданина, а не обязанность. Никто не может привлекаться к обязательным медицинским осмотром, за исключением граждан, которые в соответствии со своей профессией обязаны проходить такие осмотры ежегодно. Перечень этих профессий утверждаются постановлением Правительства РФ.

Таким образом, мы наблюдаем противоречие между нормами Конституции РФ и нормами нового закона, которое заключается в обязанности каждого гражданина заботиться о своем здоровье, проходить обязательные медицинские осмотры. Следовательно, в данную норму следует внести изменения, в частности исключить обязательное прохождение медицинских осмотров без исключения для всех граждан и включить разъяснение относительно граждан определенного круга профессий. Также в данном федеральном законе следует указать, что медицинская помощь является добровольной, так как каждый гражданин вправе решать выполнятьему рекомендации врача или отказаться от лечения. Это право каждого гражданина. А норма, обязывающая выполнять назначения медицинских работников полностью, противоречит действующей Конституции РФ и лишает нас право на отказ от медицинского вмешательства.

Что касается болезней, опасных для окружающих, которые подлежат обязательному лечению. То здесь закон умалчивает, какие болезни следует признать опасными. В настоящее время и грипп является смертельно опасным заболеванием, только вот распознать его бывает сложно, так как некоторые симптомы очень похожи на простую простуду. В связи с этим следует более четко регламентировать перечень опасных болезней для окружающих.

Особой защите в сфере охраны здоровья подлежат дети. Это подтверждается нормой, регламентирующей защиту прав ребенка при несоблюдении их законными представителями обязанностей по реализации прав детей на оказание медицинской помощи. Следует отметить, что данная норма требует доработки, пояснений, что является неисполнением родителями или иными законными представителями своих обязанностей по защите прав ребенка на охрану здоровья. Потому что на практике встречаются случаи обращений медицинских работников в органы опеки и попечительства в связи с отказом родителей от вакцинации своих детей. Однако данное право принадлежит исключительно родителям детей и их следует убедить в необходимости проведения прививки. Кроме того, на практике встречаются случаи, когда родители отказываются от проведения лечения, от хирургического вмешательства или иных видов медицинских вмешательств. В данных случаях, с одной стороны, можно усмотреть неисполнение родителями своих 
обязанностей по реализации прав ребенка по охране здоровья и медицинскую помощь, с другой стороны, это их право отказаться от лечения и медицинского вмешательства. Поэтому данная норма требует доработки. А именно, следует указать, что отказ родителей от медицинского вмешательства относительно их детей нельзя рассматривать как неисполнение родителями своих обязанностей по реализации прав детей на охрану здоровья и медицинскую помощь. Следовательно, данная норма должна быть конкретизирована, путем внесения дополнений относительно перечисления случаев, при которых родители не исполняют своих обязанностей в области охраны здоровья.

Что касается, возникновения опасности, относительно жизни ребенка в случае отказа родителей от медицинского вмешательства, процедура оказания медицинской помощи четко регламентирована в Федеральном законе «Об основах охраны здоровья граждан в РФ», то есть решение о медицинском вмешательстве принимает либо консилиум врачей, либо суд.

Правовое регулирование права на охрану здоровья детей является первоочередной задачей государства. С целью охраны здоровья детей на законодательном уровне установлены права на диспансерное наблюдение и лечение в детских и подростковых медицинских учреждениях, медико-социальную помощь и питание на льготных условиях за счет средств бюджетов всех уровней, на санаторно-гигиеническое образование. Кроме того, дети имеют право на обучение и труд в условиях, отвечающих требованиям гигиены и безопасности с целью предотвращения вредных факторов на состояние здоровья, а также отвечающих их физиологическим особенностям и состоянию здоровья. Данные условия должны создаваться с целью сохранения и укрепления здоровья детей. Дети имеют право на получение бесплатной медицинской помощи, на получение бесплатной медицинской консультации за счет средств бюджетов всех уровней. Несовершеннолетние в возрасте 15 лет имеют право на добровольное информированное согласие на медицинское вмешательство или отказ от него. В настоящее время на законодательном уровне установлен приоритет охраны здоровья детей.

В настоящее время разработана программа мероприятий по охране здоровья матери и ребенка. Данная программа нацелена на формирование здорового образа жизни и профилактики заболеваний у детей, создание условий для оказания доступной и качественной медицинской помощи детям и матерям. Кроме того, данная программа направлена на улучшения состояния здоровья детей и матерей, снижение материнской, младенческой и детской смертности. Для реализации перечисленных целей необходимо решить задачи по развитию специализированной медицинской помощи матерям и детям, по обеспечению доступности и повышения качества медицинской реабилитации детей в условиях трехуровневой системы оказания медицинской помощи. Кроме того, необходимо совершенствовать и развивать пренатальную и неонатальную диагностику, неонатальную и фетальною хирургию, решать задачи по снижению уровня впервые установленной инвалидности детей и другие задачи, направленные на реализацию охраны здоровья детей. Программа реализуется в 2013 - 2015 годах[3].

Рассматривая правовое регулирование права граждан на охрану здоровья и медицинскую помощь можно выделить группу граждан особо нуждающихся в охране здоровья и медицинской помощи - пенсионеры. Следует отметить, что проводимая модернизация здравоохранения не доходит до населения, особенно до старшего поколения - пенсионеров, которые наравне с другими гражданами имеют право на охрану здоровья и на медицинскую помощь. Для удовлетворения потребностей пенсионеров в медицинской помощи необходимо осуществлять строительство медицинских организаций, деятельность которых будет направлена на реабилитацию после лечения в 
стационаре и предоставление адресных медицинских услуг, обеспечивающих незамедлительное оказание медицинской помощи в самых трудных ситуациях, в которых оказались пенсионеры.

В 2014 году в Москве пенсионерам из числа инвалидов разных категорий и групп, инвалиды и участники ВОВ, ветераны боевых действий, взамен натуральных льгот получили ежемесячную денежную выплату. Если указанные граждане отказываются от начисления денежных выплат, пользуются «социальным пакетом». В «социальный пакет» входят:

- приобретение лекарственных средств на льготных основаниях - 646,71 рублей;

- санаторная путевка - 100,05 рублей;

- $\quad$ проезд к месту санаторного лечения - 92,89 рублей.

- В сумме пакет составляет 839, 65 рублей [4].

В 2017 году на государственном уровне как таковых льгот для пенсионеров не предусмотрено. Однако местные органы самоуправления наделены правом принимать свои законодательные нормы по предоставлению гражданам пенсионного возраста какихлибо региональных видов социальной помощи. Законодатель на уровне регионов действует по-разному [5].

Однако в связи с удорожанием жизни, повышением цен не только на продукты питания, но и на транспортные услуги, лекарственные средства, этого недостаточно. Необходимо пересмотреть эту норму и повысить размеры указанных выплат. Кроме того, в связи с низким уровнем обеспечения пенсионеров необходимо льготы в сфере оказания медицинских услуг, обеспечения лекарственными средствами, медицинскими изделиями предусмотреть для всех пенсионеров независимо от их статуса (ветераны боевых действий, инвалиды ВОВ и т.д.). С целью охраны здоровья пенсионеров следует на государственном уровне предусмотреть более детально льготы в сфере охраны здоровья и оказания медицинской помощи.

Таким образом, реализация прав граждан в сфере охраны здоровья должно соответствовать обязанности каждого гражданина заботиться о своем здоровье и о здоровье своих детей. С этой целью необходимо проходить периодические медицинские осмотры и диспансеризацию, потому что каждый человек ответственен за состояние своего здоровья, здоровья своих детей и его поведение должно исключать действия, причиняющие вред своему здоровью. Сама норма не является карательной, так как законодательством не предусмотрены санкции в отношении граждан. Норма об обязанности сохранения своего здоровья направлена, прежде всего, на повышение ответственности за сохранение своего здоровья направлена.

Для действенной реализации конституционного права граждан на охрану здоровья и медицинскую помощь в Российской Федерации органами государственной власти, на региональном уровне, органами местного самоуправления должна проводиться работа по повышению правовой культуры населения в сфере здравоохранения. Кроме того возникает необходимость в информированности населения в области охраны здоровья в соответствии с предоставлением адресной информации.

В связи с установлением на законодательном уровне ответственности граждан за состояние своего здоровья необходимо обеспечить:

- расширение социальной базы в области охраны здоровья путём привлечения к этой деятельности общественные, религиозные организации и граждан; 
- реорганизацию системы санитарно-образовательной работы, обеспечить её массовость, образовать группы самопомощи и взаимопомощи в государственных и муниципальных учреждениях;

- широкое привлечение средств массовой информации к популяризации здорового образа жизни.

$$
* * *
$$

1. Конституция РФ (принята всенародным голосованием 12.12.1993) (с учетом поправок, внесенных Законами РФ о поправках к Конституции РФ от 30.12.2008 N 6-ФКЗ, от 30.12.2008 N 7-ФКЗ) /"Российская газета", N 7, 21.01.2009.

2. Федеральный закон Российской Федерации от 21 ноября 2011 г. N 323-Ф3 "Об основах охраны здоровья граждан в Российской Федерации" / «РГ» - федеральный выпуск № 563923 ноября 2011 г.

3. Приказ Министерства здравоохранения РФ от 28 июня 2013 г. № 420 «Об утверждении программы мероприятий по охране здоровья матери и ребенка» [электронный продукт] / Режим доступа: base.consultant.ru>cons/cgi/online.cgi?req=doc...n / Время актуальности: 28.06.13г.

4. Монетизация льгот инвалидам и пенсионерам в 2014 году / [Электронный продукт] / Режим доступа: progavrichenko.ru>lgoty-posobiya-pensii...lgot.../ Время актуальности: 19.03.2014 г.

5. Монетизация льгот в России в 2017 году /[ Электронный продукт] / Режим доступа: http://progavrichenko.ru/lgoty-posobiya-pensii/monetizaciya-lgot-v-rossii-v-2017-godu.html / Время актуальности: 17.05.17 г. 


\title{
РАЗДЕЛ V. ФИЛОЛОГИЯ
}

\author{
Андреева Е.Г. \\ Олицетворяющая метафора в научном тексте \\ (сопоставление английского и русского языков)
}

Санкт-Петербургский Государственный Университет (Россия, Санкт-Петербург)

doi: $10.18411 / s r-10-08-2017-13$

idsp: 000001:sr-10-08-2017-13

\section{Аннотация}

Статья посвящена сопоставлению олицетворяющей метафоры в английских научных и научно-публицистических текстах и их переводах на русский язык. Соответствия и расхождения между языками рассматриваются с переводческой точки зрения.

Ключевые слова: Метафора, олицетворение, одушевленность, трансформации.

\section{Abstract}

The paper centers around antropomorhic metaphors in specialist texts and journalism in English and their translations into Russian. Similarities and differences between the languages are examined from the point of view of translation techniques.

Keywords: Metaphor, antropomorphism, animateness, transformations.

Метафора, ее функции и употребимость в художественном тексте, как поэтическом, так в прозаическом активно исследовались и продолжают исследоваться на материале разных языков. Когнитивные метафоры, по Дж.Лакоффу (Lakoff, 2003), формируют мышление и мировосприятие носителей разных языков, в определенном смысле детерминируя и соответствующие культуры. Олицетворяющие метафоры можно рассматривать как один из типов когнитивных метафор, когда за счет них неодушевленному объекту приписываются антропоморфические свойства, так что и сам объект начинает восприниматься как живой.

Целью данного сообщения является сопоставительный анализ сочетаний "имя+глагол" в английском языке и их переводов на русский, когда в компонентах такого сочетания можно усмотреть метафорический перенос за счет их семантической несогласованности (неодушевленность имени - одушевленность глагола), и выявление тех случаев, где английский и русский языки различаются с точки зрения способности или неспособности создавать такие сочетания.

То, что английские неодушевленные существительные легко согласуются с глаголами активного действия, отмечается в работах многих современных зарубежных исследователей (Šeškauskienè, 2009, Low, 1999, и др.), и дело здесь не только в "усиленной" метафоризации, свойственной английскому языку, но и в том, что английские глаголы (за редким) исключением являются одновременно переходными, и непереходными, так что переходное (активное) значение в некотором смысле переносится на непереходное (пассивное). Классическим примером может служить I always sell a lot of books и The book sells well, когда существительное во втором предложении воспринимается как активный деятель за счет того, что оно употреблено при глаголе активного действия в действительном залоге. Здесь уместно вспомнить о глубинных падежах (book в обоих примерах является дативом, хотя в терминах традиционного синтаксиса его функции различны - подлежащее и прямое дополнение), поскольку данное различие между английским и русским объясняется также и различиями между 
семантическими ролями подлежащих первого и второго предложений и способностью конкретного глагола конкретного языка сочетаться с ними.

Метафора персонификации относится к разряду онтологических метафор, которые призваны помогать осмыслить события, действия, идеи и эмоции в качестве дискретных чувственно воспринимаемых объектов, облегчать структурирование окружающего мира и создавать более понятную, объяснимую наивную картину мира. Такие метафорические закономерности, как антропоморфизм или зооморфизм, можно считать универсальными, хотя их функциональный вес в разных языках может заметно различаться. Кроме того, в подобных универсальных парадигмах есть свои национально-культурные особенности, например, далеко не во всех языках переносные значения слов «низкий», «черный» являются пейоративными, или же вообще обладают метафорическим значением (ср. черная зависть в русском языке и green-eyed monster в английском, которые приблизительно сопоставимы) (подробнее - см. Юрков, 2012). «Эталонные» основания для создания метафор и метафорических переносов безусловно этно-специфичны, хотя в каких-то ситуациях прослеживаются и сходные тенденции в разных языках. Так, скажем и в русском и в английском языках время летит (time flies), однако в русской культуре человек спит, как убитый, а в английской - как бревно (sleeps like a log).

С другой стороны, если следовать А.Вежбицкой, то в основе рассматриваемого различия между английским и русским языками, лежит то, что является особым языковым типом - агентивным (английский) и пациентивным (русский). Для языков первого типа характерны номинативные и номинативоподобные конструкции, в то время как для языков второго типа - дативные и дативоподобные, не в смысле семантических ролей, а в смысле падежной формы подлежащего (сp. Мау І...? и Можно мне...? (Вежбицкая, 1996: 55). И хотя Вежбицкая говорит в первую очередь об одушевленных подлежащих в языках этих двух типов, можно заметить, что это так же верно и для подлежащих, выраженных неодушевленными существительными. В таком случае английское this year saw объясняется агентивностью одного языка, а соответствующее ему русское в этом году произошло - пациентивностью второго.

Анализ отобранных примеров олицетворяющих метафор, сопровождающихся переводом на русский язык (105 сочетаний имя+глагол из научной и научнопублицистической литературы), дает возможность говорить о следующих типичных ситуациях и переводческих решениях: 1) полное совпадение конструкции «имя плюс глагол» в оригинале и переводе с полным сохранением значения и метафорического образа; 2) лексическая замена одного из компонентов с некоторым изменением значения, но с сохранением образа; 3) в переводном тексте не сохраняется ни конструкция, ни метафорический образ оригинала, причем меняется частеречная принадлежность слов, их синтаксические функции и, наконец, опускается антропоцентричный глагол.

Первая группа включает в себя существительные, обозначающие силы природы, стихии и эмоции, что, по Лакоффу, совершенно естественно, поскольку они метафоризируются как живые существа, так что такая трактовка почти универсальна для языков. Именно поэтому русский перевод фактически калькирует оригинал - gravity and the other forces that govern physics - гравитация и другие силы управляют физикой; those factors demonstrably were directly responsible for European conquests - факторы ответственны за завоевания; pressure threatens - давление угрожает, disease challenges болезнь бросает вызов и так далее. Стихии близки к силам природы - wind sighed (ветер вздохнул) или wind sprang up (поднялся), flames growled, ran up the walls, fire licked and raced up (пламя стонало, побежало вверх по стене, языки пламени лизали). Судьба, удача метафорически близки силам природы, необъяснимы как имеющие собственную волю живые существа, и этим качеством они награждаются в обоих языках, например, fortune presents (судьба дарит).

Поскольку эмоции и физические состояния (emotional states), по Дж. Лакоффу и М.Джонсону, это 'entities within a person', то неудивительно, что the smile left his face 
(улыбка сошла у него с лица) или a smirk plays around the edges of his lips (на губах играет ухмылка). Эти и другие подобные примеры полного англо-русского соответствия опять же укладываются в общее для большинства языков и культур представление об эмоциях как самостоятельных, зачастую неподвластных человеку силах или живых существах.

Разного рода механизмы и устройства, выполняющие предписанные им функции как бы самостоятельно, также вполне логично одушевляются, что можно увидеть не только в их употреблении с глаголами одушевленной семантики, то и в том, что наделяются родом - женским или мужским. Речь здесь в первую очередь - о скрытой категории рода в английском языке, когда такие существительные заменяются не местоимением общего рода (it), а женского (she) или мужского (he), в зависимости от того, с живым существом какого рода соотносится в сознании говорящего данное устройство. Так, например, об автомобиле люди могут сказать give her some gas, если воспринимают его как существо женского пола, или give him a push, если для них машина - существо мужского пола. В таких языках, как английский, категория одушевленности/неодушевленности тесно переплетена с категорией рода, и они, как известно, часто выражаются одновременно (см. Масленникова 1999).

Одушевленность механизмов иллюстрируется такими примерами в обоих языках, как the machine spat up a plastic spool (плеер выплюнул пластмассовую бобышку), the black Chevrolet hurried on across a country side (черный шевроле поспешил). С машинами сближаются поселения, постройки, части домов, мебель - cheap little houses crowded in (маленькие домики окружали его), the village stands on the high wheat plains (деревня стоит на высокой равнине), Storm windows shuddered in the empty bedrooms (От сильного ветра дрожали окна).

Близость между языками прослеживается и в отношении, то есть способности одушевлять, письменную речь, порожденные человеком тексты, и проводимые им исследования. Так, Chapter 2 prepares us for exploring effects (Глава 2 подводит нас к...), Chapter 6 explores the numerous factors (Глава 6 рассматривает многочисленные факторы), a Chapter 18 returns to the problem (Глава 16 возвращается к проблеме...), тогда как detailed archaeological studies have shown (археологические исследования показали...).

Таким образом, очевидно, что силам (физическим, природы), эмоциям и их проявлениям, механизмам, и наконец, письменным и устным текстам, в обоих языках (и, видимо, не только в них) свойственна, пусть метафорически перенесенная, категория одушевленности, благодаря чему эти единицы используются вместе с одушевленномаркированными глаголами без нарушения правил сочетаемости обоих языков.

Если говорить о лексических заменах, то они, как правило, затрагивают глагол, а не существительное, при этом используются приемы конкретизации и генерализации: It (the hypothesis) invites a search for ultimate causes - Она выводит нас на поиск удаленных, исходных причин заложенным в ней вопросом; Mosses offer my-steries as well, he told me Мхи тоже задают загадки, говорит мне Эллис; Water obviously offered protection against heat and flame, but also presumably provided more sustenance in the lean period that followed Вода, очевидно, защитила от жара и пламени, а также, вероятно, дала пищу в последовавшее голодное время; That consideration (to develop a unified synthesis) dictates single authorship - Условие единства требует единоличного авторства. Встречаются случаи, когда в английском сочетании метафоричность видна и не вызывает сомнений, тогда как в переводе она сильно «сглажена»: The town sits on the slope of a hill - Городок лежит на склоне холма; Our lifestyles invite epidemics - Наш образ жизни способствует эпидемиям. Наконец, нередко русский глагол в переводе оказывается полностью лишен одушевленной маркированности: However, this hypothesis offers only a proximate (firststage) explanation - Однако эта гипотеза представляет собой лишь ближайшее (то есть первое по порядку) объяснение; Perhaps cold climates require one to be more technologically inventive to survive... - Возможно, выживание в холодных климатических условиях требует от человека большей технической изощренности... Крайней степенью утраты 
одушевленной маркированности при переводе являются те случаи, когда глагол в переводе опускается: this book attempts to provide a short history of everybody for the last 13,000 years - Эта книга - моя попытка кратко изложить историю всех людей, живших на планете за последние тринадцать тысяч лет.

Самые яркие расхождения между языками наблюдаются, когда в переводе происходит изменение синтаксической функции исходного подлежащего: That year also saw the death of Dmitri Mendeleyev - В тот год умер Д.Менделеев; The following 1,500 years saw the outpouring of Chinese technological inventions - В последующие 1500 лет мир увидел...; The nineteenth century witnessed an enormous growth - В 19 веке произошел резкий рост; some parts of the world developed literate societies - В некоторых частях света появились просвещенные общества; Small towns are equally unhelpful in offering distinguishing features - У маленьких городков нет никаких отличительных черт; The guide book referred to it as picturesque - в путеводителе его называли живописным; daily life still holds enough unpredictability - в нашей повседневной жизни все еще много непредсказуемого; In Italy, the national lottery omits the number thirteen - В Итальянской национальной лотерее не исполь-зуется номер 13; The ten cents carried him across the ferry to... - За десять центов он переправился на пароме в...; Most books that set out to recount world history concentrate on... - Авторы, которые берутся за изложение всемирной истории, как правило, сужают свой предмет до... .

Подлежащее оригинала в переводе начинает выполнять функцию обстоятельства причины и в тех случаях, где выстраиваются каузативные отношения: Bad-luck superstitions still keep many people from walking under a ladder - Многие люди из-за дурных примет до сих пор предпочитают не ходить под лестницей; It (age) makes you ache and muddies your head... - Боль и помутившийся рассудок - вот его приметы; Ink-circled names populated the map - Карта кишела обведенными в кружочек названиями.

Можно заметить, что вероятность изменения синтаксической функции при переводе особенно высока в тех случаях, если: (1) подлежащее в исходном предложении характеризуется локативной, инструментальной или пациентивной семантикой или же (2) сказуемое выражено глаголом с каузативной семантикой.

Таким образом, можно сделать следующие выводы. Оба языка характеризуются большим количеством когнитивных метафор, общих для них, в рамках которых с одушевленными сущностями соотносится целый ряд разнообразных явлений и объектов (силы, эмоции, машины и механизмы, даже слово и текст), что помогает адекватно переводить как языковые, так и художественные метафоры. Однако, несмотря на наличие этого общего для двух языков фонда когнитивных метафор, между ними существуют значительные различия в том, что касается лексической сочетаемости и семантики синтаксиса, что с неизбежностью требует использования переводческих трансформаций. В проанализированной выборке те или иные трансформации характеризуют $70 \%$ примеров, среди которых наиболее частотными переводческими приемами оказались изменение синтаксической структуры предложения и лексические замены.

$$
* * *
$$

1. Lakoff G., Johnson M.. Metaphors We Live By. - Chicago and London: The University of Chicago Press, 2003. $-256 \mathrm{p}$.

2. Low G. The paper thinks...: Investigating the acceptability of the metaphor "an essay is a person"//Researching and Applying Metaphor. - CUP, 1999. - p. 221-248.

3. Šeškauskienè I. The Paper Suggests: Inanimate Subject + Active Verb in English Linguistic Discourse//Kalbotyra. - 2009. - № 60 (3). - pp. 84-93.

4. Вежбицкая А. Язык. Культура. Познание. - М.: Русские словари, 1996. - 416 с.

5. Масленникова А.А. Скрытые смыслы и их лингвистическая интерпретация. Диссертация на соискание ученой степени доктора филологических наук. СПбГУ, 1999.

6. Юрков Е.Е. Метафора в аспекте лингвокультурологии. Автореферат на соискание ученой степени доктора филологических наук: 10.02.01. - СПб, 2012. 


\section{Гулиева Г. \\ О темпорально - метафорических моделях на азербайджанском и английском языках \\ Наџиональная Академия Наук Азербайджана Институт Языкознания (Азербайджан, Баку)}

doi: $10.18411 / \mathrm{sr}-10-08-2017-14$

idsp: 000001:sr-10-08-2017-14

\section{Аннотация}

В статье делается такое заключение, что темпоральными метафорами, независимо от того, присутствуют ли в ее составе темпоральные единицы, должны считаться метафоры, образующиеся посредством единиц, несущих темпоральную семантику и не несущих темпоральную семантику. Существует ряд моделей темпоральных метафор, и использование этих моделей на различных языках проявляется на различных уровнях. То есть, модель, которая плодотворно используется в одном языке, может отличаться своей пассивностью на другом языке. В работе на основе примеров применяются самые широко распространенные модели метафор на английском и азербайджанском языках «человек - время», «животное - время». В модели «человек - время» такие лексические единицы, как жизнь, возраст, бытие, проживание, связанные с человеком и имеющие в составе временной критерий, принимают активное участие в метафоризации. В метафорах, возникающих по модели «животное - время», смысл формируется на основании ассоциативных значений, которые создаются у человека от названий животных или частей тела животных. В модели «животное - время» больше метафор, несущих отрицательное содержание. Темпоральные метафоры также представляются путем использования таких свойственных времени особенностей, как непрерывное движение, периодическое движение. В таком случае наряду с перенесением времени на человека, человеческую жизнь, метафора может строиться на его отождествлении с рекой, волной, ветром и т. д. С этой точки зрения интересными представляются такие метафоры, как время - река, время - волна.

Ключевые слова: лингвистика, метафора, темпоральная метафора, темпоральные модели.

Метафоризация, сущность и функции метафоры в лингвистике всегда находились в центре внимания. Исследователи, принимая метафоризацию и метафору в качестве многопланового действия, стараются изучить ее различные аспекты (формальные, семантические, прагматические, этнокультурологические, психолингвистические) $[7 ; 8 ; 9$; $10 ; 11 ; 12]$. Во всех случаях формальная сторона метафоры и метафоризации принята как замена основного смысла предмета речи переносным смыслом. В словаре «Толковых лингвистических терминов» метафоризация разъясняется, как расширение смыслового объема слова за счет переносных смыслов, то есть, как усиление экспрессивных признаков слова $[1$, с. $156 ; 13$, с. 232]. На самом же деле, метафора и метафоризация являются сложными филологическими явлениями.

В исследовательских работах, посвященных в лингвистике метафоре, широко используется когнитивный метод, выдвинутый Дж. Лакоффом и М. Джонсоном [6, с.]. В данном методе метафоризация или же иносказание, охватывающие возникновение метафоры, принимаются в качестве когнитивного механизма, а в механизме основным является взаимовлияние двух систем знания. Первая структура является источником, а вторая объединяет в себе цель метафоризации.

Несмотря на то, что в любом языке имеются как схожие, так и отличные черты метафор, в общем разъяснении метафоризации среди исследователей существует единство мнения [16, с. 9]. 
Языковые единицы по - отдельности и в единстве друг с другом выражают различные смыслы. Смысловая черта языка отражает события, происходящие в реальной действительности, имевшие место или же которые могут произойти в будущем, а также, отношение людей к этим событиям.

Переносное значение слова исходит из ее метафоризации. Смысл является системой сложных отношений. Переносный смысл является результатом возникновения новых смыслов по мере развития номинативного смысла. «Переносный смысл - это слово или выражение, опосредованно используемое с целью художественной выразительности предметов или понятий. Любое иносказание возникает в результате взаимных отношений возникающих в сознании предметов и событий» [1, с. 163].

Метафора является достаточно сложным и широко распространённым видом иносказания. Несмотря на то, что метафорический смысл возникает путем переноса названий по сходству и отнесения их к иным названиям, ее формализация относится и к индивидуальным сходствам и субъективным переводам. С этой точки зрения существует очень много индивидуальных видов метафор, образующихся на основе модели человек время, или схожих с индивидуальным способом [15, с. 25].

Метафора является осознанием действий и качестве неизвестного предмета посредством схожих качеств и действий известного предмета. «Иными словами, метафорой называется слово, которое во время воспроизведения иным словом переводит на себя качества и признаки, относящиеся к иному предмету или явлению» [4, с. 152].

Согласно сходству, аналогии использование слова или выражения в переносном смысле образует метафору. В языке существуют номинативно - функциональные типы метафоры. Эти типы проявляются в таких взаимосвязях, как предметный / беспредметный, дескриптивный / оценивание, нейтральность / экспрессивность, образность / не образность и т. д.

Их семантика определяется по этим ярусам. Уточняются границы типов метафоры. Эти типы указаны ниже: идентичные метафоры, предикативные метафоры, образные эстетические метафоры, оценивающие эстетические метафоры, эмотивные метафоры. Несмотря на то, что все эти типы отмечаются в моделях «человек - время», «растение время», «живой - время» и т. Д., могут и не образовываться. Еще одно качество метафор это то, что они внедряются в сам контекст. При изоляции от контекста они теряют свою метафоризацию.

Метафора создается человеком, и в это время в сознании человека сталкиваются отношения и связи между различными отраслями знания, происходит переход от одной сферы к другой. В создании моделей метафоры используется два полюса. Единица семантической области, находящейся в одном из этих полюсов, находится в первичной, то есть, не метафоризированной форме, а другой полюс образует область метафоризированного смысла. К вопросу темпоральной метафоры можно отнестись с трех направлений. Первое направление - это метафоризация единиц языка, не имеющих темпорального смысла, и выражение темпоральности; второе направление - это возникновение новой единицы с темпоральным смыслом в результате метафоризации темпоральных единиц; наконец, третье направление - метафоризация темпоральных единиц и удаление от прежнего темпорального смысла.

Мы пришли к такому заключению, что темпоральными метафорами, независимо от того, присутствуют ли в ее составе темпоральные единицы, должны считаться метафоры, образующиеся посредством единиц, несущих темпоральную семантику и не несущих темпоральную семантику.

Исследование темпоральных метафор дает возможность для создания ряда рабочих моделей. Отметим, что использование этих моделей на различных языках проявляется на различных уровнях. То есть, модель, которая плодотворно используется в одном языке, может отличаться своей пассивностью на другом языке. 
К широко распространённым моделям темпоральных метафор относятся следующие: 1) “человек - время”; 2) “животное - время”; 3) “растение - время”; 4) “место время".

А.Я. Воробьев при изучении особенностей использования темпоральных метафор в художественном тексте, также, провел расчеты в связи с уточнением степени применяемости различных моделей. Автор приходит к такому выводу, что на английском языке в художественной литературе к широко распространённым моделям темпоральных метафор относятся следующие: 1) время - запас; 2) время - объем; 3) время - место; 4) время - круг // время - бесконечность; 5) время - враг [14, с. 8] .

По нашему мнению, А.Я. Воробьев создавал модели метафоры в некотором отличающемся виде. Здесь более общими являются не понятия «человек», «животное», «растение», а основу модели составили специальные объекты и предметы, связанные с данными понятиями, а также, абстрактные понятия. Дело в том, что эти модели основываются на критерий влияния времени на живые существа. Верно, на различных языках отношение к формированию категории одушевленный / неодушевленный тоже разное. Например, на азербайджанском языке животные и растения не вносятся в одну группу одушевленных. Определение группы одушевленных только по человеку свойственно и некоторым другим языкам. Однако, отнесение животных, птиц и растений к одушевленным существам принято в ряде языков. С логической точки зрения растение тоже восходит, растет и развивается. Развивается и после определенного времени завершает свое существование. Одушевленность животных проявляется более наглядным образом. Они тоже рождаются и умирают. А в моделях Воробьева принимается во внимание влияние времени не только на человека, животных и растения, и в целом, связь происходящих на самом деле событий со временем. А. Воробьев пишет: «в соответствии с тем, что происходит в жизни человека, последовательность каких событий заполняет его временной континуум, и каковы субъективные отношения человека к этим событиям, встречаются такие выражения времени, как дорогой (dear time, precious time), возмутительный (sluttish time), приятный час времени (happy hours), любимый (sweet hours), священный (holy hours), нечистый (hours of dross), необычный день времени (curious days), ehtiraslı (lusty days), украшающий (time-bettering days), ценные моменты / минуты (precious minutes), плохие моменты / минуты (wretched minutes)»

Это проявляется и при выражении чувств в связи с прохождением времени. Например, быстроходное / бегущее / улетающее время (swift-footed time), время, не знающее покоя (never-resting time) vә т.д. [14, с. 8].

Анализ темпоральных метафор показывает, что область модели «человек - время» крайне большая. Концептуальная область человека проявляется в качестве основных источников метафорного переноса. Область делится на такие группы, как части тела, характер, различные действия, физиологические процессы. Из них более широко применяются части тела и свойственные человеку действия и деятельность. При определении подобных метафор за основу берется отнесение свойственных человеку качеств к темпоральным единицам. Для определения метафоры важный признак связан с личностным качеством. Например, глаза города открылись, день закрывал глаза, ночь напевала свою песню, руки времени вцепились за горло Мардана и душили его, зима накрасила щеки девушек, я зима, зима, зима, я накрасила щеки девочек; ночь забыла все прошлое; весна облачилась в зеленое приданое; весна украшалась, весна вдыхала воздух в землю; ночь превратилась во врага человека и т. д.

В англоязычной художественной литературе можно столкнуться с отождествлением времени с цыганкой.

Time, you old gipsy man,

Will you not stay,

Put up your caravan

Just for one day? (R.Hodgson). 
Автор, принимая во внимание постоянное движение времени, отождествляет его с пожилой цыганкой (old gipsy man).

В модели «человек - время» такие лексические единицы, как жизнь, возраст, бытие, проживание, связанные с человеком и имеющие в составе временной критерий, принимают активное участие в метафоризации.

В толковом словаре азербайджанского языка слово «жизнь» поясняется следующим образом: «ЖИЗНЬ ис. [ар.] 1. Это физиологическое состояние человека, животного или растения с рождения до смерти. Один живет долго, другой мало. Т.Ш. Симург. Жаль, жизнь коротка, желания большие; каждый сотрясен этой заботой. М. Мушвиг» [3, с. 355].

Раскрытие смысла слова «жизнь» в качестве физиологического состояния немного не оправдывает себя. В качестве варианта - синонима в пояснении имеет место и слово «жизнь» (хаят) А в пояснении слова «хаят» второй смысл дается как «омур» (жизнь), а третий смысл связывается со временем. «Жизнь.... Ашраф еще не совершил в жизни никакого героизма. С. Рахман. Однажды в моей жизни возникнут ураганы. Жизнь вытолкнет меня из своей колеи. М. Араз. 3. Это период с момента возникновения одушевленного тела до его исчезновения» [2, с.358].

И. Тахиров на английском и на азербайджанской языках разделяет темпоральность, лексико - семантическую область на две лексико - семантические микрообласти. Автор делит слова, составляющие первую лексико - семантическую область на 7 лексико - семантических групп. A VII лексико - семантических групп подразделяет и поясняет в виде шести подгурпп. И.М. Тахиров пишет: «Среди выбранных слов можно столкнуться с такими, которые употребляются в функциях, эквивалентных функциям существительных, относящихся к данной области в определенных ситуациях. Темпоральный смысл подобных существительных понимается не посредственно, а опосредованно. Содержащийся в них временной смысл может существовать в их первичных лексико - семантических вариантах в имплицитном виде» [5, с. 120].

Слово «жизнь» (омур) в художественных текстах, в особенности, в поэзии по семантическому содержанию является широкоплановым. В его значении время во многих случаях имеет место как в явном, так и в имплицитном виде.

«Жизнь - это тоже долг в пятьдесят, сто лет»

Несчастны те, кто мало пишет и много живет,

Друг мой поэт, ищи свою жизнь не в годах,

А ищи ее в жизни написанной песни» (М. Ибрагим).

"Ömür də bir borcdur əlli il, yüz il,

Bədbəxtdir az yazıb, çox yaşayanlar.

Şair dost, ömrünü yaşında deyil,

Yazdığın nəğmənin yaşında axtar” [M.İbrahim].

В данном примере жизнь отождествляется с округленным периодом. Использованные в первой строке слова 50 лет, 100 лет, не выражают пределы продолжительности жизни. В качестве срока поэт выбирает период между 50 и 100 годами. Здесь содержится смысл времени от жизни до смерти. Несмотря на то, что в стихотворении явным образом не написаны понятия «человеческая жизнь», «человеческий возраст», «возраст песни», «продолжительность жизни песни», в сознании читателя словно создается последовательность смыслов, выражаемых этими словосочетаниями. В позиции метафорического словосочетания стоит словосочетание «продолжительность жизни песни». Также, как продолжительность жизни песни может быть короткой, точно также, она может превысить и сотни лет. Песня может быть позабыта в короткое время после чтения или написания. В таком случае песня словно умирает. В примере явным образом проявляется перенос жизни поэта на продолжительность жизни песни.

“Большинство страниц жизни - 
Обычные дни!

Торжества, роскошь -

Обычные дни" [М. Ибрагим].

В данном образце жизнь отождествляется с книгой. Это отождествление вытекает из словосочетания «страница жизни». Словосочетание «страница жизни» используется в смысле «день жизни». Если взять по - отдельности, соединение «страница - день» не подтверждают метафору. Однако, внутри контекста данная метафора реализуется. В художественной литературе отмечаются также такие переносы, как «день - лист», «год лист», неопределенный срок жизни - лист. В приведенном выше примере использовано отождествление «жизнь - 50 лет», «жизнь - 100 лет».

В стихотворении использовано также словосочетание «обычные дни». И. Тахиров отнес слово «день» к первой лексико - семантической группе лексико - семантической микросферы, отмечал, что оно является одним из единиц измерения и расчета времени [5, с. 119]. В словосочетании «обычные дни» временной смысл слова имплицитен. Безусловно, поэт соотносит обычные дни с значительными, запоминающимися днями.

Модель «животное - время» темпоральных метафор исходит из того, что животное является одушевленным существом. Возникает в результате влияния изменения времен на жизнь животных, а также, отождествления времени с различными животными.

"Qəza insanatı tənabdan asar,

Leyli-nahar - muşdu, cəhd eylər, kəsər,

Ojdaha ayaqdan çəkər sərasər,

Әlləşər, barmağı bala yetişməz." (Ашуг Алескер)

Слово «танаб» в данном стихотворении отождествляется с человеческой жизнью. Это, жизненная веревка. А день и ночь отождествляются с роком. День и ночь укрощают человеческую жизнь.

В метафорах, возникающих по модели «животное - время», смысл формируется на основании ассоциативных значений, которые создаются у человека от названий животных или частей тела животных. Крыса, мышь и т.д. относятся к цепи отрицательных образов. То, что они грызут и режут играет базовую роль для переноса. В приведенном выше примере словосочетание «отрезать веревку жизни» отражает укорочение и в итоге, завершение жизни путем смены мест дня и ночи или же их замены друг друга. В модели «животное - время» больше метафор, несущих отрицательное содержание. Такие метафоры, как когти времени, когти ночи, ужас ночи, продолжение ночи словно змея, превращение ночи в белого волка и т. д. обладают отрицательной коннотацией.

Темпоральные метафоры также представляются путем использования таких свойственных времени особенностей, как непрерывное движение, периодическое движение. В таком случае наряду с перенесением времени на человека, человеческую жизнь, метафора может строиться на его отождествлении с рекой, волной, ветром и т. д. С этой точки зрения интересными представляются такие метафоры, как время - река, время -волна. Волны, стремящиеся к берегу, движутся периодически и непрерывно. Волна ударяется о берег и возвращается. Происходит усиление и ослабление волны, но, непрерывное ее движение продолжается. Отождествление волны и времени встречается в сонетах В. Шекспира:

«Like as the waves make towards the pebbled shore,

So do our minutes hasten to their end;

Each changing place with that which goes before,

In sequent toil all forwards do contend.

Nativity, once in the main of light,

Crawls to maturity, wherewith being crown'd,

Crooked elipses 'gainst his glory fight,

And Time that gave doth now his gift confound.

Time doth transfix the flourish set on youth 
And delves the parallels in beauty's brow,

Feeds on the rarities of nature's truth,

And nothing stands but for his scythe to mow:

And yet to times in hope my verse shall stand,

Praising thy worth, despite his cruel hand»[ССонеты Шекспира. Стихи. william shakespeare. Sonet 60// http://www.stihi-rus.ru/World/Shekspir/65.htm].

Стремящиеся к берегу волны строятся друг за другом и словно защищают друг друга. Моменты времени тоже таковы. Они проходят один за другим и охраняют друг друга.

Если взять реальность, то существует берег, который достигается волнами. Однако, время не имеет берегов. Бесконечное течение времени - волны создает чувство вечности. Наименьшей единицей времени для В. Шекспира является минута. С этой точки зрения 60 - ая сонета словно указывает на то, что час состоит из 60- ти минут. Время в сонете отражается в качестве гонящих друг друга волн. Точнее сказать, здесь использовано отождествление минут с волнами. Минуты гонят друг друга, словно волны. (Like as the waves make towards the pebbled shore, So do our minutes hasten to their end). Созданное природой уничтожается волнами. Наряду с этим в сонете отражается вечность времени и жизни.

Несмотря на то, что первичные и дополнительные значения слов не очень то похожи друг с другом, различие уясняется посредством контекста. Контекст обнаруживает многозначность, метафоризацию слова.

Возможность слов создавать лексические соединения зависит от их семантики. В связи с тем, что темпоральная семантика связана со временем, она более склонна к метафоризации. Окружающие нас события отличаются своим разнообразием и пестротой. А за основной частью событий стоит время. Иногда это время конкретно, иногда неопределённо, а иногда факультативно и иррелевантно.

Таким образом, возникновение нового значения в процессе метафоризации не всегда происходит непосредственным путем. Предмет, события, вещи представляются в сознании, происходит сравнение и оценивание. Модели, из которых возникает метафора, формируются на основании нового языкового средства, репродуктивно - комбинаторных единиц.

$$
* * *
$$

1. Адилов М.И., Вердиева З.Н., Агаева Ф.М. Пояснительные термины языковедения. Баку, Маариф, 1989. $-394 \mathrm{c}$.

2. Пояснительный словарь азербайджанского языка. Т. ІІ. Баку: Шерг-Гарб, 2006. - 792с.

3. Пояснительный словарь азербайджанского языка. Т. ІІІ. Баку: Шерг-Гарб, 2006. - 672с.

4. Рафили М. Вступление в теорию литературы. Баку, издание АПИ, 1968. -234 с.

5. Тахиров И. Временная категория в азербайджанском и английском языке. Баку, Нурлан, 2007. -324 с.

6. Лакофф Г., Джонсон М. Метафоры, с которыми мы живем. Чикаго, 1980.134 с.

7. Левин С.Р. Терминалогия метафор. Балтимор: Джонс Хопкинс Пресс. 1977. 338 с.

8. Свитсер Э. От Этимологии до Прагматики. Метафорические и культурные аспекты семантической структуры. Кембридж, 1990. 174 с.

9. Ковесцес 3. Метафоры. Практическое представление. Пресса Оксфордского Университета, Инк., 2010. $396 \mathrm{c.}$

10. Садок Д.М. Фигуральная речь и лингвистика. Ин: Ортони А. Метафоры и мышление. Второе издание: Пресса Кембриджского Университета, 1993, стр. 42-58;

11. Шелестюк Г.В. Подходы к метафорам: структура, классификации, феномен когнатного распознавания // Публикация в интернете: 2006-11-10) DOI: https://d0i.0rg/l 0.1515/SEM.2006.069. 346 c.

12. Арутюнова Н. Д. Метафора и дискурс. // Теория метафоры: Сборник: М.: Прогресс, 1990, с. 5-32.

13. Ахманова О.С. Словарь лингвистических терминов. 2-е изд., стер. М: Изд-во «Советская энциклопедия», 1969. $607 \mathrm{c.}$

14. Воробьев А.Е. Темпоральная метафора как механизм когнитивного моделирования действительности (на примере произведений англоязычной художественной литературы): Автореф. дисс. ... канд. филол. наук. Москва, 2011. 157 с.

15. Калинин И.В. Лексика русского языка. Москва, Изд-во МГУ, 1971. 240 с.

16. Тихомирова Е.А. Лингвистический анализ тропа: Метофора- олицетворение в русских и белорусских текстах начала XX века. Автореф. дисс. ... канд. филол. наук. Минск, 1991. 173 с. 


\section{Исламова А.К. \\ Стратегия глобализации художественного пространства в романе К. Уилсона «Башня}

(Россия, Санкт-Петербург)

doi: $10.18411 / s r-10-08-2017-15$

idsp: 000001:sr-10-08-2017-15

\section{Аннотация}

В статье устанавливается функциональная зависимость между формированием концептуальной схемы и авторской стратегией ее реализации в эпической перспективе рассматриваемого произведения. Определение онтологических, гносеологических и эстетических концептов схемы сопровождается анализом их содержательных и формообразующих связей с проектом и созданием картины мира и человека в нем в масштабах глобального социума. Итоги предпринятого опыта позволяют заключить, что стратегическая цель глобализации состояла в гуманистическом обосновании результатов прогресса, а средством достижения этой цели явилось изображение индивидуальной судьбы как части всемирно-исторического опыта.

Ключевые слова: Художественное пространство, эпический концепт, концептуальная схема, стратегия глобализации, архитектоника жанровой формы

\section{Abstract}

The article states the functional relation between the formation of the conceptual scheme and the author's strategy of its realization in the epic perspective of the novel "TheTower" by C. Wilson. The ontological, epistemological and aesthetic concepts of the scheme are viewed in the network of their meaningful and formative connections with the creation of the global picture of the world and man in it in the novel considered. The study is followed with the conclusion that the writer's strategy of globalization is aimed at the correlation of natural and human factors of civilization and that this aim is achieved in the novel due to representation of individual life as part the total historic experience.

Keywords: Epic perspective, epic concept, conceptual scheme, strategy of globalization, architectonic of genre form

Английский романист Колин Уилсон вошел в литературу в середине XX века и принял традиции социальной вовлеченности и моральной ответственности писательского труда в качестве ведущих направлений творческого пути. С течением времени его произведения сложились в летопись поворотных событий, включающую философскую оценку общественных конфликтов и гуманистическое обоснование их решений. Опыт междисциплинарных изысканий выразился в научно-публицистических трактатах и эссе, а художественной книгой итогов сталатетралогия «Мир пауков», где автор запечатлел актуальную действительность с позиций пост-современности, иначе - с точки зрения потенциальных угроз и будущих возможностей человеческого бытия. Футурологический проект выполнен в форме эпической полимодели из цикла романов «Башня» (1987), «Дельта» (1987), «Маг» (1992), «Земля теней» (2003). Циклический принцип жанровой организации поддерживается централизованной концептуальной схемой, которая заложена в архитектонику первой книги и задает онтологические, гносеологические и эстетико-художественные концепты всех составных частей.

В романе «Башня» онтологические параметры концептуальной схемы определяются внешними факторами социального и культурного характера. История свидетельствует о том, что в течение двадцатого столетия планетарное сообщество не однажды находилось на грани фатального кризиса, когда извечный вопрос литературы о судьбе человека в мире представал как глобальная проблема выживания в условиях 
беспрецедентных войн, смертельной атомной опасности, стремительной деградации среды обитания вследствие переизбытка и экспансии техники. Обобщая результаты отечественных и зарубежных исследований в области философии глобальных проблем, А.В. Турчин и М.А. Батин подчеркивают: «Каждый из глобальных рисков может охватить всю поверхность Земли настолько быстро, что люди не успеют подготовить средства защиты от него и при этом он обладает такой силой, что может уничтожить каждого человека» [5 c. 197].Очевидные факты катастрофического развития цивилизации составили бытийное основание для разработки прогностического сценария К. Уилсонав масштабах тотального социума: «Все, что необходимо человеческому роду для вхождения в совершенно новую стадию эволюции - это сущностное сознание того, что он, выражаясь образным языком, представляет собой единый организм» [10, p. 236]. Культурные предпосылки онтологического концепта в романе «Башня» были обусловлены, прежде всего, исчерпанностью мировоззрения, в рамках которого социальная и природная реальность могла подвергаться насильственному вторжению со стороны человека в целях ее рационального преобразования. Американский философ Ш. $\mathrm{X}$. Ролстон фиксирует отказ от агрессивного вмешательства в существующий порядок вещей как признак преодоления разрыва между развитием цивилизации и бытием природного мира: «Суть происшедшего изменения - в снятии любого жесткого барьера между человеком и миром» [3, с. 278]. Поддерживая политику ненасильственных компромиссов в области социологии,К. Уилсон особо выделяет их значение для отношений личности с общественным окружением: «Реальная проблема заключается в том, чтобы найти меру единства здорового индивидуализма и здорового общества» $[9, \mathrm{p}$. 49].

Отстранение писателя от прогрессистской установки на переустройство внешнего мира повлекло за собой смещение когнитивного концепта романа «Башня» из сферы объективной реальности в сторону субъекта научного знания и практической деятельности. М. Фуко, представитель постмодернистской философии, полагает, что повышение статуса познающего субъекта является самоочевидной тенденцией новой рациональности, но усматривает в этом явлении гносеологическое искажение пространства науки на пороге классического и современного периодов ее истории: «На этом пороге впервые возникло то странное формообразование знания, которое называют человеком и которое открыло пространство, присущее наукам о человеке» [7, с. 37]. К. Уилсон высказывает противоположное суждение о ценности гуманитарного знания и настаивает на том, что исключение феномена человека из поля исследований чревато нарушением закона объективизма в науке: «Я пришел к тому, что вся моя жизнь была подготовкой к работе, которой я занимаюсь сейчас: открытие новой научной дисциплины, способной одновременно и к подлинной объективности, и к признанию того факта, что человеческие существа и человеческая жизнь сами по себе являются частью загадки» [11, p. 275].Писатель совмещает гуманитарную направленность и эмпирические диспозиции концепта знания за счет внедрения в него эволюционного принципа процесса, а также трактовки человека в качестве объекта и субъекта данного процесса на том основании, что человеческий разум обладает уникальной способностью к «сознательной постановке эволюционной цели» [9, р. 182].

Экстра-литературные предпосылки концептуальной схемы составили достаточно прочный методологический фундамент для создания такой картины человеческой реальности, которая включала бы ее возможность стать иной реальностью. В романе «Башня» заданная цель достигается посредством разработки эстетического плана в жанре философской фантастики, поскольку его формульная структура допускает репрезентацию вероятных ситуаций как несомненных и реальных в границах научной достоверности и художественной условности. Выстраивая эпическую перспективу плана, писатель относит eе хронологические границы к неопределенно далекому будущему и устанавливает пространственные измерения на уровне глобальных значений. Поскольку этот формообразующий конструкт включал в себя прогностическое содержание 
концептуальной схемы, тоее перспективные проекции на эпический горизонт создают облик несчастной планеты, отражающий последствия негативных факторов цивилизации в сюрреалистической картине будущего. Земной пейзаж развертывается здесь как бесплодная пустыня, где обитают гигантские насекомые и страдают преследуемые ими люди: «Сколько люди себя помнили, на них все время охотились. Скорпионы, жукискакуны, полосатые скарабеи, кузнечики-гиганты. Но чаще всех пауки-смертоносцы» [6, c. 9]. По отношению к жанровой архитектонике романа «Башня» и всей эпопеи, сюрреалистическая стилизация первичной экспозиции представляет собой один из способов глобализации художественного пространства, потому что она позволяет соединить детальное описание вводной сцены с универсальной мифологической энигмой - загадкой о происхождении тех таинственных сил, которые властвуют над природой и человеком.

Прослеживая становление фантазийных жанров, Е.Н. Ковтун находит их истоки в глубокой древности, когда мифологический вымысел определял законы построения форм в словесном творчестве: «Изучение этих законов невозможно без учета происхождения вымысла, который, подобно искусству в целом, уходит корнями в первобытную мифологию, сохраняя, нередко, более отчетливо, чем вся остальная литература, связь с мифологическими принципами осмысления и отражения человеческого бытия» [4, с. 33]. В фантастическом романе «Башня» гено́м мифологических коннотаций привносится в структуру пространственной формы при посредничестве центрального персонажа, который прокладывает дорогу жизни в окружающем мире, развертывая эпическое полотно и осмысляя открывающиеся вещи реальности в их значении для человека. Описывая этот путь по образцам мифологических сказов о деяниях великих подвижников, автор романа традиционно наделяет героический образ-характер необычайными свойствами, но отступает от архаических понятий о них. В семиотической теории Р. Барта понятийное наполнение мифа подвержено историческим изменениям в рамках аутентичной идеографической формы: «Миф есть истая идеографическая система, где формы еще монтированы представляемым им понятием, но отнюдь не покрывают им всей своей изобразительной целостности» [1, с. 287] Приведенное суждение вполне применимо к определению функциональной зависимости мифологического прообраза от жанровой формулы современной фантастики в романе «Башня», потому что здесь высшими мерами героических достоинств являются не воинские доблести, а выдающиеся способности ума, многократно превышающие возможности обыденного сознания. Автор выдвигает на передний план обладателя таких качеств и доверяет ему разгадку тайны мира пауков: «Смертоносцы, скажем, покорили человечество оттого, что познали людские умы. Получается, что и человек, познав сущность паучьего разума, сможет одержать когда-нибудь верх над смертоносцами!» [6, с. 103].

С продвижением главного героя по имени Найл в центр эпической перспективы проблема судеб человечества приобретает личностное измерение, а путь жизни протагониста и поле-горизонт его сознания становятся множителями художественного пространства. В сложившейся системе координат, стратегия глобализации направляется на изображение индивидуального бытия как части всемирно-исторического опыта. Эта цель достигается при помощи многообразного набора писательских инструментов, включая описание жизненных обстоятельств текущего времени в свете событий минувших эпох. Отдельные фрагменты исторической ретроспективы восстанавливаются в процессе вторичной экспозиции, когда герой обнаруживает в окрестностях следы древней цивилизации и приходит к признанию былого могущества человеческого рода под впечатлением от различных памятников старины, а более всего - великолепной Белой башни, известной в народе как неприступный и таинственный «ментальный за́мок». Расстановка дальних исторических вех совмещается с обозначением относительно недавних поворотных событий, которые привели большинство людей в рабство к смертоносцам и возвратили других к первобытному состоянию в пустынных или подземных резервациях. Разметка нового участка историографической карты 
осуществляется по свидетельству старейшины рода о том, что роковой поворот начался с Великой Измены, когда правящая элита выдала паукам секреты человеческого разума из корыстных побуждений и обрекла своих собратьев на медленную деградацию и смерть: «Оказывается, между людьми и пауками шла долгая и жестокая борьба, и пауки одержали в ней верх лишь потому, что научились понимать человеческие мысли» [6, с. 100]. Сравнив позиции людей на карте мира пауков в прошедшем и настоящем времени, Найл убеждается в существовании внутренних истоков зла в человеческом сообществе, но находит и возможность для их пресечения в тех гуманистических ценностях, которые защищены непроницаемыми стенами Белой башни от посягательств пауков и недостойных людей.

Жизненная стезя героя сплелась с общей линией человеческого бытия в бесчеловечном мире после того, как смертоносцы захватили юношу в плен, убив отца и обратив в рабство других членов семьи. Это трагическое событие дает начало череде эпизодов и происшествий, составляющей сюжетно-драматическую основу пути протагониста. Подобно другим своим сородичам, Найлу довелось пережить животный страх в когтистых лапах смертоносца, отчаяние бесправного узника, тяжесть подневольного труда. Однако, в отличие от них, он сумел найти неторную тропу выхода из состояния господства и подчинения благодаря редкостным способностям ума и интуиции и целеустремленной воле к их совершенствованию: «Овладей люди навыками внедряться и управлять мыслями, дни паучьего господства окажутся сочтены. Как какоенибудь дрессированное насекомое, закабаленный разум - это замок, к которому подходят несколько ключей» [6, с. 317]. Шведский исследователь К.Г. Бергстрём полагает, что для К. Уилсона главным фактором решения гуманитарных проблем является реализация скрытых ресурсов сознания: «Это дорога к внутренней свободе и силе, ключ к человеческим возможностям» [8, p. 143]. Однако в романе ключевая сцена исхода из мира насилия отмечена не вспышкой озарения сознания, а моментом нравственного выбора между недостойной жизнью по законам пауков и смертельным риском во имя законов человечности. Найл отказывается от предательского сговора с пауками против инакомыслящих людей, но спасается от жестокой казни за неповиновение в стенах Белой башни, которая не открывала их ни для кого прежде.

С проникновением героя в «ментальный замок» сюжетное движение замедляется, и драматическое повествование сменяется эпическим описанием естественной и общественной истории мира пауков. Французский структуралист Ж. Женетт отчетливо разграничивает два вида дискурса по признакам их жанрообразующих функций в системе пространственных и временных координат произведения: «Повествование занято поступками и событиями как чистыми процессами, а потому делает акцент на темпорально-драматической стороне рассказа; описание же, напротив, задерживая внимание на предметах в их симультанности и даже их процессы рассматривая как зрелища, словно приостанавливает ход времени и способствует развертыванию рассказа в пространстве» [2, с. 291]. Жанровая организация текста в романе «Башня» отвечает приведенному определению, но с той оговоркой, что обе формы литературного письма здесь равно причастны к авторской стратегии глобализации художественного мира и эстетической деятельности героя. В драматическом повествовании мир подает себя герою, вовлекая в действие и увеличивая поле его умственного видения по мере накопления опыта и с течением времени. В эпическом описании, когда герой осваивает научное и культурное наследие предков в «ментальном замке», картина мира и человека в нем приобретает глобальные масштабы благодаря усвоенному навыку субъекта воспринимать объективную реальность в широком горизонте сознания. Если главным достижением стези опыта явилось усвоение этического принципа человеческого бытия, то из уроков научного знания во время остановки в пути герой извлекает правило эволюционного процесса всего сущего на Земле. Сделанные открытия давали исчерпывающее объяснение сложившемуся порядку вещей: пауки превзошли всех прочих обитателей планеты, потому что жили по законам естественной эволюции и сделали 
огромный скачок в своем развитии после великой космогенной катастрофы; люди же потерпели сокрушительное поражение в битве за первенство, поскольку нарушили моральный закон своего единства. С этими идеями Найл покидает Белую башню и возвращается в мир пауков, чтобы ответить на вызов императива долга: «Закон жизни гласит: выживает сильнейший. Если вам не по силам одолеть смертоносцев, значит вы недостойны свободы, а пауки имеют право на то, чтобы и впредь властвовать над Землей» $[6$, c. 390].

По возвращении героя на стезю опыта эпическое пространство приобретает социальные измерения. Нелегальное положение опасного вольнодумца обрекало Найла на участь бесприютного скитальца и, вместе с тем, создавало возможность единого видения многообразных сторон жизни, а также способов ее общественной и государственной организации в империи пауков. В образовавшейся перспективе возникает картина классового общества, включающего в себя смешанные элементы исторических формаций, но равномерно пронизанного силовыми линиями тоталитарной власти на всех уровнях иерархии. Поскольку насильственное отчуждение свободы было испытано Найлом как отсутствие фундаментального условия человеческого существования, то он выходит на арену открытой борьбы с тоталитаризмом вместе с единомышленниками из числа рабочих, готовых отстаивать свои насущные интересы в отношениях с паучьей аристократией и буржуазным сословием жуков-бомбардиров. Однако протестные акции перерастают в кровопролитие такого масштаба, что антагонисты могли истребить друг друга, если бы обоюдное возмущение нравственного сознания и здравого смысла не заставили их искать мирного соглашения. Найл был привлечен к судебной ответственности как главный зачинщик беспорядков и приговорен к изгнанию по решению суда, который принял во внимание компромиссный договор враждующих сторон и бескомпромиссное обвинение пауков в посягательстве людей на предустановленные основы мироустройства: «Они не способны жить в мире. В конце концов боги устали от них и сделали хозяевами нас. И с той поры Земля живет в мире» [6, c. 553].

Перед изгнанником простирался долгий путь к пониманию того, что закон естественной эволюции распространяется на общественную жизнь, а принцип этической целостности бытия объединяет всех живых существ в моральный универсум на планете. Открытие и постижение этих истин составляли новые этапы опыта и знания, которые подлежали художественному описанию и философскому осмыслению в глобальной эпической перспективе «Мира пауков».

$$
* * *
$$

1. Барт Р. Мифологии / Пер. с фр. С. Зенкина. - 3-е изд. - М.: Академический проект, 2014. - 351 с.

2. Женетт Ж. Фигуры. В 2-х томах. Т. 1 - М.: Изд-во им. Сабашниковых, 1988. - 472 с.

3. Ролстон Ш. Х. Существует ли экологическая этика? / Глобальные проблемы и человеческие ценности / Пер. с фр. и англ. / Сост. Л И. Василенко, В. Е. Ермолаева. - М.: Прогресс, 1990. С. 258-288.

4. Ковтун Е. Поэтика необычайного. Художественные миры фантастики, волшебной сказки, утопии, притчи и мифа. (На материале европейской литературы первой половины XX века). М.: Изд-во МГУ, 1999. $-306 \mathrm{c}$.

5. Турчин А. В., Батин М. А. Футурология/ХХІвек. Бессмертие или глобальные катастрофы? - М.: БИНОМ. Лаборатория знаний, 2013. - 263 с.

6. Уилсон К. Мир пауков. Кн. 1. Башня / Пер. с англ. А. Шабрина. - М.: Эксмо; СПб.: Домино, 2010. - 560 c.

7. Фуко М. Слова и вещи. Археология гуманитарных наук / Пер. с фр. В.П. Визгина, Н. С. Автономовой. СПб.: Изд-во А-cad, 1994. - 406 с.

8. Bergström G. An Odyssey to Freedom: Four themes in Colin Wilson's novels / Acta Universitatis Uppsalientis. 47. - Uppsala, Stockholm: University of Uppsala, 1983. 160 p.

9. Wilson C. Beyond the Outsider. - London: Pan Books, 1966. - 255 p.

10. Wilson C. The Philosopher's Stone. - London: Baker, 1969. - 315 p.

11. Wilson C. The World of Violence. - Boston: Houghton Mifflin Co., 1963. 272 p. 


\section{Кирдеева А.М. \\ Семантика и функционирование глаголов восприятия в современных англоязычных художественных текстах}

Балтийский Федеральный университет имени И.Канта (Россия, Калининград)

doi: $10.18411 / \mathrm{sr}-10-08-2017-16$

idsp: 000001:sr-10-08-2017-16

\section{Аннотация:}

Статья посвящена особенностям функционирования глаголов восприятия в англоязычных художественных текстах, рассматриваются примеры многозначности некоторых глаголов

Ключевые слова: Семантика глаголов восприятия, многозначность, функционирование глаголов, каналы восприятия, базовые глаголы.

Тема восприятия в настоящее время широко исследуется многими лингвистами. За последнее время тема стала актуальной для многих исследователей - лингвистов (Дмитриева Е.Г, Козюра Т.Н. Кузнецова С.С. Сафонова А.А, Чумакова Г.В,). Восприятие как процесс, вызывает интерес исследователей в психолингвистике, нейролингвистике, а также у зарубежных исследователей. Глаголы восприятия передают отражение современной картины мира. Существует немало статей посвященных особенностям употребления глаголов восприятия (Фатхутдинова В.Г, Петрова И.П. ,Слепцова Л.А, и.т.д.) Согласно когнитивной лингвистике, человек воспринимает информацию, а затем он посредством своих внутренних состояний передает данную информацию тем, самым образую свою картину мира. «Прибегая к метафоре, можно назвать глаголы восприятия «воротами» из мира объективной реальности в мир языковой, они обозначают первый производный и непроизводный контакт человека с объективным миром.»[5;73]

Лексикография всегда ставила вопрос перед теоретической семантикой о создании исчерпывающих значения слов. Основными элементами языка является, слово и его лексическое значение, в нем отражается веками, хранится социально исторический опыт носителей данного языка. «Передача лексических значений осуществляется на коммуникативном уровне, именно на этом уровне оно представлено наиболее полно, многообразно, во всех его разновидностях и комплексном взаимодействии.»[5;26]

«Известно что теоретическая семантика предшествующей эпохи занималась почти исключительно вопросом о том, как слова значат. Именно этому посвящено учение о способах развития значений - сужении и расширении, дифференциации и аттракции, метафоре и метонимии и т. п., а также более тонкие наблюдения над направлением переносов - от пространственных значений - к временным, но не наоборот, от потіna anatomica - к именам физических предметов, но не наоборот; от названий свойств, воспринимаемых осязанием, обонянием и вкусом, - к названиям свойств, воспринимаемых зрением или слухом, но не наоборот; и ряд других.» $[1 ; 6]$

Глаголы восприятия представляют собой традиционно пять сенсорных систем человека, зрение, слух, обоняние, осязание и вкус. В английском языке каждая группа глаголов, как и в других языках, образует свое микрополе глаголов сенсорных систем. Среди данных глаголов есть наиболее часто употребляемые глаголы, частотность употребления данных глаголов очень высока, это так называемые ядерные глаголы. Они свободно могут употребляться в других значениях, также у них отсутствуют стилистические ограничения в употреблении. Итак, наиболее часто употребляемыми глаголами восприятия в английском языке являются глаголы:

1) Зрительный канал- Look, see, glance, recognize, notice

2) Слуховой канал- hear, listen 
3) Обонятельный канал- smell, feel

4) Вкусовой канал- taste, feel, try

5) Канал осязания- feel, sense, push

Надо отметить, что такой глагол как "feel" может употребляться в разных коннотациях и свободно функционировать в разных каналах, например:

"The car was overheated and smelled of stale takeaways. I began to feel nauseous." [12;32]

В данном примере мы видим что глагол “feel" имеет коннотацию вкусового восприятия, в то время как второй пример выражает осязание кожей, в его прямом значении:

"When I got beneath the shower, the water felt like a hail of sharp gravel being hurled at my tender skin".[11;41]

Глагол “feel" может означать речемыслительную деятельность, например:

"But I felt I had no right to mind about the girl and that I didn't make any difference anyway." [11;39]

или выражать эмотивность:

"Late in the day we dotted the final "I" and crossed the final " $\mathrm{t"}$, and even though I was wrecked I felt light and happy." [11;6]

Однако, он не перестает быть глаголом восприятия, хотя как видно из примеров многозначен.

Глаголы зрительного восприятия составляют примерно 80 процентов от всех глаголов восприятия, это связано с тем, что зрение является одной из ведущих каналов взаимодействия с внешним миром. Зрительная система намного сложнее. Она больше, в ней участвует почти треть мозга. И хотя электрические сигналы в мозге распространяются с одной скоростью, зрительные сигналы обрабатываются сложнее и на это теряется время.

Изучая современные художественные англоязычные тексты, глаголы зрительного восприятия встречаются намного чаще остальных глаголов.

\section{Например:}

"The doctor stared at her for a moment, then blinked, glanced down and shuffled his papers. Clearing his throat, he said, 'Don't mention it. I can see that you are a nice family, who've hit a bad patch in your lives'. He looked up again and smiled, once more in control of himself. 'I hope you're right and that your father returns for you very soon. 'He glanced towards Sarah. 'Perhaps by then he'll have become a father again. In the meantime, we'll take good care of you all'.[10;65]

Из приведенных примеров можно сделать вывод что, глаголы восприятия многозначны и передают некоторые смысловые особенности других лексических единиц.

$$
\text { *** }
$$

1. Апресян Ю.Д.- « Лексическая семантика»Изд. «Восточная литература» PAН, 1995.-VIII с., 472 c.

2. Дмитриева Е.Г, Сафонова И.А, -« Глаголы восприятия и эмоций в древнерусском языке vs тексте: функционально- семантическая характеристика», Вестник Волгоградского государственного университета. Сер. 2, Языкозн. 2015. № 4 (28)

3. Козюра Т.Н.- «Залоговые значения глаголов зрительного восприятия (на материале русского и французского языков», Вестник ВГУ, серия: Лингвистика и межкультурная коммуникация, 2007, № 2 , Ч. 1

4. Кузнецова С.С.- «Базовые глаголы восприятия в речи диалектной языковой личности», Вестник Томского государственного университета. 2014. № 385. С. 16-23

5. Моисеева С.А. «Семантическое поле глаголов восприятия в западно - романских языках», монография, белгород,2005

6. Петрова И.П. « Категоризация мира соматическими фразовыми глаголами лексико- семантической группы восприятия», Вестник ИГЛУ,2012 
7. Слепцова Л.А «Синонимия глаголов со значением «восприятие» как отражение языковой картины мира (на материала синонимических словарей русского и английского языков» Известия Российского государственного педагогического университета им. А.И. Герцена,№60, 2008

8. Фатхутдинова В.Г.- «Деривационная динамика слухового восприятия» Вестник Нижегородского университета им. Н.И. Лобачевского, 2010, № 4 (2), с. 759-762

9. Чумакова Г.В. «О некоторых сложностях восприятия видовременных форм русского глагола в англоязычной аудитории», Вестник ТГГПУ. 2009. №1(16)

10. Margaret Dickinson- "Without sin”,London, Pan books,2005,436p

11. Marian Keyes - “Angels", London,Penguin books,2002,482 p.

12. Robert Harris “The Ghost”,London, Arrow books,2008,400p 


\section{JUURNAL_RU}

Научное издание

\section{Наука России: Цели и задачи}

Сборник научных трудов, по материалам

IV международной научно-практической конференции

10 августа 2017 г.

Часть 1

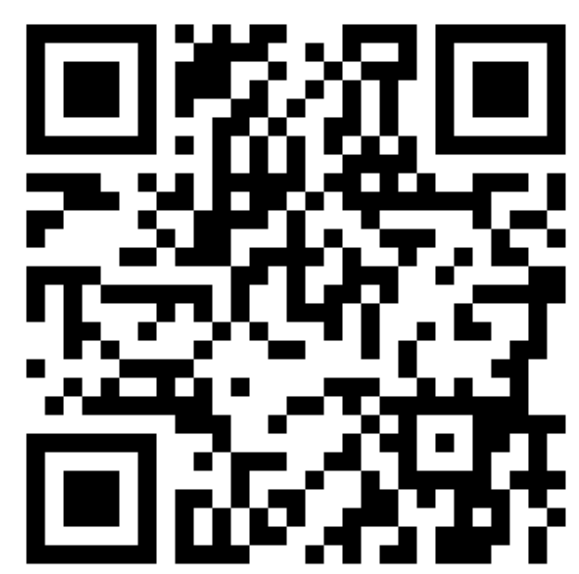

SPLN 001-000001-0171-SR

Подписано в печать 19.08.2017. Тираж 400 экз.

Формат.60х841/16. Объем уч.-изд. л.3,9

Бумага офсетная. Печать оперативная.

Отпечатано в типографии НИЦ «Л-Журнал»

Главный редактор: Иванов Владислав Вячеславович 